\title{
Contribuiçōes à Teoria da Genética em Populações
}

\author{
PROF. F. G. BRIEGER
}

Seç̧o de Genética da. F. S. A. "Luiz de Quelroz"

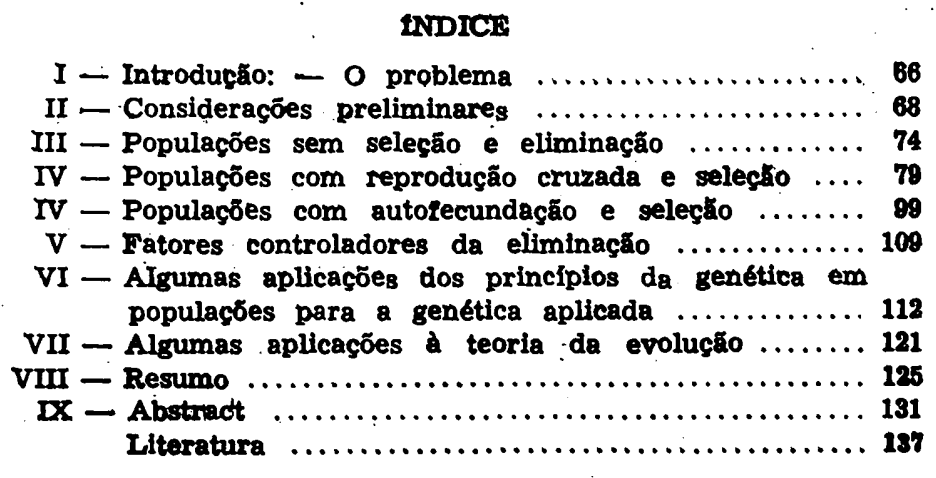

- Recebido para publicaçăo em 2-8-948. 


\section{I - INTRODUÇAO : - O PROBLEMA}

A genética em populações é um ramo da genética que está ganhando cada vez mais importancia, especialmente com relação aos problemas da genética aplicada, seja vegetal, animal ou humana, como também em relação ao problema fundamental da evoluçáo.

O princípio básico da descoberta de Mendel consistia em estudar rigorasamente individuos cuja antecedencia e descendencia eram.conhecidas, limitando-se ainda aas mais simples contrastes alternativas nos caracteres de individuas cruzadas.

$\mathrm{Na}$ genética das populaçoes nem um nem outro dêstes critérios pode ser respeitado. Em vez de conhecer as antepassadas de cada individuo, conhecemos apenas o conjunto de antepassados e sabemos qual é o processo de reproduçáo, se autofecundação, cruzamento livre ou combinaçăo de ambos estes processos. As caracteristicas que distinguem os individuos também năo săo em geral simples diferenças qualitativas e alternativas, mas ao contrário diferenças gradativas e quantitativas.

Queremos por exemplo selecionar individuos mais resistentes a doenças ou pragas, mais precoces, mais produtivos, etc. thstes caracterísiticos năo são devidos à ação fisiológica de simples pares de gens aleles, mas à interaçăo de um número grande de fatores mendelianos. Quando aplicamos o método ortodoxo, chamado "pedigree", mantendo separadas as descendencias de cada individuo, derivando dêles uma ou mais linhas, podemos evidentemente aplicar os métodas da genética comum. Mas este método tem a inconveniencia de podermos estudar apenas a descendéncia de relativamente poucos individuas, pois ao contrário o espaço necessário e o volume de trabalho tornar-se-iam excessivos. Esta limitação a poucos indivíduas pode, por sua vez, causar graves prejuizos, pois nåo sabemos no início quais os individuos que sáo portadores das melhores combinaçóes de gens. $O$ perigo da perda de material de grande valor potencial que assim corremas; será menor quando trabalhamas com populaçzes. Isto năo quer dizer que devemas voltar aos processos antigas da seleção massal ou do

(*) Os principais resultados dêste tribalho já foram apresentados no Congresso da. Sociedade de Biologia, em Setembro de 1947, em Belo Horizonte. 
melhoramento "empirico". Evidentemente os processas massais tornam-se muito ineficientes, se aplicados sem as conhecimentas básicos sôbre a transmissão hereditária em populações mistas e compastas de individuos de constituiçăo e viabilldade variada.

Um estudo das regras da genética em populaçóes poderá resolver a antiga disputa entre as chamados "melhoristas" e as geneticistas. Parece-me bastante evidente que os métodos massais, aplicados empiricamente e năo cientificamente năo são de modo algum eficientes. Citaremas um exemplo concreto. Os "farmers" clentlficamente náo trelnados, produziram nos Estados Unidas durante o século passado as principais variedades do milho dente norte-americano, o "Reid's Yellow Dent", o "Lancaster Surcropper" dos Hersching e "Krug-Dent" (Anderson 193 ). Mas năo devemas esquecer que no caso das duas primeiras variedades, duas geraçōes de "farmers", pal e fllho, trabalharam durante longos anas ate obter o resultado final e que simultaneamente centenas de outras "farmers" aplicaram os mesmos processos da "seleção massal intuitiva", sem obter resultados apreciáveis. Se fósse possivel calcular exatamente o tempo e as trabalhos gastos em dólares durante o século passado com êstes trabalhos, o preço das poucas variedades, finalmente reconhecidas como melhores, ficaria extremamente alto e pouco compensador.

As conclusões obtidas pelos métodos da genética clássica sắo muito apreciávels: sabemos como novas caracteres hereditários podem apareoer e até certo ponto, como mutações genicas podem ser provocados em experimentas controlados. Mas náo está ainda bem explicado como os novos tipos podem fixar-se na natureza, năo sòmente mantendo-se na luta da vida, mas ao contrário eliminando as tipos originais anteriores. A importancia dêste problema é bem evidente nos trabalhos numerosos de um dos mais destacados especialistas contemporaneos, Th. Dobzhansky.

A literatura sôbre as regras básicas da genética em populaçăo năo é multo grande, e ainda é relativamente espalhada.

A situaçáo em plantas que se reproduzem por autofecundaçáa fol discutida e estudada quando se procurava a justificaçăo cientifica do método de melhoramento, denominado "inbreeding and outbreeding" (East and Jones, 1918).

A regra básica sobre populações com reprodução cruzada, e sem eliminação, é geralmente citada como o teorema de Hardy-Weinberg. (Veja o resumo histórico de Stern 19). 
O estudo da genética em populaçóes com referencia especíal ao problema da evoluçáo em organismos com reproduçáo cruzada, desenvolveu-se lentamente por trabalhas de Fisher, Haldane, S. Wright e outros, e as resultados da análise matemática estáos resumidas em S. Wright (1939) e L. Hogben (1946).

A finalidade inicial dos nossas estudos sobre o assunto era a justificaçáo cientifica de um novo método do melhoramento do milho que chamo o "método das populaçes balançadas". As fórmulas idealizadas e os cálculos feitos deram resultadas que permitiram aumentar consideràvelmente o número de problemas e tirar conclusoes bem mais gerais do que eram esperadas inicialmente. $O$ objeto do presente trabalho é assim dar a derivaçáo de um sistema de fórmulas matemáticas que darăo resposta aos principals problemas da genética em populaçóes e tirar conclusరes sôbre problemas de genética aplicada e de evoluçáo.

Uma discussáo detalhada da literatura e a comparaçăo das formulas novas dadas com as fórmulas de outros autores, ficarăo reservadas para uma publicaçåo futura.

\section{II - CONSIDERAÇOES PRELIMINARES}

\section{1) Métodos de reprodução:}

Temas que distinguir dois tipos extremos da reproduçáo diversa: reproduçáo cruzada e autofecundaçăo.

$\mathrm{Na}$ reprodução cruzada supomos que todos as individuos de uma população cruzam-se livremente entre si. Isto acontece em muitas populaçбes de animais quando năo haja qualquer preferência de machos ou fêmeas ao se acasalarem. Fm plantas dibicas, como o mamoeiro ou o pinheiro, podemos supor que o polem seja levado indiscriminadamente, por animais ou pelo vento, de qualquer planta feminina. Em plantas hermafroditas como o milho, a reproduçáo cruzada inclul automáticamente uma certa porcentagem de autofecundaçăo. Se nós temas por exemplo um campo de mil individuos que florescem simultaneamente e supomas que o polem saindo das anteras se mistura livremente, esta mistura será distribuida pelas correntes de ar sobre todas as barbas. Quando uma determinada planta recebe esta mistura do pólem das mil individuos, ela será autofecundada na proporçăo de um por mil oosferas fertilizadas.

$\mathrm{Na}$ natureza encontraremos apenas raramente êste caso 
realizado na sua forma ideal, e podemas verificar muitas complicaçoes devidas a processas seletivas e eliminativas. Numa populaçáo de plantas de milho existira uma preferencia das individuos receberem o pólem de plantas vizinhas, e uma distribuiçăo 20 acaso das indivíduas de constituiçăo diferente poderá compensar o efeito da polinizaçăo preferencial entre v1sinhas. Se as mariposas escolhessem plantas diferentes de mamăo, de acordo com o perfume ou a cor das flores, esta seleçáo afetaria profundamente a situaçá e o cruzamento năo seria mais livre. Se em animais houvesse preferencia no acasalamento, fenómeno -esse já experimentalmente comprovado, isto também causaria complicaçóes sendo o cruzamento nåo mais completamente livre.

O segundo tipo de reprodução em populaçoes e a autofecundação obrigatória. Uma aproximaçăo a esta situaçăo encontramas em muitas espécies de plantas, como o trigo, fumo, fejja, etc. nos quais a frequencia de autofecundaçáo é entre 95 e 100 . Em animais, onde uma autofecundação é impassivel, - cruzamento entre iımáas dará, essencialmente, um resultado correspondente.

Em plantas devemos ainda incluir um terceiro caso, intermediário entre os primeiros. Em mamona e em café por exemplo, fol constatado que autof ecundaçăo e cruzamento l1vre săo mais ou menos igualmente prováveis. Assim; num lote de mil plantas cada flór nåo será autofecundada uma vez pala 999 cruzamentos, mas terá 50 flores autofecundadas para cada 50 flores cruzadas. (Gurgel 1945, Krug, Mather 1947).

2) Processos de eliminação :

Um número bastante grande de processos biológicas pode causar uma seleçáo em favor de alguns e em prejulzo de outros genotipos, alterando assim o equilibrio final.

Do ponto de vista do tratamento matemático é apenas necessário na maioria dos casos, distinguir entre duas formas de eliminação: ellminaçăo durante a fase vegetativa e durante a fase reprodutiva.

A eliminação na fase vegetativa pode ser constatada nas primeiras fases do desenvolvimento ontogenético: pelo aborto de embribes em animais ou plantas, pela falta de desenvolvimento além do estado larval ou pela falta de germinaçăo, ou finalmente durante qualquer outra fase pasterior do desenvolvimento. $O$ número de tipos de eliminaçăo vegetativa é tăo 
grande de modo que nåo me parece necessário dar aqui quaisquer citaçōes ou referencias bibliográficas.

Os processos biológicos de uma eliminação na fase reprodutiva săo om grande parte bastante diferentes em animais e em plantas.

Devemos fazer referencia em animais a dois processas. São conhecidas hoje numerosos casas de acasalamento e inseminatho preferencial sendo que as espécies e raças de Drosophila representam hoje o material melhor analizado (referência a literatura em Patterson 1947, Levene e Dobzhansky de determinados genótipas. Ambas estes processos dão resultado que sáo identicos para as nassos fins. Supomos que temas em estudo uma mistura de femeas de duas raças A e B, com a presença de machos apenas da raça A. Tanto um acasalamento preferencial entre femeas e machos da raça A, como uma redução da fertilidade das femeas $B$, darăo o mesmo resultado: uma reduçáo da frequencia dos hibridos (AB).

Em plantas superiores temos de levar em consideração, além de uma reduçáo da fertilidade, o efeito das chamados fatores gametofíticos que foram especialmente estudados em milho (veja literatura em Brieger 1943). Uma competiçăo entre megasporios ou entre tubos polínicos reduz o número de células sexuais que conseguem executar a sua função e produzir zigotos do mesmo modo como esterilidade. Os fatores para auto-esterilidade que causam em numerosos casos também $r$ terilidade de determinados cruzamentos, agem até certo ponto como 0 acasalamento preferencial de animais.

Fizemos até agora apenas referencias aos processos que atuam na natureza e que podem $t \leqslant r$ o seu efeito na seleçăo natural. O resultado de uma seleçáo dirigida pelo homem não difere, seja na eliminação antes da fase reprodutiva de tipos não desejados, seja na sua exclusão na fase reprodutiva, por qualquer castração.

Os efeitos da eliminação podem ser completos ou parciais, e devemos introduzir, para o uso nas formulas um têrmo que nos permita avaliar quantitativamente os seus efeitos. Usámos para isso o indice de sobrevivéncla que nos indica a frequência dos individuos restantes, depois da eliminação seja na fase vegetativa, seja na fase reprodutiva. A maioria dos autores preferiam tomar em conta a fraçáo de individuos eliminados por qualquer processo seletivo, fraçáo esta designada pelo simbolo $K$ por Haldane e pelo simblo $S$ por Wright Porém acho preferivel empregar ao contrário a frequéncia de individuos ou de células sexuais que restam ainda depois de eliminaçáo, usando a letra $\mathbf{R}$. 
Em populações de um só genótipo, podemas determinar as frações de indivíduos sobreviventes diretamente por contagem. Quando porém a população é composta de diversos genótipos; exprimimos em geral as sobrevivências em relação a um dêles: Assim, em populações heterozigotas para um par de gens, contendo os trés genótipos AA, Aa e aa, muito comum determinar a viabilidade em relação aos homozigotos "normais" ou "wild type" (por exemplo Wright 1939). Parém isto dá fórmulas assimétricas, e porisso parece-nos melhor determinar a sobrevivência dos do:s homozigotos em relação aos heterozigotos Haldane 1926, Wright 1947, Brieger 1948). Voltaremos a este ponto ainda mais tarde.

Também náo é de se esperar que os valores $R$ sejam sempre constantes. A sobrevivência é na última análise um característico resultante de processos fisiológicas, e assim depende de numerosos fatores externos, como da temperatura, etc. Ela também pode variar de fração do número de individuos de constituição diferente que entrem em competição.

Quando há eliminação' vegetativa e reprodutiva, 'é necessário distinguir as frações correspondentes da sobrevivência glabal R, pelós sufixos V e R :

Assim temos :

Sobrevivência vegetativa $\quad: \quad:$ RV

Sobrevivência reprodutiva : $\mathbf{R R}$

Sobrevivência global : $\mathbf{R}$

sendo $\quad \mathbf{R V} . \mathbf{R R}=\mathbf{R}$

3) Princípios e finalidades das fórmulas :

A análise matemática das mudanças que podemas observar em populações visa o segulnte :

a) determinar qual a frequencia dos diferentes gens no equilibrio final da população.

b) estudar a alteração das frequências de geração em geração.

Nas formulas temos que distinguir duas fases : a composiçáo da população inicial e o equilíbrio final que será atingido com um dos tres sistemas de reprodução distinguidos no capitulo anterior, e tomando em consideração ainda as efeltos de processos seletivas, se houver. As formulas devem permitir a construção de curvas para determinar as alteraçбes das frequencias em geraçós seguidas até atingir o equilíbrio final. 
A resolução do primeiro e do último problema mencionadas acima é relativamente fácil, mas a determinaçáo do número de geraçðes necessárias para atingir o equilíbrio é um problema - muito dificil de ser solucionado. Em certas casos, os autores aplicaram as prócessos do cálculo diferencial $\theta$ integral : para esse fim. Este processo parece-nos sòmente admissivel quando o numero total de geraçбes necessário para atingir o equilibrio for tho grande que as mudanças em cada geraçăo serăo suficientemente pequenas para que os processos de diferenciaçăo sejam permissiveis. Mas discutiremos numerasas casas onde menos do que 15 gerações já săo o suficiente. Podemos também idealizar outras fórmulas, empregando diretamente os principios de séries matemáticas. Mas a sua aplicaçáo só é passivel quando pudermos desprezar todas as potencias superiores por serem de dimensóes muito pequenas, e isso acontece apenas quando as frequencias iniciais das genótipas ou gens såo bastante baixạs.

Podemos determinar o número de geraçбes necessárias para atingir o equilibrio pela interpolaçáo gráfica de curvas, calculadas ponto a ponto, durante um certo intervalo. Istas curvas aproximam-se assintoticamente ao nivel do equilíbrio, e assim será mais uma questão de julgamento subjetivo, matemático ou istatístico, quando consideramas a aproximaçáo suficiente para dizer que o equilíbrio fol pràticamente atingido.

A taxa de alteração das frequências dos diferentes tipos hereditárias por geraçăo é uma quantidade descontínua, e năo temas na realidade uma mudança contínua que passa ser apresentada por uma curva, mas sim saltos que deveríamos representar por um histograma. Matematicamente o emprego de curvas seria apenas justificado quando o número de geraçōes, isto é, de pontos nas llustraçбes gráficas, fôsse muito grande e assim as distancias das abcissas seriam muito pequenas. Mas a representaçáco por curvas năo sómente é mais fácll tècnicamente, mas além disso mastra multo melhor a lenta aproximaçåo ao equilibrio final, de modo que preferimas este sistema de representaçăo.

Temas finalmente que mencionar uma convenção genética. Como já fol explicado acima, trata-se em geral na genética em populaçáo de diferenças causadas por várias pares de gens que afetam em confunto as caracteres dos componentes das populaçoes. Para simplificar as fórmulas e mostrar as regras gerals e básicas, faremos referencia apenas a segregaçóes monofatoriais, nas quais tres genotipas podem ser distinguidos: os dois homozigotos AA e aa e os heterozdgotos Aa. 
Uma vez estabelecidas as regras básicas para populações com segregaçóes monofatoriais, é fácil chegar às generalizaçбes para segregaçós polifatoriais, aplicando os principios da multiplicaçăo de frequéncias. Quando se trata de gens genèticamente ligados, temas que calcular as frequencias gaméticas. Mas uma vez que se trata apenas de processos bem conhecidos e básicas na genética mendeliana clássica, acho desnecessário entrar em mais detalhes.

\section{4) Flutuação seletiva (genetic drift)}

Devemos ainda mencionar aqui mais um ponto importante no estudo das populaçós. As leis e regras podem ser aplicadas apenas em "populaçóes" no sentido estatistico déste têrmo, isto é, em conjuntas muito numerasos de individuas $\mathrm{Fm}$ populaçбes de tamanho limitado ou em amostras pequenas, uma complicaçăo pode entrar em ação que S. Wright chama de "genetic drift", o que nós podemos traduzir como flutuaçåo ou ascilaçăo seletiva.

Supomas que esperamas numa geraçăo qualquer $p$ individuos de um determinado genótipo. $O$ número atual esperado em $\mathbf{N}$ individuos será entåo igual a p. N., com um erro standard, Igual a $\pm p(1-p) N$. $O$ valor (p.N) observado será em geral diferente do valor esperado, de acordo com as leis de variação de acaso, e um desvio relativamente grande será em geral compensado nas geraçbes seguintes por variaçбes em sentido opasto. Insta compensaçăo torna-se impossivel apenas num caso: quando a variaçáo do acaso causa um desvio tal que o valor (N.p) torna-se igual a zero, o que significa a eliminaçáo definitiva do respectivo tipo-da populaçăo.

Insta complicaçáo do desaparecimento total de certas genótipas podemos "a priori" evitar, se escolhermas o valor de individuas $\mathbf{N}$ de tal modo que passamos esperar pelo menos um individuo de cada genótipo, usando para isso as fórmulas dadas em outro lugar Brieger 1947. Entretanto, do ponto de vista prático, nem sempre será passivel empregar um número bastante grande de individuos. 


\section{III - POPULAÇOESS SEM SELEÇAO E ELIMINAÇĀO}

\section{1 - Populações de reprodução cruzada.}

Para facilitar a compreensão do processo empregado para derivar as fórmulas, iniciaremos a discussão com um caso especial e simples, no qual a populaçăo inicial é composta sòmente de individuos heterozigotos. Aa. Cada um déles produz células sexuais da constituição a e $\mathbf{A}$, em númeras iguais, de modo que a populaçáo em conjunto produz $50 \%$ de células sexuais em ambos as sexos, com a constituiçáo $\mathbf{A}$, e outras $50 \%$ da constituiçăo a. Astes gametas, combinando-se livremente, darăo na primeira geraçăo $25 \%$ de individuos AA, 50\% de heterozigotos Aa e 25\% de outro tipo homozigoto aa. Agora teremos, na formação das células sexuais do tipo A, 25\% provenientes dos homozigotos AA, e mais 25\% provenientes dos heterozigotos Aa. Igualmente teremos $25 \%$ células sexuais da constituiçáo a provenientes dos homozigotos aa e mais $25 \%$ provenientes dos heterozigotos. Assim o conjunto de células sexuais da primeira geração será de $50 \%$ A e de $50 \%$ a, dando na segunda geraçáo da população novamente $25 \%$ AA $+50 \%$ Aa $+25 \%$ aa: Podemas concluir que o equilíbrio da populaçăo já é atingido na primeira geraçåo e se mantém inalterado em tôdas as geraçoes posteriores.

Passamos agora para o caso geral, onde os três genótipos sâo representados na populaçáo inicial com as frequências relativas de $u, v$ e $w$ sendo a soma destas tres frequências igual a um. Como podemas vêr no esquema abaixo, a frequéncia de células sexuais do tipo A será igual a $(u+v / 2)$ e do tipo a $(\mathrm{v} / 2+\mathrm{w})$. Aplicando o teorema da multiplicaça de frequenclas ou probabilidade, podemos fảcilmente determinar as frequências dos três genótipos na primeira geração, como se vê no esquema. A proporção de células sexuais produzfda pela primeira geraçăo é igual áquela da populaçăo inicial, isto é; que já chegamos ao equilíbrio.

Se usarmas para a indicação das frequências dos gametas na populaçáo em equilíbrio as letras $\mathbf{p}$ e q, nossas fórmulas tornam-se identicas ao chamado teorema de Hardy-Weinberg. Mas acho preferivel manter as letras $u, v$, e $w$ para explicar claramente a relaçăo entre a populaçăo inicial e a populaçăo equilibrada, e também para mostrar que o equilibrio é imediatamente atingido sejam quais forem as frequencias iniciais $u$, $v$ e w das tres genotipos. 


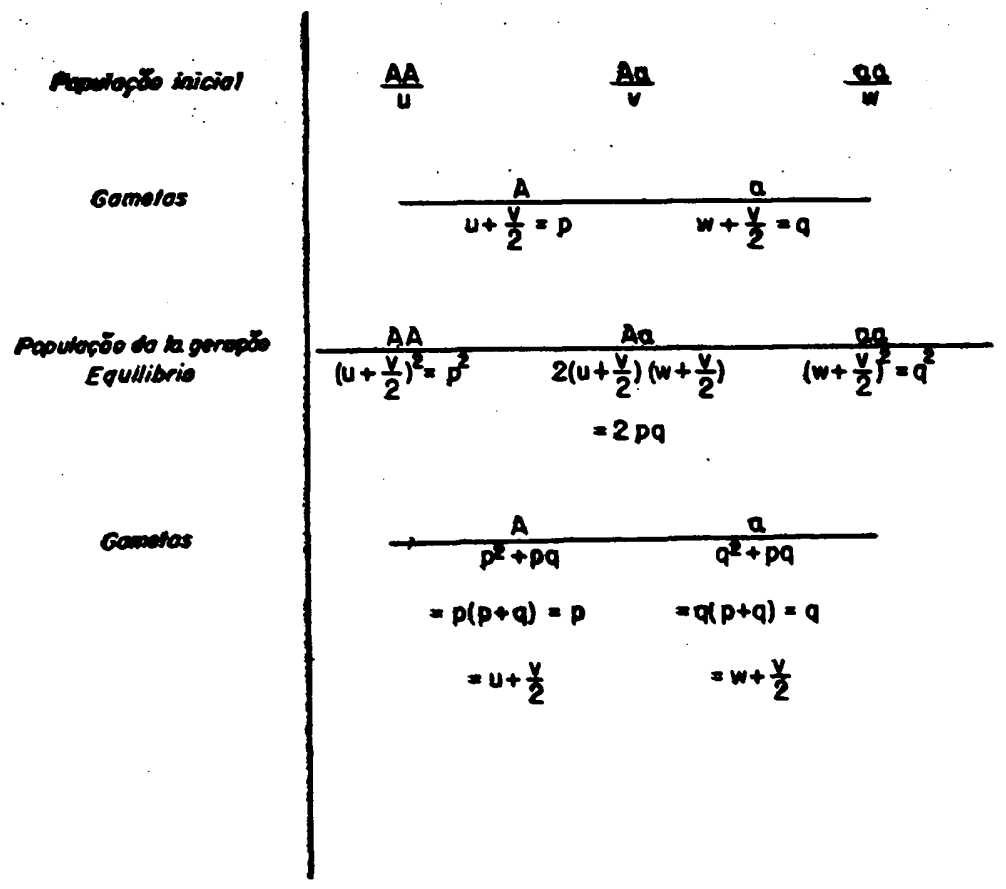

Conclusão : Em populaçర̄es com reproduçăo cruzada e sem qualquer processo eliminativo, partindo de uma populaçăo Iniclal, com qualquer proporçáo das genótlpos, obteremos, logo na primeira geraçăo já uma condiçăo equilibrada na qual a frequencila de gametas de um ou outro tipo (A ou a) é igual a frequencla das respectivas homozigotos na populaçáo inicial pela metade da frequencia dos heterozigotos.

\section{2) Populações com autofecundação obrigatbria :}

Iniciaremas, como no capitulo anterior, a discussăo com um caso especial, supondo de novo que a populaçăo inicial seja composta apenas de heterozigotos monofatorials da constitulçăo Aa. Na primeira geraçăo teremas então, de acôrdo com a primeira lel de Mendel, a proporçáo de um quarto de cada homozigoto para do's quartos de heterozigotos. $\mathrm{Em}$ cada geraçăo pasterior será sempre acrescentado a cada um dos homozigo- 
tos, um quarto da frequencia das heterozigotos, de modo que a frequencia dos heterozigotos diminul cada vez pela metade. Como se pode vêr pelo esquema abaixo, podemos dar as frequenclas dos tres genotipos em geraçóes seguidas na forma de funçбes exponenciais do número 2.

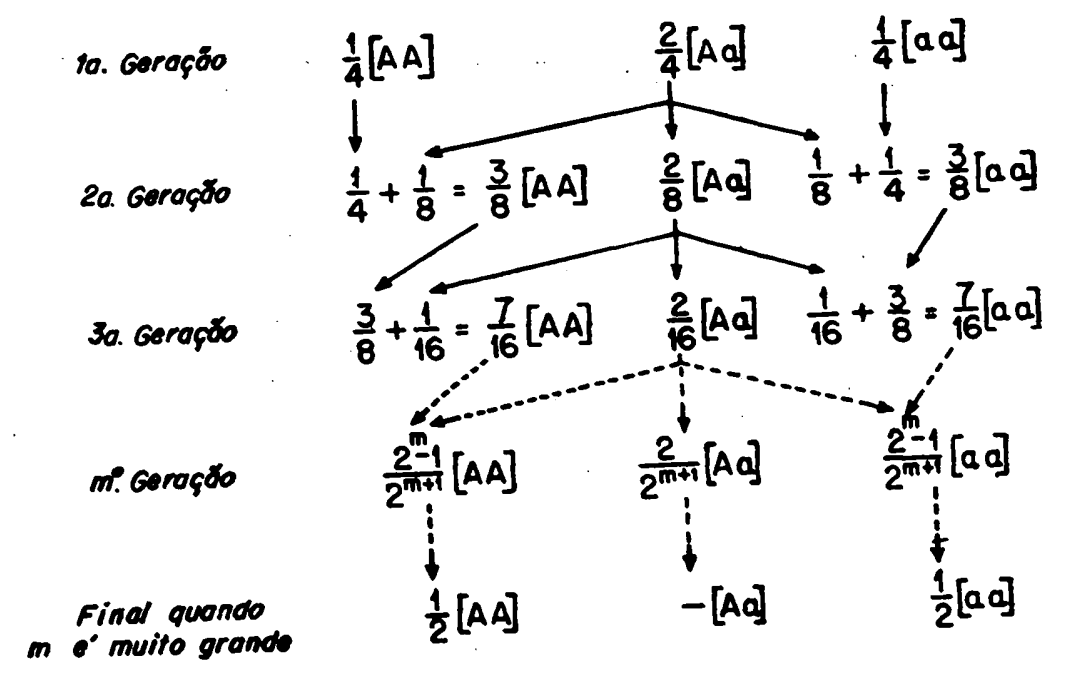

Se continuarmos a autofecundaçăo durante um número de geraçōes muito grande, o valor dos expoentes cresce de tal modo que a frequencia dos heterozigotos torna-se infinitamente pequena. No dividendo das frequencias dos homozigotas podemos desprezar o valor um, que torna-se multo pequeno em relaçåo ao valor da potencia de 2 , e assim o valor desta frequência fica igual a $1 / 2$.

Passaremas agora a discutir o caso geral, onde a populaçáo Inicial será compasta dos tres genótipas na frequencia $u+\nabla+w=1$. Como se ve pelo esquema abaixo, a marcha da mudança das frequencias é, essencialmente, a mesma que no caso anterior. 


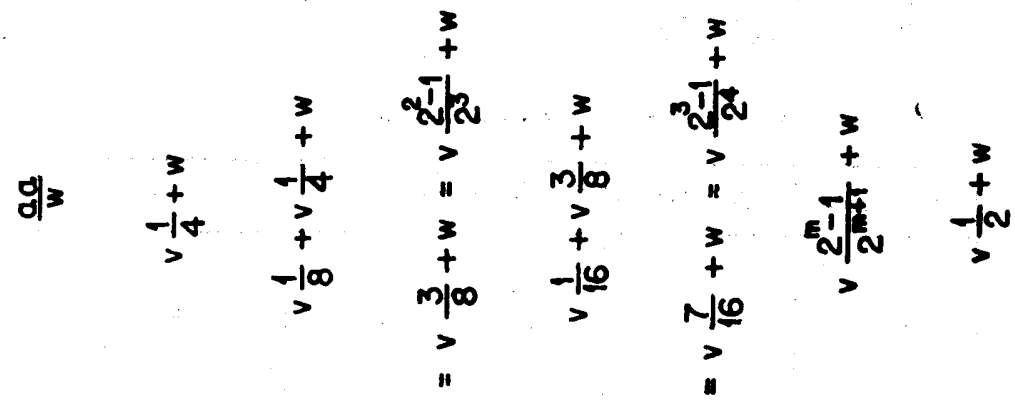

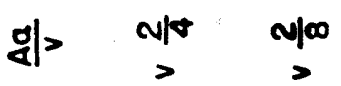

$\underset{>}{N \mathscr{Q}}$

N展

mất

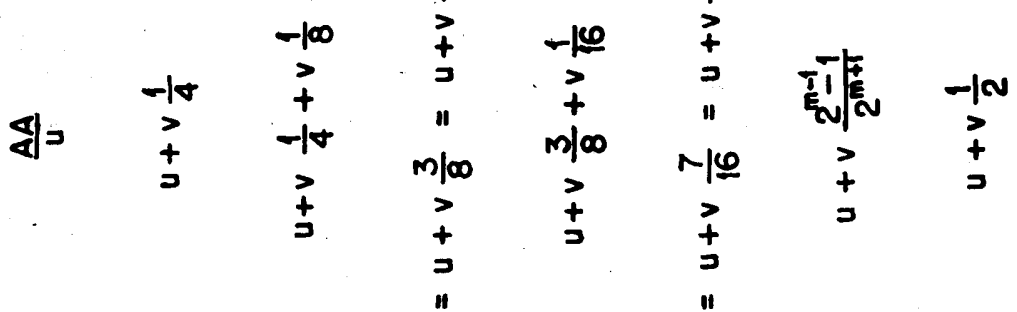

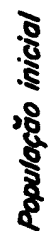

$\begin{array}{ll}3 & 8 \\ 8 & 8 \\ 8 & 8 \\ 0 & 8\end{array}$

3
8
8
8
in

हू
है
है

: 
Depende dos valores relativos de $u, v$ e $w$, quando podemas considerar as frequencias dos heterozigotos como suficientemente pequenas para torná-las iguais ao valor zero. As frequencias finais dos genótipas são mais uma vez resumidas no esquema seguinte.

\section{Frequêncio}

\begin{tabular}{|c|c|c|c|}
\hline Genotipo & Inicial & $m^{\circ}$ Geroģöo & Final \\
\hline AA & $u$ & $u+\frac{2^{m}+1}{2^{m+1}} v$ & $u+\frac{1}{2} v$ \\
Ao & $v$ & $\frac{2}{2^{m+1}} v$ & - \\
o o & $w$ & $w+\frac{2^{m}-1}{2^{m+1}} v$ & $w+\frac{1}{2} v$ \\
\hline
\end{tabular}

Podemas zonstatar que não há um equilibrio completo, final, do ponto de vista matemát:co, pois em tôda geração nova temas uma diminuiçáo das frequéncias dos heterozigotas pela metade. Mas a frequencia total dos heterozigotos torna-se sempre finalmente tăo pequena que se atingirá pràticamente um equilibrio no qual estarăo presentes apenas as duas formas homozigotas.

Conclusão : Em populaçźes com autofecundação obrigatória năo existe, matemàticamente, equilíbrio final, mas pràticamente a frequência dos heterozigotos aproxima-se ao valor zero, e as dos dols homozigotos se aproximam finalmente a valores que são iguais às suas frequências na população inicial mais a metade da frequência inicial dos heterozigotos.

\section{3) Populações com reprodução mista:}

Em populaçóes ondie os individuos se reproduzem tanto por autofecundação e por cruzamento, a situação torna-se complicada, pois temas que tomar em consideração duas tendencias opostas: o cruzamento livre tende para o estabelecimento imediato de um equilíbrio entre os três genótipos, enquanto a autofecundação causa uma eliminação lenta, mas, f1- 
nalmente, quase completa das heterozigotos. Podeliamos explicar a situaçáo por fórmulas matemáticas, porém estas são muito complexas, e por isso limitar-nos-emos a dar apenas a soluçáo final em alguns casos, isto é, os valores do equilibrio para o qual as frequências tendem em população de reproduçáo mista, partindo de uma população inicial compasta unicamente de heterozigotos Aa.

Podemas tirar as seguintes conclusões das dados que constam no Quadro 1.

Quando a reproduçåo cruzada ocorre nove vezes mais frequentemente do que a autofecundação, obteremos um equilíbrio já na terceira geraçăo com cêrca de $26 \%$ para cada homozigoto e cerca de $47 \%$ para os heterozigotos. Na situação inversa, sendo a autofecundaçáo nove vezes mais frequente do que o cruzamento livre, chegaremos praticamente a um equilíbrio na décima terceira geraçáo, sobrando apenas $10 \%$ de heterozigotos ao lado de $45 \%$ de cada homozigoto. Quando as dois processas de reproduçăo săo igualmente provávels, o equilibrio será aproximadamente atingido na oitava geraçăo, com frequencia igual para as tres genótipas, cada um com um valor de $33 \%$.

Conclusăo: Em populaçóes de reproduçăo mista se estabelece aproximadamente um equilibrio, depols de um certo número de geraçбes dependendo este número de geraçбes da frequencia nelativa do cruzamento livre ou da autofecundaçáo dos individuos.

\section{IV - POPULACOES COM REPRODUÇAO CRUZACAA}

\section{E SELEÇAO}

\section{1) Considerações gerais :}

Para simplificar as discussoes, faremas apenas como no capitulo anterior, referencias à populaçôes com segregaçăo monofatorial, e precisamas apenas definir melhor a sobrevivencia de dois homozigotas e dos heterozigotos. As formulas se tornam simples se empregarmas apenas dois indices, exprimindo a sobrevivencia dos dois homozigotos em relação as heterozigotos.

Supomas que a sobrevivência dos tres genótipos corresponde aas valores $x$, y e $z$. Dividindo a proporçáo tripla déstes valores pelo valor de $y$, obtemos dols valores $R A$ e $\mathrm{Ra}$ da sobrevivencia dos homozigotos AA e aa, e em relaça a sobrevivencia dos heterozigotos que é igual a unidade. 


\section{Relasōes do Viabilidade \\ $x[A A]: y[A a]: z[a d$ \\ $=\frac{x}{y}[A A]: 1[A Q]: \frac{z}{y}[a d]$ \\ $=R_{A}[A A]: 1[A a]: R_{0}[a d$}

Os índices $R$ podem ter qualquer valor : desde zero, quando há eliminaça completa das respectivas homozigotos até infinito, quando a sobrevivencia de um dos homozigotos é infinitamente maior daquela das heterozigotos.

Indicamos a sobrevivencia global pela letra R, seja RA ou Ra. Devendo frequentemente distinguir a seleçáo vegetativa e reprodutiva, empregamos para a sobrevivencla vegetativa as letras: RAV e RaV é para a sobrevivencia reprodutiva RaR e RaR.

Os tres termas são ligados por uma simples relação algébrica, pois o produto da sobrevivencia vegetativa e reprodutiva deve ser igual, por definiçáa, ao valor da sobrevivencia total.

$$
\begin{aligned}
& R_{A V} \cdot R_{A R}=R_{A} \\
& R_{O V} \cdot R_{O R}=R_{0}
\end{aligned}
$$

Na discussáo seguinte trataremos em primeiro lugar das fórmulas em geral, para depois discutir quatro casas especiais: quando a sobrevivencia dos dols homozigotos é menor que a dos heterozigotos, quando a sobrevivencia de um dos homozi- 
gotos é malor e a do outro menor do que a dos heterozigotos, e quando a sobrevivencia de um dos homozigotos é igual e a do outro inferior a dos heterozigotos, e finalmente quando ambos as homozigotos tem maior sobrevivencia do que as heterozigotos.

Nestes quatro casas aceitamas que a eliminaçáo, quer seja vegetativa, reprodutiva ou mista, é igual nos dois sexas. Discutiremos também alguns exemplos dos casos mais interessantes de uma seleça diferente nas sexas.

\section{2) As fórmulas em geral :}

Focalizámas, em primeiro lugar, a questáo da determinaçá das frequencias dos tres genótipas na fase de equilíbrio.

Podemas fàcilmente derivar fórmulas para a frequencia dos dols tipas de gametas $A$ e a na fase de equilibrio, fazendo 0 seguinte raciocinio: $O$ equilíbrio é caracterizado pelo fato de que as proporçరes de gametas em geraçбes seguidas năo mudam mais, sendo ao contrário constantes e iguais. Assim basta calcular a trequencia dos gametas em duas geraçoes seguidas e considerando-as como iguais, para obter duas equaçoes, para as frequencias p e q dos gametas $\mathrm{A}$ e a, o que é matemàticamente suficiente para determinar estas duas incognitas. Conhecendo as frequencias iguais a $u, v$ e $w$, sendo a soma delas igual a um. A frequencia de gametas A e a é assim igual a frequencia das respectivos homozigotos mais a metade da frequencia dos heterozigotos. Denominamas estas frequenclas de po e qo. Calculamos agora as frequencias dos tres genótipas na próxima geração, tomando em consideração indices de sobrevivencia global. Achando os dois tipos de gametas para esta geraçáo, basta igualar as termos assim obtidos aas valores po e qo e solver as duas simples equaçoes, resultantes para po e qo. 


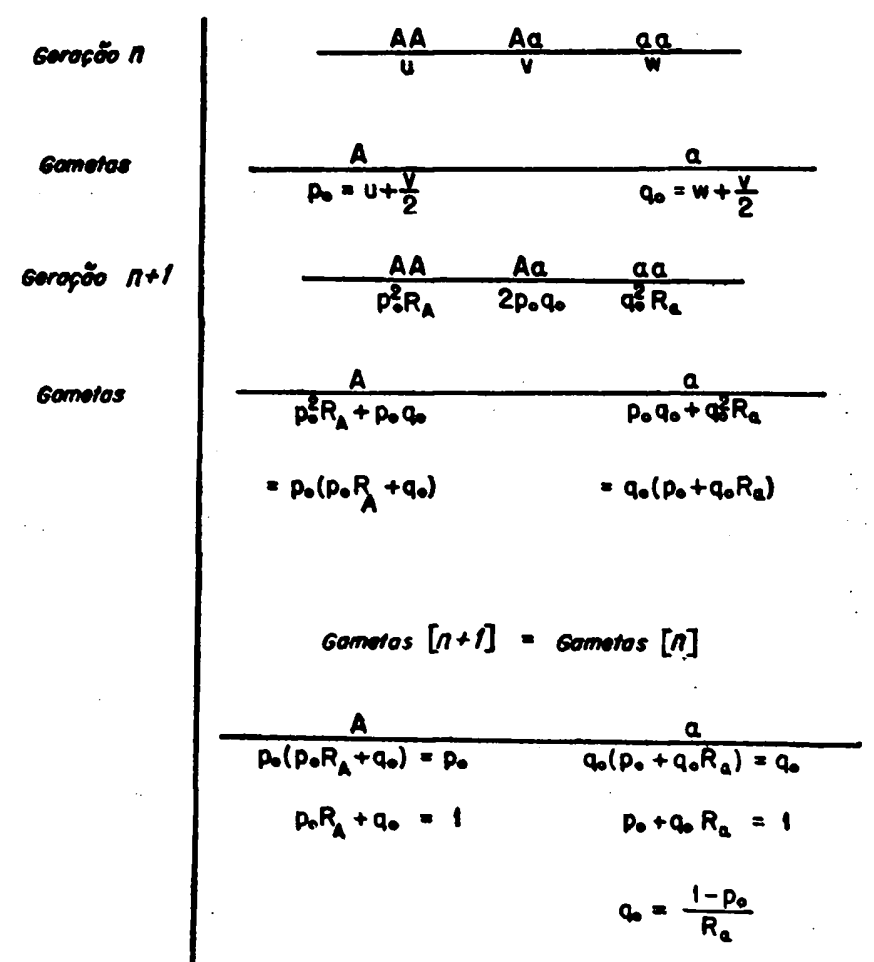

subortituindes of

$$
\begin{aligned}
& D_{0} R_{A}+\frac{1-P_{R}}{R_{B}}=1 \\
& D_{0}=\frac{1-R_{B}}{1-R_{A} R_{a}} \quad Q_{0}=\frac{1-R_{A}}{1-R_{A} R_{a}} \\
& \frac{R_{0}}{Q_{0}}=\frac{1-R_{a}}{1-R_{A}}=\frac{S_{a}}{S_{A}}
\end{aligned}
$$

Equillbrio $\left\{\begin{aligned} \frac{p_{0}}{p_{0}+q_{0}} & =\frac{1-R_{0}}{2-R_{A}-R_{0}} & \frac{q_{0}}{p_{0}+q_{0}} & =\frac{1-R_{A}}{2-R_{A}-R_{0}} \\ & =\frac{S_{Q}}{S_{A}+S_{0}} & & =\frac{S_{A}}{S_{A}+S_{0}}\end{aligned}\right.$ 
As fórmulas finais tanto para a proporçăo como para a frequencia dos dois tipas de gâmetas mostram que os valores po e qo sáo apenas funç⿸丆⿰丨丶㇀ dos valores de sobrevivencia global $R$, ou de eliminaçáo $\mathbf{S}$, năo tendo importancla alguma as valores parciais da sobrevivencia vegetativa ou reprodutiva, nzo entrando no cálculo as frequências $u, v e w$.

Partindo das fórmulas gaméticas é muito fácll calcular as frequencias dos três genótipos zigóticas para a fase do equilibrio

$$
\frac{p_{0}}{q_{0}}=\frac{1-R_{0}}{1-R_{A}}
$$

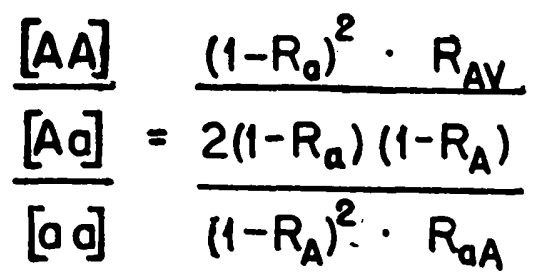

Os resultadas do cálculo para um número de combinaçóes de valores de $\mathbf{R}$ constam no Quadro 2.

Conclusão: Populações monofatoriais reproduzidas por cruzamento livre com eliminação de genótipos, atingem um equilibrio quando os dois tipos de gametas estão presentes em frequências inversamente proporcional aos valores da eliminação global. As frequências dos genótipos zigofásicos dependem ainda dos indices da sobrevivência vegetativa. As frequências iniciais dos genótipos são sem importancia alguma.

Para calcular as mudanças de geração a geração a partir da população inicial aplicamos o seguinte raciocínlo:

Supomas que a frequencia dos gametas na populaçáo inicial era igual a p para o gen $\mathrm{A}$, e igual a $\mathrm{q}$ para o gen a. Podemos fàcilmente deduzir a frequencia dos três genótipos na primeira geraçáo tomando em consideraçáo os valores da sobrevivencia global. Pelo mesmo processo podemos deduzir as frequências para tôdas gerações seguintes: Introduzimos apenas os termos t1, t2, etc. e $1_{1} 1_{2}$ etc., para facilitar a compreensão das fórmulas, como veremas na deduçáo que segue: 
84

Anais da E. S. A. "Luiz de Q.eirc?"

Froquincio no populogits inclate $P[A]+q[Q]=1$

1a. corogito

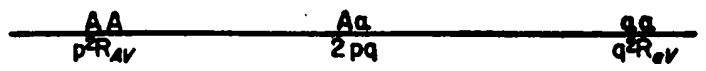

Gomotos

$$
\begin{array}{ll}
\frac{A}{p^{2} R_{A}+p q} & \frac{q}{p q+q^{2} R_{0}} \\
=p\left(p \cdot R_{A}+q\right) & =q\left(p+q R_{0}\right) \\
=p t_{1} & =q \cdot l_{1}
\end{array}
$$

encorogib

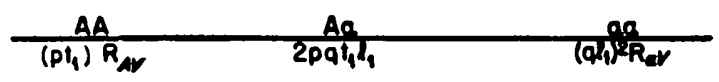

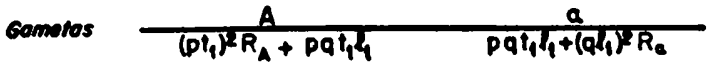

$$
\begin{aligned}
& =p t_{1}\left(p t_{1} R_{A}+q l_{1}\right)=q l_{1}\left(p t_{1}+q l_{1} R_{2}\right) \\
& =p t_{1} t_{2} \quad=q l_{2}
\end{aligned}
$$

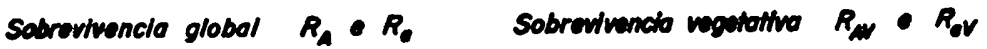


Se calcularmos com estas fórmulas séries de valores $t$ ou 1 notaremos que eles serăo inicialmente bem diferentes, tornando-se porem quase iguais quando atingirmas o equilibrio.

Com a ajuda destas fórmulas calculámas várias séries de curvas para diversas combinaçóes de valores de $\mathbf{R a}$ e $\mathbf{R a}$ (Fig. 1). Em cada um destes casos considerámas tres modalidades: 1) que toda a eliminaçăo fósse vegetativa; 2) que fasse apenas reprodutiva, ou 3) que fasse mista, com contribuiçăo igual de ambas as componentes. Lembraremos que definimas o valor da sobrevivencia global como o produto da sobrevivencia vegetativa e reprodutiva. Discutiremos em detalhe os exemplos, tabelados nos Quadras e ilustradas graficamente, mais adiante, pondo aqui apenas em destaque alguns pontos gerais.

Conclušo: Tódas as curvas demonstram claramente o seguinto: as mudanças são inicialmente relativamente acentuadas, aproximando-se depois, asintóticamente, a uma linha horizontal, indicando que o equilibrio está se aproximando.

3) Sobrevivéncias dos homozigotos menores que as dos heterozigotos.

Limitaremas a discussăo de cinco casos com a eliminaçáo de intensidade diferente, mas todos com a mesma proporção inicial dos gens $A$ e a, sendo então: $p$ igual a $q$ igual a 0,5. As curvas para outras proporçסes iniciais podem ser calculadas pelas fórmulas ou por interpolação gráfica.

Os cinco casos (Quadro 3 e gráftco Fig. 1) correspondem aos seguintes valores de sobrevivência global: 


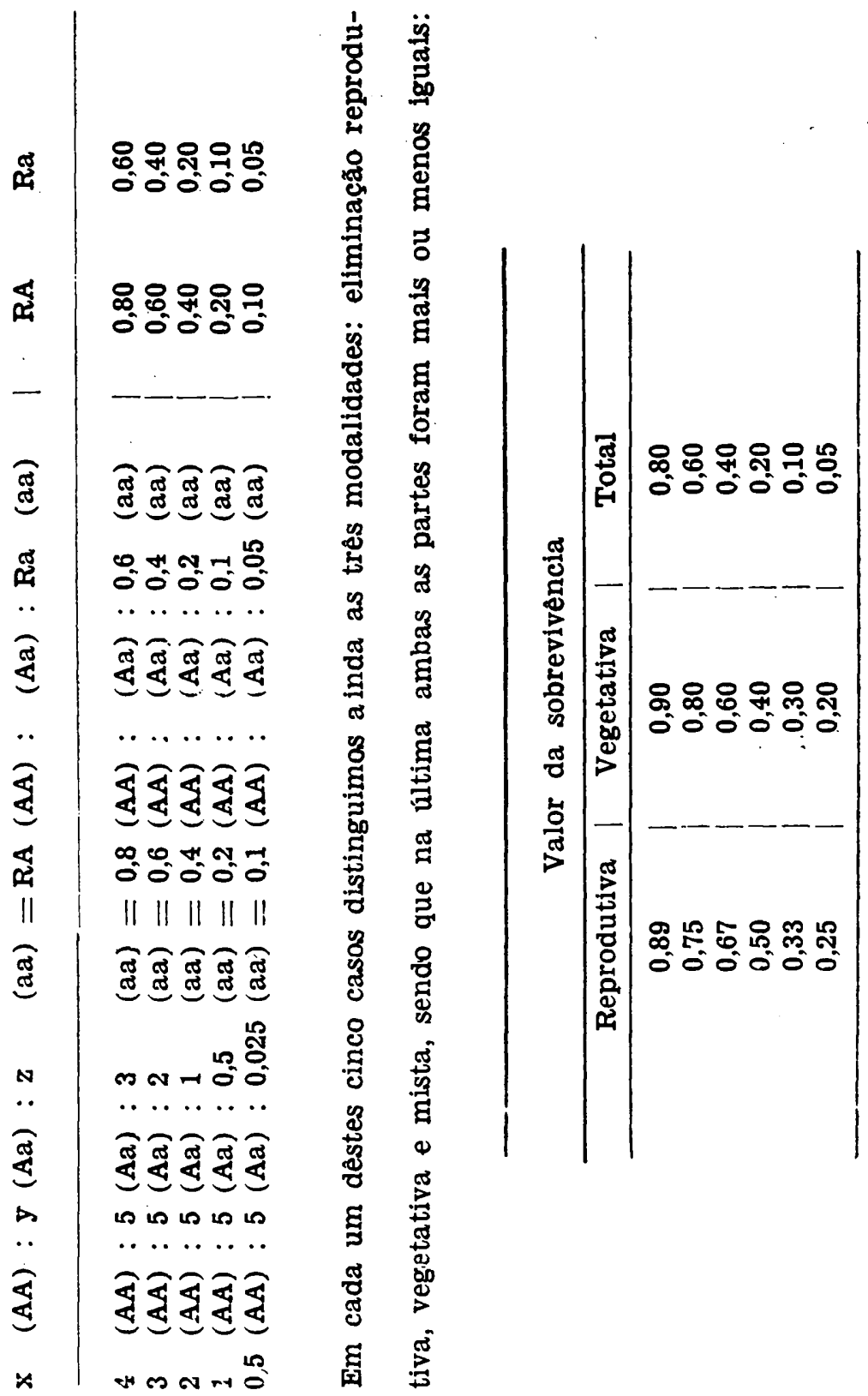


As frequências dos genótipos no equilibrio podem ser procuradas no Quadro 2.

Os gráficos da Fig. 1 mastram que a alteraçáo das frequências é no inicio muito rápida até que as curvas se aproximam as linhas horizontais quase retas, com a aproximaçáo para o equilibrio.

Se compararmas as atuais valores das frequencias podemas constatar o seguinte:

Os tres primeiros exemplos foram escolhidas de tal modo que os valores de RA săo sempre o dobro das valores de $\mathbf{R a}$ e deste modo os resultados são bem comparáveis. Podemos deduzir deles que, a aproximaçăo ao equilíbrio será tanto mais rápida quando menores forem os valores de sobrevivencia ou, com outras palavras, quanto mais forte for a eliminaçáo. No primeiro caso, com os valores de 0,1 e 0,05 para as sobrevivencias, precisamos apenas quatro geraçós; para os valoras de 0,2 e 0,1 sฐ̃o necessárias seis geraçסes; finalmente para os valores de 0,4 e 0,2 o número necessário ş̊o 10 geraçס̄es.

Nas casos restantes com valores de sobrevivencia de 0,6 e 0,4 , e de 0,8 e 0,6 respectivamente, mais do que 20 geraçóes serăo necessárias para atingir uma aproximaçăo até a segunda decimal das frequencias (em porcentagens) ou quatro decimais quando expressa em fraçós.

in interessante notar-se um fato de grande importancia blologica: nos casos em discussão as frequencias dos heterozigotas tornam-se maiores do que as dos homozigotos, e para poder interpretar meihor os resultados dos cálculos devemas esclarecer qual a situação genética correspondente.

H evidente que se trata de casos nos quais os heterozigotos mostram um aumento de vigor ou uma "Heterasis". Encontramos este fenomeno em muitas espécies de plantas e também em alguns animais acostumados a reproduçăo cruzada. O tipo mais extremo é representado pelo milho. Heterosis é também um fenomeno muito comum em cruzamentos interespecificas e a literatura está cheia de exemplos disso.

Trata-se em geral de segregaçōes polifatoriais, e uma heterose acentuada é devida a heterozigotia simultanea de um grande número de gens. De acórdo com a clássica teoria de East e Jones, o vigor dos híbridos, pelo menos em milho, nåo era atribuido a heterozigotia de certos gens, mas ao fato que gens dominantes para vigor, ligados estreitamente entre si genèticamente em fase de repulsăo, apenas podem-se reunir em híbridos heterozigotos para um número apreciável de fatores dominantes. Esta hipótese ficou de fato até hoje apenas uma "working hypothesis", sem comprovaçăo defini- 
tiva. A prova decisiva consistiria na obtençáo de uma linhagem dominante homozigótica que náo sofrerla as efeitos do "inbreeding", mas mantivesse permaizente o seu vigor. Pareceme um fato de grande importáncia que até hoje năo fol encontrada nenhuma linhagem desta natureza, e isto apesar do estudo de dezenas de milhares de autores nos ultimos trinta anos! Assim talvez deveríamos modificar a hipótese e atribuir o aumento do vigor a heterozigotia genica, e neste caso as nossas deduçoes matemáticas sobre o equilibrio em populaçరes com valores de sobrevivencla dos homozigotas menores daqueles dos heterozigotos ganha interesse geral. Assim as deauçoes que podemos tirar dos exemplos acima discutidos têm evidentemente uma importancia geral. Sem antecipar demais as pontos a serem discutidos nos capitulos finais deste trabalho, mencionarei já dois pontas importantes, com referencia à genética aplicada e outro à teoria da evoluçáo.

Desde cêrca de 10 anos estamas tentando desenvolver um novo método de melhoramento para o milho, o processo da obtençáo de "populaçóes heterozigotas balançadas", isto é, de populaçóes que se mantem automaticamente vigorosas e heterozigotas. Sabemas que em milho a viabilidade e fertilidade se diminuem com a autofecundaçáo e que como demonstraremos mais tarde a autofecundaçáo automàticamente aumenta a homozigasis. Se acentuarmos ainda a eliminação artificial no campo durante os trabalhos cultura:s e ainda na colheita, de todos os individuos mais fracos, podemos fàcilmente chegar à uma eliminação muito forte dos homozigotos. Se supomos que, por exemplo, um terço ou mais de todas as plantas germinadas fôsse eliminado, o que ainda não representa um desbaste exagerado, e que as plantas parcialmente homozigotas têm ainda uma reduçáo acentuada na sua fertilldade, chegamas a valores de sobrevivencia iguais ou menores do que 0,20. Nestes casos, como demonstram os Quadros 2 e 3, teremos $70 \%$ ou mais de plantas heterozigotas no equilibrio final. Observel que de fato nestas condiçбes de seleçáo "massal" e reprodução cruzada livre, as populaçбes do milho podem manter o seu vigor.

Assim a espectativa do aparecimento de $70 \%$ ou mais de plantas heterozigotas na fase do equilibrio e o resultado exparimental estão de acơdo e as nossas deduçరes matemáticas dăo a explicaçáo teórica a um fenomeno observado anteriormente no campo experimental. Voltaremos ao assunto mais tarde.

Passaremas agora a questóes sóbre o mecanismo da evolução. Uma das grandes dificuldades da teoria da mutaçáo é o 
fato de que quase tódas as mutaçōes, até hoje observadas; săo prejudiclais quando aparecem, de modo que devem desaparecer da populaçáo, como demonstraremos num das capitulos seguintes. Mas a situaçăo será bem diferente se, ao mesmo tempo, os individuas heterozigotos para o novo gen mutado fásse um pouco mais vigoroso ou tértil do que os homozigotos para o gen năo mutado. Neste caso, de maior sobrevivencia dos heterozigotos, o novo gen, apesar de prejudicial, náo desaparece da populaçăo, mas ao contrário aumentaria a sua frequencia até atingir uma frequencia correspondente aos valores do equilibrio.

?

Conclusão: - Em vista da frequência de casos onde hibridos mostram um aumento de vigor $e$ as vezes de fertilidade, tanto em cruzamentos intra como interespecificos (heterosis), sofrendo ao mesmo tempo formas homozigotas uma redução do seu vigor e da sua fertilidade (inbreeding), as conclusōes as quais chegamos neste capitulo têm grande importancia tanto com referência à questões de genética aplicada como à teoria de evolução.

4) Sobrevivência reduzida de um dos homozigotos :

Passaremos agora para o segundo caso que corresponde à segregạçăo de fatores recessivas letais ou semiletais, onde um dos homozigatos, AA tem a mesma sobrevivencia que os heterozigotos, e o outro, aa, uma sobrevivencia menor. Substituindo nas equaçōes do equilibrio o valor de 1 para RA, obtemas o seguinte :

\section{Cosos esperiols:}

$$
\begin{gathered}
R_{A}=1,0 \quad 0 \leq R_{0}<1 \\
\frac{P_{e}}{P_{0}+q_{0}}=\frac{1-R_{a}}{1-R_{a}}=1 \quad \frac{q_{0}}{P_{0}+q_{0}}=\frac{0}{1-R_{a}}=2000 \\
0<R_{A}<1 \quad R_{0}=80,0 \\
\frac{P_{0}}{P_{0}+q_{0}}=\frac{1}{2-R_{A}}, \frac{q_{0}}{P_{0}+q_{0}}=\frac{1-R_{A}}{2-R_{A}}
\end{gathered}
$$

Ccm outras palavras, quando a sobrevivencia de um dos homozigotos e dos heterozigotos é igual, e a do outro homo- 
zigoto é menor, o equilíbrio é atingido quando sobram na populaçáo apenas os homozigotos do primeiro tipo.

O numero de geraçóes necessário para atingir o equilibrio ou qualquer outro nivel pode ser calculado no caso especial, quando há eliminaçáo completa de um dos homozigotos:

$$
R_{1}=1: R_{0}=0
$$

$$
\begin{aligned}
t_{1} & =p R_{A}+q=1 \\
t & =p t_{1} R_{A}+q l_{1} \\
& =p+q p=p(p+q) \\
t_{3} & =p t_{1} t_{2} R_{A}+q l_{1} l_{2} \\
& =p \cdot p(1+q)+q \cdot p \cdot p \\
& =p(1+2 q) \\
t_{4} & =p t_{1} t_{2} t_{3} A^{+}+q l_{1} l_{2} t_{3} \\
& =p \cdot p(1+q) \cdot p^{2}(1+2 q)+q p \cdot p \cdot p^{2}(1+q) \\
& =p(1+q)(1+3 q)
\end{aligned}
$$

$$
\begin{aligned}
l_{1} & =p+q R_{a}=p \\
l_{2} & =p t_{1}+q l_{1} R_{a} \\
& =p \\
l_{3} & =p t_{1} l_{2}+q l_{1} l_{2} R_{a} \\
& =p \cdot p(1+q) \\
& =p(1+q) \\
l & =p t_{1} l_{2} t_{3}+q l_{1} l_{2} l_{3}= \\
& =p \cdot p(1+q) \cdot p^{2}(1+2 q) \\
& =p(1+q)(1+2 q)
\end{aligned}
$$

\section{toremos poro in gorogeb}

$$
\begin{aligned}
& \text { AA : } D^{2}\left(t_{1} t_{2} t_{3} \ldots t_{m-1}\right)^{2} \\
& \text { Aa : } 2 p q\left(t_{1} t_{2} t_{3} \ldots t_{m-1}\right)\left(t_{1} t_{2} t_{3} \ldots t_{m-1}\right) \\
& \text { a a : } q^{2}\left(l_{1} l_{2} f_{3} \ldots f_{m-1}\right)^{2} \cdot R_{a}=0
\end{aligned}
$$

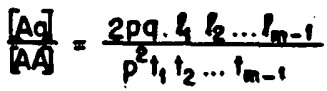

$$
\begin{aligned}
& =\frac{2 q \cdot p \cdot p \cdot p^{2}(1+q) \cdot p^{4}(1+q)(1+2 q) \ldots \quad r \quad(1+(m-3) q)}{p \cdot 1 \cdot p(1+q) \cdot p^{2}(1+2 q) \cdot p^{4}(1+q)(1+3 q) \ldots(1+(m-2) q)} \\
& =\frac{2 q}{1+(m-2) q} \\
& \frac{[A q]}{[A q]+[A A]}=[A q]=\frac{2 q}{2 q+1+(m-2) q}=\frac{2 q}{1+m q} \\
& \frac{[A A]}{[A A]+[A Q]}=[A A]=\frac{1+(m-2) q}{2 q+1+(m-2) q}=\frac{1+(m-2) q}{1+m q}
\end{aligned}
$$


Assim chegamos a uma fórmula bem simples que nos dá as relações entre as frequências iniciais da população e aquela na $\mathrm{m}^{\circ}$ geração, permitindo o cálculo ou das duas frequencias ou do número de gerações.

Para explicar a marcha da seleção, calculamos as cinco casos seguintes, com valores diferentes de sobrevivencia:

$$
\begin{aligned}
& x(A A): y(a a): z \quad(a a)=1(A A): 1(A a): R a(a a) \\
& 5(\mathrm{AA}): 5 \text { (Aa): } 0 \text { (aa) }=1 \text { (AA) : } 1 \text { (Aa) : } 0 \text { (aa) } \\
& 5(\mathrm{AA}): 5(\mathrm{Aa}): 1 \text { (aa) }=1 \text { (AA): } 1 \text { (Aa) : } 0,2 \text { (aa) } \\
& 5 \text { (AA) : } 5 \text { (Aa) : } 2,5 \text { (aa) }=1 \text { (AA) : } 1 \text { (Aa) : } 0,5 \text { (aa) } \\
& 5 \text { (AA) : } 5 \text { (Aa) : } 4 \text { (aa) }=1 \text { (AA) : } 1 \text { (Aa) : } 0,8 \text { (aa) }
\end{aligned}
$$

Os dadas e curvas correspondentes, com frequencia inicial de $p$ (A) igual a $q$ (a) igual 0,5 constam no Quadro 4, e no gráfico (Fig. 2). evidente que a aproximação ao equilibrio é muito mais lenta do que nos exemplos discutidos no caso anterior. Mesmo no caso mais extremo, da eliminaçáo completa dos homozigotos aa, temos depois de 10 geraçoes ainda cêrca de $16 \%$ de heterozigotos. Assim a frequéncia dos gens a decresceu apenas $50 \%$ até $16 \%$, ficando ainda muito longe do valor do equilíbrio, que é zero.

Conclusão : - Sempre quando a sobrevivência de um dos homozigotos é igual à dos heterozigotos e a sobrevivência do outro homozigoto é menor, o equilíbrio será atingido quando o gen, contra o qual a seleção é dirigida, for completamente eliminado.

o número de gerações para atingir o equilíbrio é muito grande e tanto maior quanto menor a intensidade da eliminação e pode ser contado apenas em dezenas, centenas ou até milhares de gerações.

Do ponto de vista biológico o caso que nós acabamos de discutir é em geral considerado como o mais comum e até típico, como mecanismo da evolução. Ele corresponde à seleçăo de gens ou mutantes, recessivos, que reduzem o vigor e a viabilidade, isto é, que são letais ou semi-letais. Estes casos davam a impressão de que a seleção natural, e a evolução em geral, são processos muito lentos.

Não há dúvida que uma grande parte de mutações, naturais ou provocadas, são recessivas e afetam, pelo menos no inicio, desfavoràvelmente a sobrevivênc:a, mas como expliquei no capítulo anterior sabe-se muito pouco sobre as diferenças 
de viabilidade e fertilidade entre o homozigoto dominante e as heterozigotos. bem passivel que vários gens considerados como simples gens recessivos, dáo de fato heterozigotos com viabilidade e fertilidade aumentada, mas de outro lado ná pode haver dúvida que muitos gens săo de fato sem qualquer efeito fenotípico quando heterozigotos, isto é, são real e completamente recessivos.

Na genética aplicada as conclusõas expostas acima, têm também uma grande importancia. Elas demonstram que uma seleçáo simples contra homozigotos recessivas em populaçăo de reproduçåo cruzada, é um processo extremamente ineficientt e lento, levando dezenas ou mais geraçóes até dar um resultado decisivo, prazo este demasiado para qualquer trabalho de melhoramento. outro :

5) Sobrevivência maior de um homozigoto e menor de

Passamas agora a discutir casas onde a sobrevivencia diminui na ordem : homozigotos AA - heterozigotos $\mathrm{Aa}$ - homozigotos aa.

A fórmula dada acima para o equilíbrio não pode ser empregada agora, pois aparecem valores de frequencia negativos, isto é, sem significado biológico. Mas é fácil de mastrar que devemas distinguir entre o equilíbrio biológico e matemático:

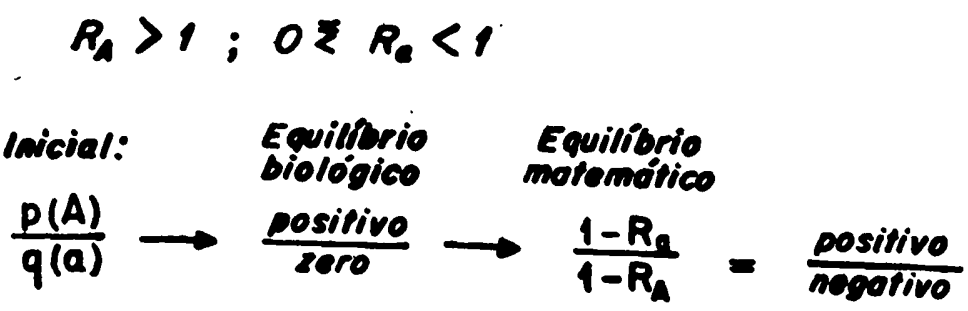

Assim o equilíbrio biológico será atingido quando os gens desapareceram da população.

Calculei a marcha da seleçáo para dois casos apenas, que constam no Quadro 5 e Fig. 3. 


$$
\begin{aligned}
& x(A A): y(A a): z(a a)=\operatorname{RA}(A A):(A a): R A(a a) \\
& 5(A A): 4(A a): 3(a a)=1,25(A A): 1(A a): 0,75(a a) \\
& 5(A A): 2(A a): 1(a a)=2,50(A A): 1(A a): 0,50(a a)
\end{aligned}
$$

Podemos tirar conclusz̃es dos dados do quadro 5 e Fig. 3, e formulas do modo seguinte:

Conclusões : - Quando um homozigoto (AA) tem maior sobrevivência e outro (aa) menor sobrevivência do que os heterozigotos 0 equllibrio final será atingido quando permanecerem na população apenas os homozigotos do tipo mais vível (AA).

eqste equilibrio final será atingido tanto mais ràpidamente quanto mais a sobrevivência dos homozigotos diferir entre si.

A importancia biológica dêste tipo de eliminaçáo é clara, pois trata-se do caso de gens letais ou semi-letais, chamados "dominantes", mas que na realidade são apenas parcialmente dominantes. um fato bem conhecido que êstes gens nåo somente săo relativamente raros, mas podem ser mantidos apenas quando compensamas a reduça da viabilidade e fertilldade das heterozigotos por uma seleçáo artificial bem dirigida em favor do gen semi-letal ou letal. Sem este cuidado especial, raças como o "Dexter" no gado, a raça "Dunker Pintado" no cachorro, a variedade "aurea em Bóca de Leão, etc., nåo podem ser mantidas.

6) Sobrevivencia superior de ambos os homozigotos :

Se ambos as homozigotos têm indices de sobrevivência diferentes e maiores do que um, encontramas de novo uma situaçăo na qual devemas distinguir entre equilíbrio biológico e o equilíbrio matemático.

$$
\begin{aligned}
& R_{1}>1 ; R_{a}>1 ; R_{1}>R_{a} \\
& \text { Equiliorio } \\
& \text { biológico } \\
& \frac{p(A)}{q(0)} \rightarrow \frac{\text { positivo }}{\text { zoro }} \\
& \rightarrow \frac{\text { posifivo }}{\text { negotivo }} \rightarrow \frac{\text { zero }}{\text { negotive }} \rightarrow \frac{1-R_{Q}}{1-R_{A}}=\frac{\text { merelive. }}{\text { negotivo }}
\end{aligned}
$$


Como no caso anterior, o equilíbrio biológico é atingido antes do equilíbrio teórico matemático, pois quando a frequência de um gen atinge o valor zero, termina o processo de seleçắo.

Porém sendo as frequências iniciais dos dois gens e a sobrevivência dos dois homozigotos iguais, a situação é diferente. Agora a frequência dos gens permanece inalterada, e as proporções dos genótipos zigóticos dependem apenas dos valores da sobrevivência vegetativa:

$$
\text { (AA) : (Aa) : (aa) = RAV: 1: RaV }
$$

Com valores da sobrevivência, $\mathrm{Rv}$, maiores que um, teremos a equação de um mecanismo de isolamento.

A importancia biológica desste modo de eliminação, apenas dirigida contra os heterozigotos, é muito restrita. Como único exemplo poderíamos citar cruzamentos interspecíficos entre variedades, bastante distanciadas entre si, onde a forma heterozigota torna-se desequilibrada, perdendo a viabilidade e fertilidade.

7) Eliminação diferencial nos dois sexos de um dos homozigotos :

Em todos as casos discutidos até agora supuzemos que a eliminação reprodutiva atingisse igualmente os dois sexos, mas conhecemos numerosos exemplos, onde a seleção no sexo feminino e masculino é bastante diferente. Então não podemos mais aplicar as fớrmulas, gerais, derivadas no início dêste capítulo, mas fórmulas, especiais. Estas podiam também ser derivadas, mas serão tão complicadas que não nos parece interessantes. Para mostrar em principlo que há pouca diferença entre os resultados de uma seleçăo reprodutiva igual nos dois sexos de um lado, e uma eliminaçáo diferencial nos sexos, de outro lado. Devemos empregar a média dos dois valores de seleção.

Assim temos na décima geração: 


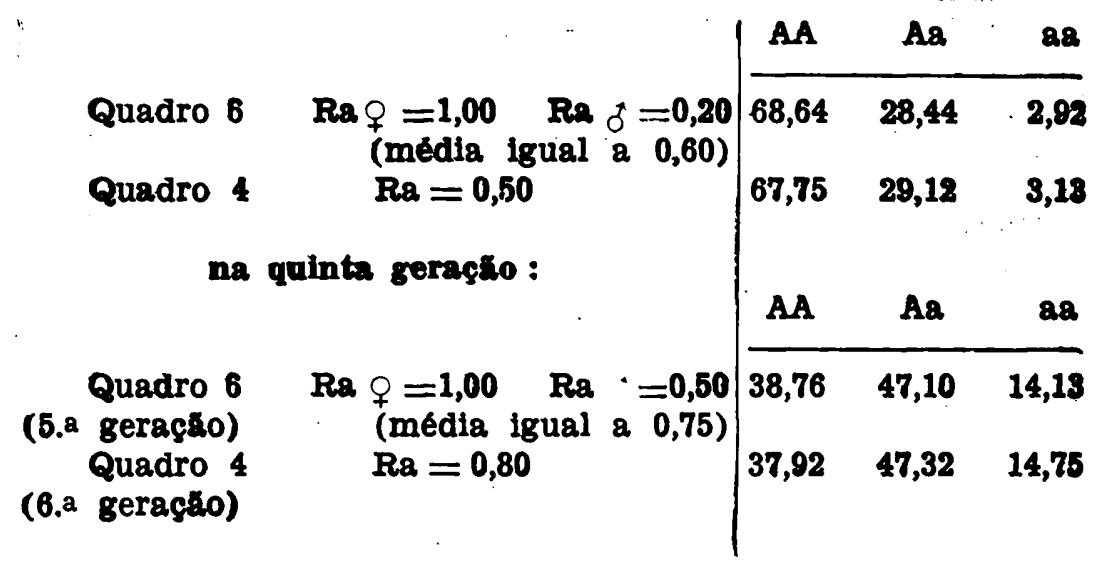

Conclusão: - Nos casos onde a eliminaçăo reprodutiva e diferente nos dois sezos, podemos tratar a situçăo essencialmente do mesmo modo como anteriormente, substituindo apenas os valores de sobrevivência em cada sezo por sua média e usar as formulas comuns para seleçixo em populaçð̌es cruzadas.

Casos de eliminaçăo e sobrevivencia diferencial nos dots sexos săo muito comuns, especialmente em plantas, e podemos achar multas referências na literatura. Limitar-me-el assim em mencionar alguns gens do milho:

Barren-stalk - Gen recessivo que determina o desaparecimento completo da espiga lateral, ou a substituiçăo por uma espiga estéril em nós encostados ao chăo, năo afetando a flecha. Do mesmo modo, do ponto de vista da eliminação, agem gens como sillk-less, branched ear, Tunicata, sendo apenas a seleçăo năo tăo completa no lado feminino como no caso anterior.

Numerosos gens para estirilidade masculina agem de modo opasto, reduzindo a fertilidade das flechas.

Devemos porém aqui fazer uma ressalva com respelto a Astes exemplos. Pelo exposto fica bem evidente que todos estes gens serăo eliminados das populaçōes, sendo o equilibrio final atingido com a sua eliminaçáo completa. Como podemas entao explicar que estes gens nåo sejam raros em milho, aparecendo, 
por exemplo, em nossos experimentos com milho sul-americano em Piracicaba, com frequencia relativamente grande?

Parece-nos que a antiga explicaçáo como simples gens recessivas está errada, e provavelmente trata-se de casos onde mesmo os homozigotos dominantes para esp gas e flechas normais sâo menas vigorosos do que as formas heterozigotas.

\section{8) Eliminação gonofásica :}

Mencionámas na introdução, a diferença entre eliminação zigofásica, seja vegetativa ou reprodutiva, e a eliminação gonofásica que existe apenas em plantas. Repetimas mais uma vez o ponto essencial desta distinção.

$\mathrm{Na}$ eliminação reprodutiva zigofásica teremas a seguint? situaçăo: uma eliminaçăo contra as heterozigotos, atinge igualmente tôdas as células sexuais produzidas por êles, seja da constitulçăo A ou a.

$\mathrm{Na}$ eliminaçăo gonofásica, a constituição das células go. nofásicas é decisiva, e uma seleção contra os gens da constitulção a năo reduz a fertilidade dos homozigotos aa e se dirige nos heterozigotos apenas contra o tipo a, sem atingir os gones da constituição A, dos heterozigotos e dos homozigotos AA.

Não nas parece necessário, para estes casos relativamente raras, calcular formulas matemáticas, e nos limitaremas por isso a dar alguns exemplos, distinguindo néles ainda duas passibilidades: eliminaçăo gametofítica em um sexo apenas, e eliminaçăo em ambos os sexas.

Os dados do quadro 7 e das gráficas nas Figs. 5 e 6, mostram que o equilíbrio será atingido quando os gens gametofíticos, responsáveis pela eliminaçáo forem eliminados da populaçăo. Esta eliminação é mais rápida quando se processa nos dois sexas e, quando os valores de sobrevivencia sáo baixos, a eliminaçáo gametofítica ou gonofásica é muito mais rápida do que a eliminaçáo zigofásica.

Gens de ação eliminativa na gonófase são encontrados no milho com relativa frequência, e também de um modo geral em plantas auto-estéreis, mas há uma profunda diferença entre êstes dois exemplos.

Nas plantas auto-estéreis não há pròpriamente uma eliminaçăo dirigida contra qualquer gen individual, mas apenas 
contra a formação de homozigotos, impedindo-se o funcionamento das tubos polínicos em todas os cruzamentos e naturalmente em autofecundaçăo, que podiam resultar na formaçăo de homozigotos. Assim năo se trata de um mecanismo geral de eliminaçáo, mas sim apenas de um processo muito especial para impedir a formaçăo destes homozigotos.

Os gens gametofiticos que aparecem numa seleçáo de determinados gens, sắo especialmente estudados no milho, onde provavelmente os processos eliminativos sáo exagerados no sexo masculino devido a necessidade dos tubos polínicas vencerem grandes distancias nas barbas longas. Conhecemos em milho, e tambem em Oenothera, uns poucas casas de gens ellminativas gonofásicas que agem em ambas os sexos, causando tanto uma concorrencia entre tubos polínicos como entre megaspórias.

Surge assim de novo um problema biológico: Se a eliminaçáo gonofásica chega ràpidamente à eliminaçăo da populaçáo dos gens desfavoráveis, como podemas explicar a sua relativa frequencia? tles deveriam ser, ao contrário, demasia. damente raras. Nåo temas desta vez nenhuma passibilidade de Justificar a hipótese que as heterozigotos para estes gens, de açăo ùnicamente gonofásica, sejam mais vigorosas do que os homozigotos. A explicaçăo reside provàvelmente num outro fato. Todos os autores que estudaram casos concretos de uma eliminação gonofásica, constataram que a sua intensidade sempre é bem variável, e que em geral é possivel separar grupas de individuos com eliminaçăo forte, média, fraca, multo fraca, etc.. Estas variaçరes podemos explicar, aceitando a hipótese que fatores modificadores afetem pronunciadamente a intensidade da eliminaçăo. Se eles conseguirem suprimir por completo a açăo fenotíplca dos gens de eliminaçăo, estes viltimos ficarăo conservados na populaçăo numa fase de inatividade. Em cruzamentos porém eles entram em combinaçăo com outras grupos de modificadores e assim podem recuperar a sua atividade. De fato, podemas observar e estudar a atuaçăo dos gens gametofiticos apenas em cruzamentos, observando anormalidades na segregaçăo mendeliana de gens ligados

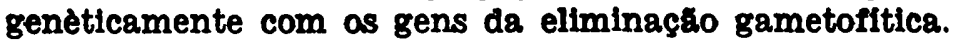

9) Resumo final sobre eliminação em populações de reproduçăo cruzada.

Os resultados principais aas quais chegámas nos capitulos anteriores podemos resumir agora da seguinte forma: 


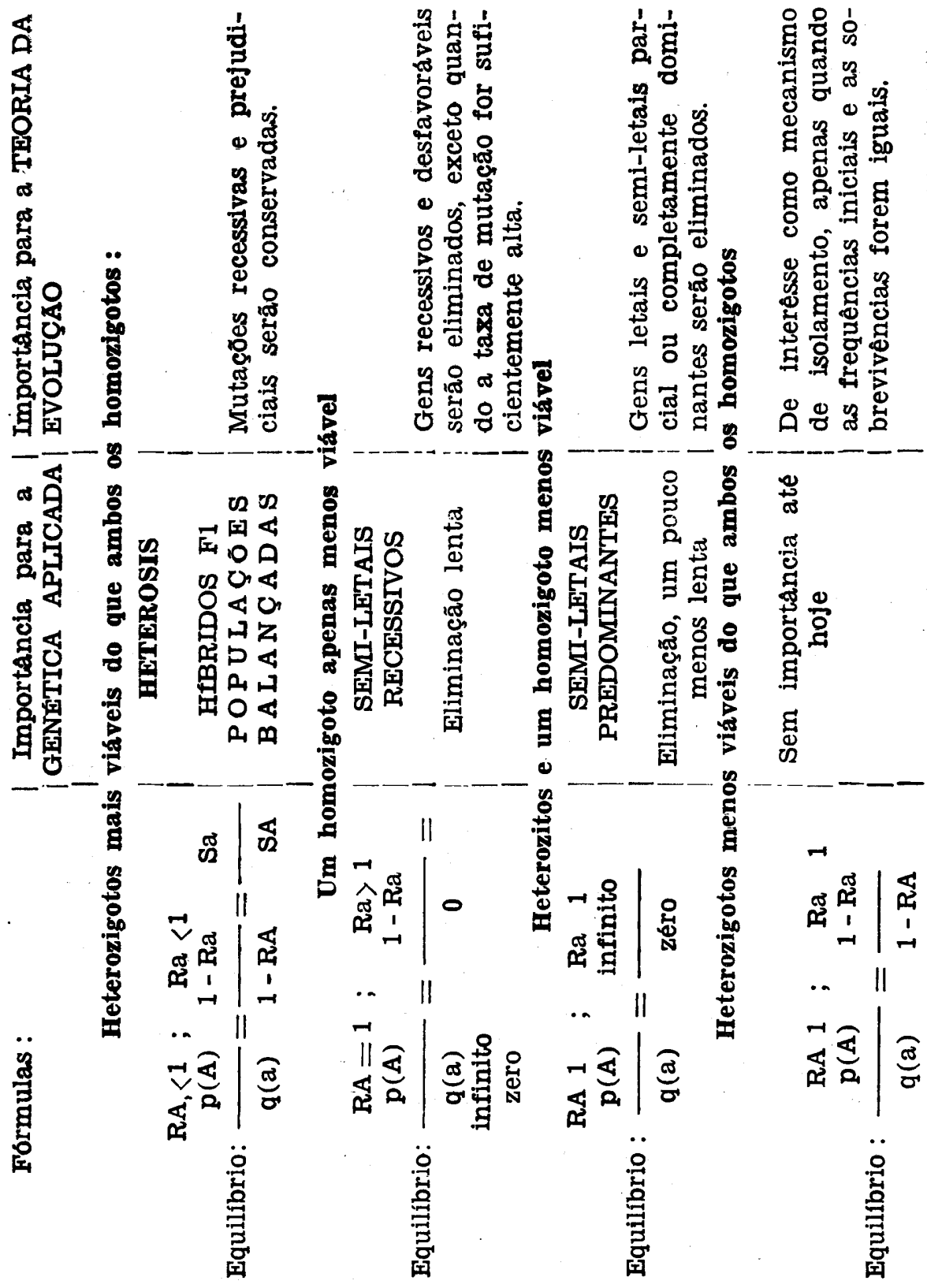


Quando a seleçăo é diferente nos dois sexos, podemas, mesmo assim, empregar as formulas dadas acima, usando como valor de sobrevivencia a média dos valores para as dois sexas.

Finalmente uma seleção gonofásica (fatores gametofiticas) tem de um modo geral os mesmas efeitas do que a ellminação zigofásica reprodutiva sòmente atingindo, com maior rapidez, o equllibrio da populaçăo com eliminaçáo completa.

\section{IV - POPULAÇOES COM AUTOFECUNDAÇAO E' SELEÇAO}

\section{1) Consideraçőes gerais :}

Adotámas as mesmas noçסes sobre eliminaçáo e sobrevivencia como no capítulo anterior sôbre as populaçoes de reproduçăo cruzada, expressando a sobrevivencia das homozigotos em relaçáo as heterozigotos.

\section{2) As formulas em geral :}

Supomas que partimos de uma populaçáo inicial onde as tres genótipas de uma segregaçăo monofatorial estăo representadas com as frequencias de $u(A A), v(A a)$ e $w(a a)$, supondo ainda que a sobrevivencia global tenha os valores RA e Ra. Podemas agora calcular as frequencias dos genótipos na população quando esta atinge o equilibrio, empregando o mesmo raciocinio que no capitulo anterior: as frequendias de uma geraçăo $n$ e da geraçăo seguinte $(n+1)$ devem ser iguals quando há equllibrio na populaçăo. 


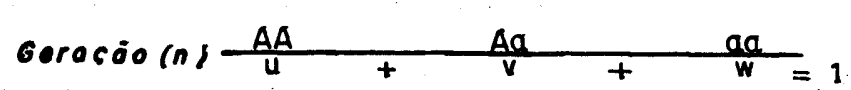

Gerogojo(av) $\frac{u R_{A}+\frac{v}{4}}{u R_{a}+v+w R_{a}}+\frac{\frac{v}{2}}{U R_{A}+v+w R_{a}}+\frac{w R_{a}+\frac{v}{4}}{w R_{A}+v+w R_{a}}=1$

Frequoncio(n) = Frequencial $n-1)$

( Heterozigotos:

$$
\begin{array}{r}
v=\frac{v}{2\left(U R_{A}+v+w R_{a}\right)} \\
u R_{A}+v+w R_{a}=0,5
\end{array}
$$

Homozígotos:

$$
\begin{array}{ll}
u=\frac{u R_{A}+\frac{y}{4}}{u R_{A}+v+w R_{a}}=\frac{u R_{A}+\frac{y}{4}}{0,5} & w=\frac{w R_{a}+\frac{v}{4}}{u R_{A}+v+w R_{a}}=\frac{w R_{a}+\frac{v}{4}}{0,5} \\
v=4 u\left(0,5-R_{A}\right) & v=4 w\left(0,5-R_{a}\right) \\
\frac{u}{v}=\frac{1}{4\left(0,5-R_{A}\right)} & \frac{w}{v}=\frac{1}{4\left(0,5-R_{a}\right)}
\end{array}
$$

$$
\begin{aligned}
& u: v: w=\frac{1}{4\left(0,5-R_{2}\right)}: 1: \frac{1}{4\left(0,5-R_{2}\right)} \\
& \text { Equilibria }\left\{\begin{array}{c}
=\left(0,5-R_{\alpha}\right): 4\left(0,5-R_{\Lambda}\right)\left(0,5-R_{d}\right):\left(0,5-R_{\mu}\right) \\
\frac{\sigma}{w}=\frac{0,5-R_{a}}{0,5-R_{\Lambda}}
\end{array}\right.
\end{aligned}
$$


Quando devemos tomar em consideraçáo na análise das proporçóes os efeitas de uma seleção vegetativa, devemos ainda acrescentar os valores da sobrevivência vegetativa, obtendo as proporçoes seguintes :

$$
\frac{[A A]}{[A a]}=\frac{\left(0,5-R_{a}\right) \cdot R_{A V}}{4 a,\left(0,5-R_{a}\right) \cdot\left(0,5-R_{A}\right)}
$$

A fórmula final para a proporção das homozigotas no equilibrio tem uma forma quase identica a fórmula das gametas nas populaçరes de reproduçáo cruzada, com uma diferença interessante: Onde no segundo caso apareceram as diferenças (1-R), encontraremas agora as diferenças (0,5-R). Dal podemas concluir o seguinte:

Quando ambos as valores de sobrevivencla tem valores menores do que 0,5 , as tres genótipas permanecem na populaçăo.

Quando um dos homozigotos tem uma sobrevivencia malor do que $\mathbf{0 , 5}$, o outro menor do que $\mathbf{0 , 5}$, so as primeiros se mantêm, à custa dos segundos homozigotos.

Quando finalmente ambos os valores de sobrevivencia forem maiores do que $\mathbf{0 , 5}$, ambos as genótipas permanecerăo presentes.

Podemos também calcular as frequencias das genótipos em cada geraçăo, derivada da populaçăo anterior por autofecundaçáo. Como se pode ver, pela deduçăo dada abaixo, é fácil chegar a uma fórmula geral para a enésima geração. 


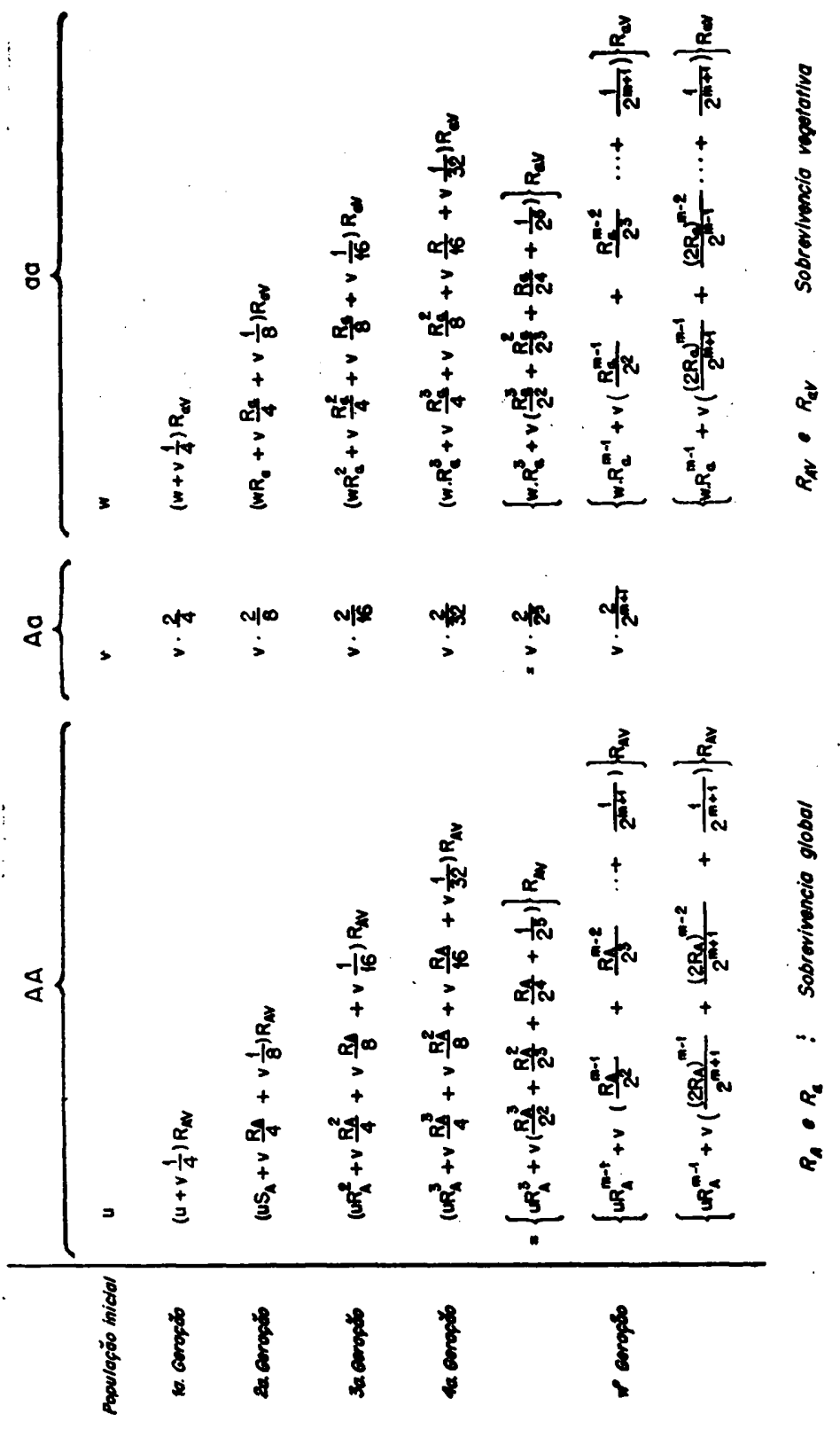


Na fórmula para as frequenctas dos homozigotos temos dois termos que devemos tomar em consideraça separadamente.

O primeiro termo atingirá os seguintes valores, para diferentes niveis de sobrevivencis $R$ :

$$
U \cdot R_{A}^{m-1}=4 u \frac{\left(2 R_{A}\right)^{m-1}}{2^{m+1}}
$$

Quondo $\quad R_{A}<0,5 \quad 2 R_{A}<1$

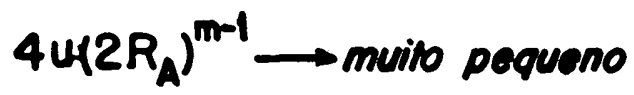

Quando $\quad R_{A}=0,5 \quad 2 R_{A}=1$

$4 u\left(2 R_{A}\right)^{m-1}=4 U$

Quando $R_{A}>0,5 \quad 2 R_{A}>1$

$4 u\left(2 R_{A}\right)^{m-1} \longrightarrow$ infinito

Assim podemas concluir que o termo desaparece por completo quando $R$ for menor do que 0,5 , quando a sua importancia depende nos casas de $R$ ser igual ou malor do que 0,5 das valores que atingirá 0 segundo termo das frequencias dos homozigotos.

O segundo termo das fórmulas contém em parentesis uma série exponencial com propriedades interessantes. Quando $R$ for igual a .0,5 cada membro da série fica sendo igual a um 
e o valor total da série torna-se igual a $\mathrm{m}$, que é o número de gerações. Sendo $R$ superior a 0,50 valor da série tende para 0 infinito.

Tomando agora os dois termos em consideraçáo em conjunto, teremos 0 seguinte resultado: Quando $\mathbf{R}$ for igual ou não muito diferente de 0,5 , o primeiro têrmo pode ser desprezado, pois $4 \mathrm{~m}$ será bem menor do que o produto m.v, mas quando $R$ se aproxima ao valor um, o primeiro têrmo ganha em pêso, não podendo mais ser desprezado.

\section{Cosos especiois :}

$$
R_{1}=1
$$

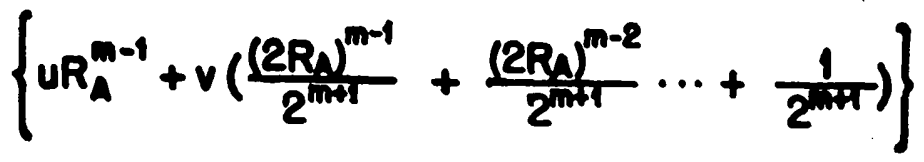

$=u+v \frac{2^{m-1}+2^{m-2} \cdots+1}{2^{m+1}}=u+v \frac{2^{m}-1}{2^{m-1}}$

$$
R_{1}=0,5
$$
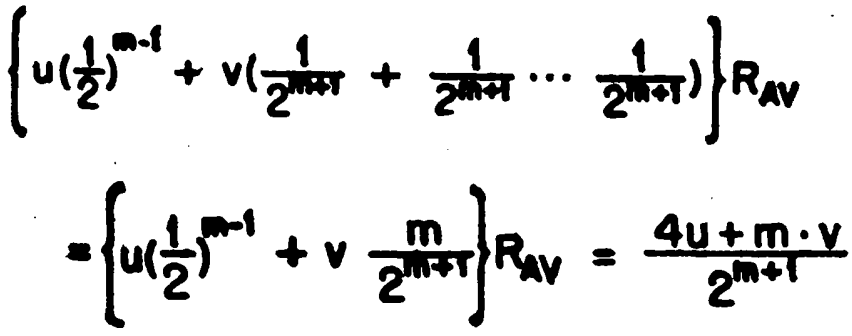
Finalmente quando $R$ for inferior a 0,5 o valor da série se aproximará a um valor finito, característico para cada valor de $R$, como se ve pela enumeraçăo que segue:

\begin{tabular}{c|c|c}
\hline $\mathbf{R}$ & $\mathbf{( 2 R )}$ & Valor final da série exponencial \\
\hline 0,50 & 1 & Infinito \\
0,45 & 0,9 & 10,00 \\
0,40 & 0,8 & 5,00 \\
0,35 & 0,7 & 3,33 \\
0,30 & 0,6 & 2,50 \\
0,25 & 0,5 & 2,00 \\
0,20 & 0,4 & 1,66 \\
0,15 & 0,3 & 1,4286 \\
0,10 & 0,2 & 1,25 \\
0,05 & 0,1 & 1,11 \\
0 & 0 & 1,00 \\
\hline
\end{tabular}

Tomando agora, em conjunto, as dois termas da fórmula para as homozigotos em consideração, podemas tirar as seguintes conclusóes: Para valores de $\mathbf{R}$ menores do que $\mathbf{0 , 5}$, o primeiro têrmo torna-se tão pequeno que pode ser desprezado, enquanto que o segundo térmo tende para um valor finito. Neste caso teremas para as três genótipos um iequilibrio, - que aliás já explicámos acima, e podemas dar a seguinte proporçáo tríplice para as frequências dos genótipas:

$$
1+(2 a)+(2 a)^{2}+(2 a)^{3} \ldots
$$

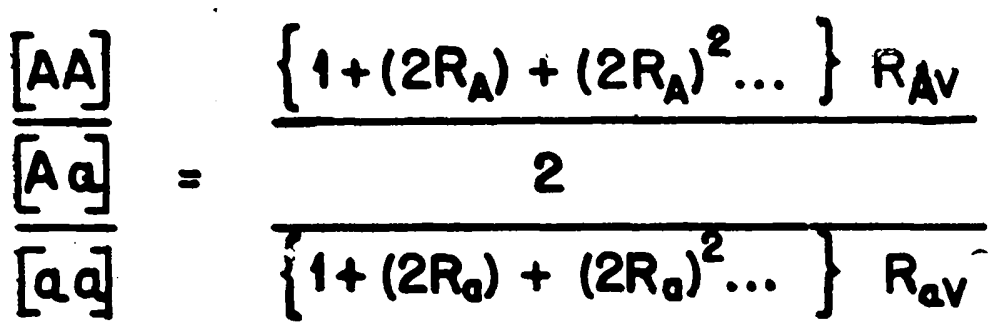


Constam do Quadro 8 as percentagens de algumas combinaçס̃es de valores de $R A$ e $R a$, todos menores do que 0,5.

Devido ao fato que a situaçăo biológica e matemática é muito mais simples no caso das populaçбes com autofecundação, podemos abreviar consideràvelmente a nossa discussão das casos especiais.

\section{3) Eliminação de ambos os homozigotos.}

O Quadro 8 e as curvas da Fig. 7 correspondem à quatro casos especiais com valores de sobrevivencia para ambos os homozigotos inferiores a 1.

Os dois casas com sobrevivências superiores a $\mathbf{0 , 5}$, isto é, $\mathrm{RA}=0,8 ; \mathrm{Ra}=0,6$ e $\mathrm{RA}=0,6 ; \mathrm{Ra}=0,4$ mastram claramente a tendencia das homozigotos com a sobrevivencia maior (AA) aumentarem as suas frequencias a custa das outras dois genótipos. Especialmente acentuada é a diminuiçáo da frequencia dos heterozigotos.

Nos outros dais casos há aproximação a um equilibrio para os tres genótipos, po:s agora os valores da sobrevivencia são inferiores a 0,5 . No caso $R a=0,4, R a=0,2$ esta aproximaçáo é muito lenta, mas no caso de $\mathrm{Ra}=0,2 ; \mathrm{Ra}=0,1$ a predominancia das heterozigotos na populaçáo final é muito zcentuada, especialmente quando a eliminação se dá tóda na fase vegetativa.

As curvas mostram formas muito interessantes. especialmente nos dols casas mencionados em primeiro lugar. A frequência das homozigotos menos viáveis aumenta no início e consideràvelmente, para depois diminuir.

Do ponto de vista biológico estes resultadas podem ser interpretados da forma seguinte: Mesmo quando os heterozigotas são mais viáveis do que ambas os homozigotos, aqueles dos homozigotos que forem relativamente mais viáveis e férteis do que as outros, seráo as únicas a permanecerem na populaçåo, exceto quando a sua viabllidade for bem fraca, e menor do que 0,5. Quando a sua sobrevivencia for multo fraca, isto é, menor do que $\mathbf{0 , 2 5}$, os heterozigotos começam a predominar nas populaçరes.

\section{4) Eliminação de um dos homozigotos.}

Quando um das homoz'gotos tem a mesma sobrevivência que os heterozigotas, e o outro uma sobrevivencia menor, o equilibrio final é atingido com o desaparecimento total dos outras homozigotos e dos heteroz'gotos. Os dados no Quadro 8 e as 
curvas dăo uma impressão da velocidade com a qual êste equilibrio é atingido; e podemas constatar que ele sempre é consideràvelmente superior do que fol achado para as populações com cruzamento livre.

Para chegar praticamente à eliminaçăo total das genótipos que contêm o gen a, precisamos de cêrca de 10 geraçōes quando a sobrevivencia dos homozigotos aa for igual ou inferior a 0,5. Quando ela for maior, por exemplo igual a 0,8, serão necessários cêrca de 25 geraçóes.

A importância biológica reside no fato que em populaçóes autofecundadas qualquer gen recessivo letal ou semi-letal fica ràpidamente eliminado, nåo restando nem homozigotas nem heterozigotos na populaçăo, mas apenas as homozigotos para o gen normal de viabilidade completa.

Quando o valor de sobrevivencia de um ou ambos as homozigotos for maior do que um, o valor da série exponencial nas formulas cresce muito depressa, de modo que serǽo atingidas logo valores altos. Com outras palavras, os heterozigotas somem depressa da populaçáo, e a velocidade com a qual as homozigotos menos viáveis desaparecem depende da proporçăo da sobrevivencia dos dois homozigotos.

A importáncia biologica destes fatos é a seguinte:

Gens semi-letais ou letais p:edominantes (com sobrevivenc'a de um homozigoto maior que 1 e do outro menor) desaparecem relativamente bem depressa da populaçăo, sobrando apenas os homozigotos do tipo bem viável.

Sem entrar numa discussão detalhada, podemas repetir o que fol já dito no capítulo IV, 5. Podemos usar as formulas comuns, empregando as médias dos valores da sobrevivencia nos dois sezos.

\section{5) Eliminação gonofásica.}

A eliminação gonofásica pođe tomar um aspecto especial em populaçóes autofecundadas, quando há uma eliminação nos heterozigotos. Isto acontece sempre em populaçőes de reproduçáo cruzada, pois aqui imaginamos que todos os gámetas formam uma mistura com a qual é efetuada a fertilizaçăo. Quando porém há autofecundaçăo, uma mistura de genótipos das gâmetas é encontrada apenas nos heterozigotas, de modo que o efeito da competiçăo se faz sentir apenas nêles. Assim uma competiçáo dos tubas polínicas ou de megaspórios, altera a proporção dos descendentes dos heterozigotos. $O$ resultado final será assim apenas a eliminação dos heterozigotos, e uma 
certa alteração na proporção dos homozigotos. Gens gametofíticos podem assim ser preservados em plantas autofecundadas.

9) Resumo final sobbre eliminação em populações reproduzidas por autofecundaçăo.

Heterozigotos mais viáveis do que ambos os homozigotos: HETEROSIS

$0,5<\mathrm{RA}<1 ; 0=\mathrm{Ra}<0,5 ;$ RARa

Equilíbrio: Sómente homozigotos AA | Eliminaçáo rápida

$0<\mathrm{RA}<0,5 ; 0<\mathrm{Ra}<0,5$

Equilíbrio: Presença dos três genotipas em proporção característica

para cada valor de $\mathbf{R A}$ e $\mathbf{R a}$ D.

Equilibrio entre as tres genótipas

Possibilidade de preservar populaçőes balançadas, sem perda de gens.

Heterozigotos e um homozigoto menos viável

\section{SEMI-LETAIS PREDOMINANTES}

$\mathrm{RA}>1 ; \mathrm{Ra}<1$

Equilíbrio: Sơmente homozigotos AA | Eliminação ráp:da

Heterozigotos menos viáveis do que ambos os homozigotos

$\mathbf{R A}>1$; $\mathbf{R a}>1$; $\mathbf{R A}>\mathbf{R a}$

Equilibrio: Sómente homozigotos AA | Eliminação rápida

Este resumo demonstra claramente que a principal importáncia da autofecundação obrigatória em populaçoes é que ela causa uma eliminação rápida em quase todas as casas consideradas dos heterozigotos e das homozigotas para gens que causam menor viabilidade ou fertilidade.

Do ponto de vista da evolução chegámos a conclusăo que plantas, reproduzidas por autofecundaçăo natural, devem não sòmente ser pràticamente livres de gens letais ou semiletais, exceto quando eles aparecem de novo por mutaçăo, fato este corroborado pelas observaçбes experimentais em espécies como fumo, feijão (gênero Phaseolus), ervilha comum, trigo, etc.. Igualmente evidente, e comprovado por observaçóes diretas, é que nestas espécies qualquer planta deve ser alta ou completamente homozigota. 
V - Fatores controladores da eliminação.

1) Considerações gerais :

Pelo que fol discutido nas capitulas anteriores ficou evidente que podemas classificar as principais fatores que controlam a marcha da eliminaçáo em três categorias :

a) Variaçăo das frequencias iniciais.

b) Variaçáo da sobrevivência ou da intensidade de ellminação.

c) Variação do modo de reproduçăo.

Năo tomamos em consideraçăo aqui as complicaçóes devidas a uma inconstancia das gens. Uma vez que a taxa normal de mutação é bastante balxa, ela terá um papel bastante secundário nos casos em discussáo nesta publicaçăo. Por exemplo, uma taxa de mutação de um por mil, será capaz de contrabalançar apenas uma eliminaçáo muito fraca, correspondente a um indice de sobrevivencia de pelo menos 0,999 , sendo que taxas alnda menores do que 1:1000 nåo săo raras na natureza.

2) Variação da frequência inicial dos gens ou genótipos:

Trataremos em primeiro lugar de populaçōes com reproduçáo cruzada, e reunimos nas gráficos da Fig. 8 uma série de curvas que correspondem tôdas á mesma taxa de sobrevivencia :

\begin{tabular}{l|crr}
\multicolumn{1}{c|}{ Sobrevivencia } & AA & aa \\
\hline Vegetativa & $\mathbf{0 , 8 0}$ & $\mathbf{0 , 6 0}$ \\
Reprodutiva & $\mathbf{0 , 7 5}$ & $\mathbf{0 , 6 7}$ \\
Global & $\mathbf{0 , 6 0}$ & $\mathbf{0 , 4 0}$
\end{tabular}

Assim, dos três fatores em consideraçăo neste capitulo, dois săo aceitos como constantes : o modo de reproduçáo e o indice de sobrevivencia.

Podemos tirar do Quadro 2 a informaçáo que o equilibrio final será estabelecido neste caso quando os três genótipas estáo presentes nas seguintes proporçбes :

\begin{tabular}{c|ccc} 
Eliminaçăo mista & $\mathrm{AA}$ & $\mathrm{Aa}$ & $\mathrm{aa}$ \\
$\mathrm{RA}=0,6 ; \mathrm{Ra}=0,4$ & $33,33 \%$ & $55,56 \%$ & $11,11 \%$
\end{tabular}

Consideramos diversas frequências iniciais das dois gens A e a, desde valores de $p(A)$ Igual a 0,$999 ; q(a)=0,001$ até a proporção Inversa de $p(A)=0,001 ; q(a)=0,999$. 
A forma das sete curvas para cada um dos dois homozigotos mastra que elas se aproximam ao nivel do equilibrio, quer crescendo ou decrescendo do seu valor inicial. As curvas dos heterozigotos mastram uma forma mais interessante. Quando a frequencia inicial do gen $A$, ao qual foi atribuida a maior sobrevivencia, for presente inicialmente com um valor superior a 0,5 , a frequencia dos heterozigotos aumenta lenta e constantemente até atingir o equilibrio. Mas quando a frequencia inicial do gen $A$ for inferior ao valor de 0,5, a frequencia aos heterozigotos cresce até ultrapassar o valor do equilíbrio, para depois, diminuindo, aproximar-se a ele.

A velocidade da aproximação ao equilíbrio é bastante diferente nos sete casos. Quando começamos com apenas 0,001 (A) : 0,999 (a) o espaço representado no gráfico por quinze gerações, nem de longe é suficiente, sendo necessárias algumas centenas de geraçóes. Para a série das curvas que seguem, com $p(A)$ Igual a 0,01 , a aproximação em 15 gerações não é muito bôa, porém cêrca de 25 a 30 seráo razoàvelmente suficientes. Para as demais cinco casos desde $\mathrm{p}(\mathrm{A})=0,10$, $q(a)=0,90$ até $p(A)=0,999, q(a)=0,001$ um número $d z$ apenas quinze geraçoes ou menos ainda será pràticamente suficiente para que a população atinja a sua estabilidade.

Quanto mais a proporção inicial dos gens se aproximar a uma proporção inversa a das valores de sobrevivencia, tanto mals rápida será a aproximaçáo ao equilibrio, e quando o valor inicial for igual a esta proporçáo, entăo existiria equillibrio desde 0 inicio, e em vez de curvas, obteriamos, no gráfico, linhas horizontais.

Podemos resumir estes resultados da forma seguinte:

Quanto mais perto for a proporção inicial dos gens ao valor recíproco da proporção das sobrevivências, tanto mais rápido se atingirá o equilíbrio. Com os valores médios de sobrevivencia escolhidos, obteremos o equilíbrio em cêrca de 15 gerações, ou menos, para frequencias iniciais do gen mais viável entre 0,99 e 0,10. Quando a frequencia inicial for cerca de 0,01, serăo necessárias algumas dezenas, e quando ela fôr de 0,001 , algumas centenas de geraçoes.

As curvas das frequencias dos homozigotas aumentam ou diminuemi, até atingirem o nivel do equilíbrio, mas as curvas dos heterozigotos aumentam o seu nivel até aquele do equilibrio apenas quando a frequencia do gen $A$, mais favorecido, for inicialmente maior do que 0,50 ; porém, quando a sua frequéncia inicial fôr menor do que $\mathbf{0 , 5 0}$, as frequências dos $\mathrm{h}:-$ terozigotos sobem primeiro além do nivel do equilíbrio, para depois baixar de novo. 
3) Variações da sobrevivência.

Escolhemos como exemplo um caso, onde a frequência dos dois gens era inicialmente igual e onde houve reprodução por cruzamento livre. Supomos ainda que a sobrevivência numa primeira fase era a mesma como escolhida no capitulo anterior: ( $R A=0,6, R a=0,4)$. Supomas ainda que houve uma mudança brusca numa fase intercalada, invertendo-se a proporçăo das sobrevivencias, de modo que agora 0 gen a é o mais favorecido e o gen A o menos vível e fértil. Aceitamos no exemplo para cada uma das tres fases um prazo de quinze geraçóes que é suficiente para at:ngir o equilibrio, de acórdo com o explicado no capitulo anterior.

As curvas da Fig. 9 săo suficientemente explícitas, da modo que năo precisam ser explicadas com muitas palavras. Ficou evidente que a proporção das genótipas se altera profundamente na fase intercalada, mas que apesar do disturbio causado pela alteração dos valores da sobrevivencia na fase intermediárla, o equilíbrio inicial se restabelece ràpidamente na última fase.

Devemos fazer referência aquí a um trabalho muito importante de Wright e Dobzhansky (1947) que demonstram curvas correspondentes a um caso experimentalmente estudado em Drosophila. Uma vez que o espaço de tempo para cada experimento nesse trabalho era de poucas geraçס̃es, náo se chegou com certeza ao equilibrio final.

\section{4) Variaçăo do modo de reprodução.}

Uma variação do modo de reprodução acontece muitas vezes em nossos experimentas, quando por exemplo, em milho, espécie normalmente cruzada, praticamos autofecundaçōes seguidas na fase experimental chamada de "inbreeding". Em animais muitas vezes aplicamos, em vez do cruzamento livre, acasalamentos entre parentes ou irmãos. Na natureza uma mudança na reproduçăo pode acontecer quando uma espécie atinge, com poucos individuos, um território novo, de modo que os poucos individuos ou se autofecundam de preferencia, por falta de outros individuas da mesma espécie, ou se acasalam de preferencia entre parentes, pela mesma razko da falta de individuos.

No exemplo escolhido, partimas de uma frequencia inicial dos gens igual a $p(A)=0,9, q(a)=0,1$, com os mesmos valores de sobrevivencia já usados nos dois exemplos anteriores, como valores médios. (Fig. 10) 
A alteração profunda devida à introdução da autofecundaçăo é bem notável, e se nós continuássemos a autofecundação nestas condiçóes por mais algum tempo, o gen menos viável desapareceria por completo e irremediàvelmente, da populaçáo. Estando o gen ainda presente, quando voltamas para o cruzamento livre, a populaçáo volta de novo para o seu equilíbrio anterior.

tostes resultadas já eram bastante conhecidos na genética aplicada, onde usamos justamente algumas autofecundações para eliminar gens indesejáveis em espécies de plantas, ou cruzamentas entre parentes em animais, que normalmente se reproduzem por cruzamento livre.

Nas questroes de evolução parece-nos ser interessante poder agora explicar muito bem o fato que uma especie que se distancia durante a sua filogenia do seu centro de origem, sofre uma diminuição sensível da sua riqueza em gens, paralela à d'stâncla do centro da origem.

\section{VI - ALGUMAS APLICAÇOES DOS PRINCIPIOS DA GE-} NETICA EM POPULAÇOES PARA A GENETICA APLICADA.

1) Consideraçôes sôbre os métodos da genética aplicada.

Nos capitulas anteriores distinguimos sempre dois tipos extremos: populações com reprodução cruzada e outras reproduzidas por autofecundação. Agora devemos discutir dois outros contrastes que às vezes são confundidos com os primeiros, mas que somente em certos casos coincidem com êles: Seleção massal e método pedigree.

$\mathrm{Na}$ seleçáo massal eliminamos numa população um número de individuos, sementes, etc., ficando com os outras escolhidas, para a continuaçăo. Os descendentes destes individuas são de novo misturados antes de se executar nova seleção e eliminação.

No método pedigree, de outro lado, controlamos não sòmente o processo de reproduçăo, mas mantemos separados os descendentes de cada cruzamento ou autofecundaçăo.

o primeiro método, que denominamos de seleçăo massal, é às vezes chamado um método "puramente empírico" como se fosse possivel hoje ainda fazer qualquer trabalho de real melhoramento "pelo empirismo puro", desprezando-se por completo todos as conhecimentos da ciencia moderna, da genética, da estatística ou da biologia em geral. Infelizmente podemas constatar, que há autores que preferem admitir alguma ignorancia 
neste sentido e que ainda justificam êste empirismo com argumentos aparentemente cientificos.

Existe apenas uma certa explicação desta atitude. As leis de Mendel e de Morgan, na sua forma mais simples e básica, não podem szr diretamente aplicadas aos problemas práticas, do mesmo modo que năo podemas calcular o trajeto de um toguete pela aplicaçăo das leis da gravidade ou da atraçáo das massas em vácuo. Para poder aplicar as leis naturais básicas de qualquer campo, seja físico, químico ou biológico, a casas concretas da ciencia aplicada, temas sempre que introduzir restriçōes, tomando em consideraçăo as numerasos fatores que ficam incontroláveis ou pelo menas inseparávels dos agentes principais, devemas tomar em consideraçāo na seleçăo justamente as leis e regras da genética em populaçōes.

Evidentemente devemos distinguir claramente entre dois problemas bem diferentes: qual o modo de reproduçăo mais preferivel: cruzamento livre ou autofecundação, e qual o modo de proceder mais vantajoso: manter os descendentes de todos os individuos juntos, isto é, o método massal, ou deixar bem separados os descendentes de todos os individuos, quer tenham sido autofecundados ou cruzados, isto é, método pedigree. A resposta depende naturalmente da finalldade visada em cada caso concreto.

Os aois problemas principais que temas de soluctonar nos trabalhas da genética aplicada săo: a) eliminaçáo de tipos indesejáveis e a obtenção de uma relativa pureza ou homozigotia, problemas que podemas resumir com a questão de homogeneizaçăo e b) a obtençăo de uma alta produtividade que exige, em muitos de seus casos, um alto grau de heterozigotla. Assim, em se tratando de tendencias realmente antogônicas e em direçőes opostas, é claro que cs métodos a seguir devem ser bastante diferentes.

2) Métodos de homogeneização..

Trataremos em primeiro lugar da HOMOGENEIZAÇAO, considerando primeiramente a simples eliminaçăo de gens recessivas. Assim năo haverá distinçăo entre as h̆ homozigotos dominantes e os heterozigotas. Na terminologia usada na parte anterior trata-se evidentemente de casas onde $R A=1, R a$ inferior a um. Demonstrámos que a eliminaçáo de gens sera muito lenta quando se tratar de reprodução cruzada, e muito rápida quando aplicar-se a autofecundaçăo. Como exemplo escolhemas um caso em que Ra é igual a zero, onde podemos determinar o número de geraçőes necessárias para que a frequencia do gen.a diminua do valor inficial para pm. 
114

Anais da E. S. A. "Luiz de Queiruz"

$$
R_{n}=1 \quad R_{a}=0
$$

Cruzamento Ilvre

$$
\begin{gathered}
{[A q]=2 q=\frac{2 q}{1+m q}} \\
m=\frac{1}{q m}-\frac{1}{q}
\end{gathered}
$$

Aufofocundogóo :

$$
\frac{(A A)}{(A a)}=\frac{u \cdot 2^{m+1}+v\left(2^{m}-1\right)}{2 v}
$$

$$
(A A)=v=1-2 q \quad(A a)=v=2 q \quad(a 0)=0
$$

$$
\begin{aligned}
& \frac{(A A)}{(A a)}=\frac{2^{m+1}-2 q \cdot 2^{m+1}+2 q \cdot 2^{m}-2 q}{4 q} \\
& -\frac{2^{m+1}(1-q)-2 q}{4 q}=\frac{2^{m}(1-q)-q}{2 q}
\end{aligned}
$$

$$
\begin{aligned}
\frac{(A 0)}{(A A)+(A 0)} & =\frac{2 q}{2^{m}(1-q 1)+q}=2 q_{m} \\
2^{m} & =\frac{q \cdot(1-q a)}{(1-q) \cdot q_{m}} \\
m & =\log \left(\frac{q \cdot\left(1-q_{m}\right.}{(1-q) \cdot q_{m}}\right): \log 2
\end{aligned}
$$


Com a ajuda destas fórmulas foram calculados as dados que constam no Quadro 11. A vantagem da seleçáo com autofecundaçáo é tăo evidente, que parece desnecessária qualquer discussăo. Devemos, porém, lembrar que éstes resultados podem ser abtidos, com certa probabilidade, apenas se nós trabaIharmas com populaçós bastante grandes, pols ao contrário. sêrias complicaços deverăo ser tomadas em consideraça. A variaçåo do acaso poderá afetar de modo tanto vantajoso como desvantajoso o processo da seleçăo. e este efeito da variagăo do acaso chegando ao seu extremo, fará cair a frequencia de um dos genótipas até zero. Atingido o gen que querfamos eliminar, o trabalho de seleçăo está terminado imediatamente, mas atingindo ao contrário, os homozlgotos que queremos conservar, a situaçăo se inverte e temas que iniciar de novo uma seleçăo, numa população compasta de heterozigotos.

Se aplicarmos além da autofecundação obrigatória, ainda o método "pedigree", o trabalho torna-se mais rápido, pois agora poderemos já nas primeiras geraçбes observar diretamente quais as linhagens que năo segregam mais, dando assim por terminado o nasso trabalho de seleçáo.

$\mathrm{Im}$ segundo lugar estudaremos casos nas quais náo estamas interessados em eliminar determinados genotipos ou gens, mas onde queremos atingir um alto grau de homozigotia. Supomas, para simplificar a discussáo que todos os genótipas, homozigotas ou heterozigotos fassem igualmente víveis e férteis. Sabemos, das fórmulas discutidas acima, que neste caso e com reprodução cruzada, permanecem na população todos as genótipos, tanto os homozigotos como as heterozigotos. Para atingir a homozigotia, pois o cruzamento livre náo é um processo apropriado, devemos recorrer a autofecundaçăo obrigatória, e surge entåo a pergunta: durante quantas geraçós devemas continuar com a autofecundaça ?

Sabemos que a frequencia de cada um das homozigotos AA como aa, será na mesma geraçáo igual a v. (2m - 1) : $2 m+1$, mais a frequencia inicial dos homozigotos, mas para simplificar a situaçăo suporemas que haveriam inicialmente apenas individuos heterozigotos. Neste caso a frequencia de qualquer homozigoto $\mathrm{AA}$ ou aa, será igual a $(2 \mathrm{~m}-1): 2 \mathrm{~m}$. Admitimos ainda que inicialmente os individuos sejam heterozigotos para $30,20,10$ e 5 pares de fatores.

Podemos agora facilmente calcular, para a mesma geração, a frequencla das individuos completamente homozigotos, ou heterozigotos para 1, 2, 3, etc., pares de fatores. Para isso é suficiente calcular os termos do binomio: 




O Quadro 12 dá as frequencias das individuas totalmente homozigotas numa população que era inicialmente heterozigota para 5,10,20 e 30 pares de fatores para a tercelra, quarta, quinta e sexta geraçăo de autofecundação. De acórdo com este quadro parece-nos necessário, para atingir homozigotia com bastante frequencia, continuar as autofecundaçōes pelo me nos durante seis geraçóes.

Em muitos casos, porém, náo será realmente necessário atingir um grau táo alto de homozigotia.

Calculámos, então, para a segunda, terceira e sexta geraçóes de autofecundação de populações heterozigotoas para 30, 20, 10 e 5 pares de fatores as têrmos sucessivos do binômio, dado acima, para conhecer as frequencias de genotipos, heterozigotos para nenhum, um, dois, etc., pares de fatores (Quadro 13).

Começamos a discussáo com a terceira geraçáo, e apllcamos o limite de $5 \%$ de significancia. Acumulamos as frequencias dos genótipas sucessivamente, heterozigotos para nenhum, um, dois, etc., pares de fatores, até que a sua soma atinja ou ultrapasse justamente a valor de 0,95. Assim podemas considerar como improvável de se achar na população da 3.a geração um individuo heterozigoto para mais pares de gens do que a última classe incorporada na frequência acumulada.

Podemos considerar como provável que 95\% dos individuos seræ̃o heterozigotos para nenhum até 7 pares de fatores nas descendencias de heterozigotos para 30 pares de gens. A heterozigotia atingiria entáo um máximo de um quarto dos fatores envolvidas: Aproximadamente a mesma proporçăo encontramos para as demais populaçőes individuais heterozigotas, para 5 ate 10 pares de gens. Em multas casas de melhoramento podemos considerar tal grau de homogeneizaçáo como satisfatorio, especialmente quando uma homozigotia excessiva cause uma perda demasiada de vigor.

-Quando queremos uma homozigotia quase absoluta, devemos continuar a autofecundaçáo até a sexta geraçá, pois então com uma probabilidade inferior a $1 \%$ (ou apenas uma vez em cem) um individuo será heterozigoto para um par de fatores; em qualquer das cinco tipas de populaçбes heterozigotas que tomamas em consideraçá. ।

A aplicaçáo de apenas duas autafecundaçóes dá, porém, um resultado muito pouco satisfatório, e nåo parece muito 
compensadora. Neste caso cêrca de $9 \%$ incluem, todos genóthos desde homozigotos ate heterozigotas para mais do que um sétimo e um oitavo dos pares de fatores mendelianos, e os tipas mals homozigotos por sua vez săo bastante raras.

as dadas do Quadro 13 mostram que o aumento da eficácia da autofecundaçáo da segunda para a tercelra geraçăo é aproximadamente 0 mesmo que da terceira para a sexta geraçæo.

Temas agora aindạ de ressolver qual o processo que será preferivel: o massal ou o pedigree. Evidentemente daremos preferencia ao último.

Uma populaçăo conjunta de todas as individuos năo permite tirar qualquer concluš̆o sobbre o grau de homozigotia atingido, e a seleção dos indivíduos dentro da população para a continuaçăo do trabalho de autofecundaçăo é bastante difícil, por falta de um critério seguro. Dentro de uma populaçăo, composta do conjunto dos descendentes dos individuas autofecundados, as individuos mais fortes podem ser os mais heterozigotos ou ao contrário, homozigotos com maior resistencia contra o "inbreeding", quando os individuos mais tracos poderăo ser aqueles que, com pouca homozigotia, jâ sucumbem ao "inbreeding".

A comparação entre as individuos irmáas das linhagens pedigree nas permite distinguir entre as linhagens que ainda tem uma segregaçăo mais forte e outras mais homozigotas. Além disso, podiemos distinguir as linhagens que mals suportam as autofecundaçóes daquelas que ràpidamente se enfraquecem.

Um outro ponto importante representa a queståo: quantas linhagens pedigree devem ser encaminhadas e continuadas, e quantos indivíduos por geraçăo deverlam ser estudados? A resposta será naturalmente quanto mais, tanto melhor, mas na prática isso torna-se dificil pelas limitaçoes de espaço, da máo de obra e da assistencia técnica. A questăo da subdivisáo das linhagens iniciais pode ser decidida com mais segurança. Mostrámas que as individuas da terceira geraçăo serăo proviavelmente homozigotos para três, quatro ou mais pares de fatores, e assim teré pouca vantagem uma subdivisăo de linhagens, a partir desta geraçăo.

O numero de individuos nas primeiras geraçós deve ser razo\&velmente grande, para permitir uma boa avaliaça quantitativa do tipo e da Intensidade da segregaçáo. Podemos aceltar um número de cerca de 25 individuos mals ou menas como vantajoso. A partr da terceira geraçáo o número pode ser 
bastante reduzido, para 10 individuos ou até para menos ainda, pois agora a seleção năo seria muito rigorosa; devido ao alto grau de "inbreeding" já alcançado, e da reduçáo do vigor por ela causada.

No caso especial de plantas normalmente reproduzidas por autofecundação, pode ser às vezes interessante recorrermos ao processo massal. Por exemplo, depols de um cruzamento em trigo, fumo ou feijão, escolhemos apenas em cada geração até a sexta um número grande de indivíduos para a colheita de sementes, semeando-as misturadas. Atingiremos assim um alto grau de homozigotia sem obtermos uma população homogénea, pois ela permanecerá composta de um número grande de homozigotos de constituição genética diferente. Para obter homogeneidade, devemos instalar finalmente o método pedigree, e agora isolar as melhores linhagens.

Em conclusão podemos afirmar que tanto para a eliminação de genótipos indesejáveis ou para a obtenção de um alto grau de homozigotia, uma reprodução cruzada é um método completamente inutil, e devemos sempre recorrer a autofecundação, ou quando isto não lôr possível ,como em plantas dióicas ou em animais, devemos aplicar cruzamentos com a maior consanguinidade possível.

Indicamos, sempre que possível, o emprêgo do método pedigree e mesmo quando preferimos em casas especiais, proceder com a autofecundação em populações, devemos no final, recorrer à separação de linhagens, se quisermos alcançar uma homogeneidade completa.

3) Obtenção da maior Heterosis.

O problema da heterosis representa na genética aplicada uma das questões mais importantes, pois em numerosas espécies tanto de animais e muito especialmente de plantas, o vigor parece ser ligado a um alto grau de heterozigotia.

o método geralmente recomendado hoje é aplicado ao processo designado por East e Jones (1918), pelos têrmös "inbreeding and outbreeding". Ste processo foi especialmente desenvolvido para o milho, mas pode ser aplicado em muitas outras espécies. Consiste essencialmente no seguinte: primeiramente, na fase denominada "inbreeding" procura-se obter um alto grau de homogeneidade e homozigotia por autofecundaçరes continuadas em linhas pedigree. Depois serão cruzadas duas ou mais linhagens razoàvelmente puras, escolhidas pelo seu alto 
valor de "poder combinativo", isto é, aquelas que darão híbridos muito vigorasos e produtivos.

\section{4) Obtençüo da Heterozigosis (Heterosis).}

Expliquei nos capitulos anteriores, que-a homozigosis é indispensável para a obtenção inicial de homogeneidade, mas ela trás de outro lado consigo um grande inconveniente: a perda de vigor. Todavia, o único processo viável de se obter homogeneidade é a autofecundação, a qual por sua vez acarreta a homozigosis e a porda de vigor. Assim era necessário inventar um processo oposto que, sem perda da homogeneidade, introduzisse de novo um alto grau de heterozigotia. Fol o grande mérito de Shull e de East terem idealizado, para um caso especial e extremo, o melhoramento em milho, o método mais indicado, que é o método de "inbreeding e outbreeding" East e Jones (1918).

A parte técnica do processo pode ser resumida da forma seguinte:obtido, pelos processos de autofecundação em linhas pedigree durante pelo menos seis gerações um grau muito alto de homogeneidade e homozigosis, escolhem-se as linhagens que dão o maiọr aumento de vigor possível nos híbridos. Devido a alta homozigotia das linhagens, pràticamente tôdas as plantas do F1 terăo constituição quase idêntica, de modo que o conjunto dos individuos F1 representa uma população tão homogênea como as linhagens pais. Tanto por razoes práticas, mormente a dificuldade de se obter um volume bastante grande de sementes hibridas do cruzamento de duas linhagens relativamente fracas, como por razbes de natureza genética, a extrema homogeneidade dos hibridos da primeira geração, emprega-se frequentẹemente o cruzamento repetido de tres ou quatro linhagens autofecundadas.

Do ponto de vista teórico, êste método é perfeitamente lógico e está de acôrdo com as normas da genética; êle năo é - único que permite alcançar ao mesmo tempo heterozigotia e homogeneidade. Das regras dadas nos capítulos anteriores, podemos derivar outro método que dá, com uma aproximação às vezes suficiente, o mesmo resultado, método êste que denominei o processo das populações balançadas, e ao qual já fiz referências num capitulo anterior.

Mostrámos que tanto em populaçżes com reprodução cruzada e com valores de sobrevivencia das homozigotos inferiores a um, como também em populaçoes reproduzidas por autofecundação com valores de sobrevivência para os homo- 
zigotas menores do que 0,5, existe uma tendencia para os heterozigotos se tornarem cada vez mais preponderantes na populaçá, sem que qualquer um dos homozigotos desapareça. Limitando-nos às populaçóes com cruzamento livre, vemas no Quadro 2 que obteremos mais do que $50 \%$ de heterozigotos quando os valores de $\boldsymbol{R}$ forem iguais ou menores do que 0,6 , mais do que $60 \%$ de heterozigotos quando os valores de sobrevivencia forem menores do que 0,4 , e mais do que $70 \%$ quando a sobrevivencia for menor do que 0,2 para ambos os homozigotos.

A questão surge, então se será possivel aproveitar estas relaçóes e obter material onde a sobrevivencia, isto é, o vigor vegetátivo a fertilidade dos híbridos heterozigotos sejam maiores do que a sobrevivencia das homozigotas. Na realidade, tal situação é fácll de ser obtida em milho, por exemplo. Existem muitas tipos de milho, especialmente de milho indigena que nunca foram submetidos a qualquer processo intensivo de "inbreeding" onde o pequeno grau de homozigotia atingido na segunda autofecundaçăo pràticamente reduz - vigor ate perto de zero. Podemas, todavia, reduzir ainda artificlalmente a sobrevivencia, pela eliminaçáo total dos individuos mais fracas, semeando-se, por exemplo, várias grăos juntos na mesma cova e eliminando no desbaste as plantas fracas.

Assim existe a passibilldade teórica de obtermas populaçóes balançadas, que mantêm, pela combinaçăo do cruzamento livre e da sobrevivencia reduzida dos homozigotos, a sua composiçáo genética, com uma predominancia das heterozigotos. Estas populaçōes săo, evidentemente, um pouco inferiores do que os hibridos simples ou mesmo duplos e triplos, pois nem todas as indivíduos atingiráo o grau máximo de heterozigotia; também a heterogeneidade será mais acentuada do que nos híbridas" multiplas. Mas estas desvantagens podem ser, na prática, consideradas como amplamente compensadas pela passibilidade, em muitos casos, da manutenção automática destas populaçõ $\varepsilon$.

Populaçōes balançadas existem no milho, como já menclonámos, na maioria das variedades de milho indígena sulamericano, como também em algumas variedades comerciais produzidas em Piracicaba.

Darei, em outra publicaçáo, dedicada especialmente ao melhoramiento do milho, informaçóes mais destacađas, mas quero frisar que este método náo se aplica sỏmente a este cereal, mas de um modo geral é sempre aplicável em espécies de reproduçáo cruzada onde podemas escolher gens reduzindo o vigor e a fertilidade dos homozigotos. 
As populações com autofecundaça obrigatórta, se mantem num equilibrio final quando os valores de sobrevivencia forem menores que 0,5 para ambos as homozigotos. Quando estes valores $R$ săo menores do que 0,20 , com eliminação mista ou vegetativa, os heterozigotos tornam-se o t:po mals frequente do conjunto. Assim seria passivel, mesmo em plantas reproduzidas preferencialmente por autofecundaçåo, estrnbelecer populações balançadas essencialmente heterozigotas.

Fm resumo, podemos dizer o seguinte:

Para obter heterozigosis e homogeneidade simultaneamente, teremos sempre que aplicar um processo que nas proporcione um alto grau de homozigotia e homogeneidade, isto é, autofecundaçáo em pedigree.

Para restabelecer a heterozigotia, precisa alterar a marcha, e passar para o cruzamento, podendo seguir dois caminhos:

a) O método das hibridos implica simplesmente em um cruzamento, sem qualquer tentativa ou mesmo possibilidade teorica de se obter uma população estável. Teremos que manter as linhagens pedigree homozigotas e repetir continuadamente as cruzamentas controladas. Obtemos deste modo, em cada vez, nova heterozigotia e homogeneidade máxima, usando hibridas simples, e heterozigotia muito grande, combinada com menor homogeneidade no caso de hibridos múltiplos; b) O processo das populaçбes balançadas pode apenas ser aplicado quando há gens que, quando homozigotos, dão uma reduçáo do vigor e da fertillidade. Combinando tals linhagens e deixando-as em conjunto reproduzindo-se livremente por cruzamento, obteremos, em acordo com as princípios da genética em populaçбes, dentro de poucas geraçбes, uma populaçao estável, na qual predominam as heterozigotas.

interessante notarmas que mesmo em populaçóes reproduzidas por autofecundaçăo, é passivel obter-se populaçб̃es balançadas com uma alta frequencia de heterozigotos, desde que os indices de sobrevivencia das homozigotos sejam muito pequenos.

\section{VII - Algumas aplicaçбes à teoria da evolução.}

Nas discussóes sobre algumas aplicaçбes da teoria da genética em populaçóes à problemas do melhoramento, tomámos como ponto de partida populaçסes altamente heterozigotas e heterogeneas. Quando queremas porém estudar problemas da evolução e a sua relaçăo à questrós da gepética em populaçбes, devemas tratar de uma situaçáo inversa. O principal 
problema agora e a permanencia de novas caracteres hereditários que surgem na populaçáo, tendo uma frequencia ini. cial extremamente pequena. As observaçoes, extremamente numerasas, sobre mutaçoes naturais ou artificiais, sobre mutaçoes genticas ou aberraçóes citológicas, demonstraram que elas tem, quase sempre, uma sobrevivencia menor que as tipos originais.

Se nestes casas a sobrevivencia das heterozigotas for igual ou ainda menor que a dos homozigotos originais, năo pode haver a menor dúvida que a eliminaçáo dos novos gens das populaçóes será inevitável e isto tanto com reproduçăo cruzada como com autofecundaçáo. Já mencionámas este problema em alguns dos capitulas anteriores, na discussão dos diversos casas de combinaçóes de valores de sobrevivência, e mencionámos nesta ocasiáo que a taxa de mutaçáo ou de aberraçáo citológica é em geral tro baixa que dificilmente poderá compensar o efeito da baixa sobrevivencia. A eliminaçăo pode se tornar muito lenta, mas o número de individuos, carregando o novo carácter hereditário permanecerí sempre pequeno, até desaparecer por completo. Esta situaçăo é evidentemente pouco satisfatoria para explicar como podem ser acumulados novos carácteres hereditários no curso da evoluçăo.

A situaçăo porém muda, se pudermos supor que, apesar da reduçáo da sobrevivéncia dos novos homozigotas, houve um aumento da sobrevivencia dos heterozigotos além do nivel da sobrevivencia dos homozigotos originais.

Trataremos em primeiro lugar da situaçăo em populaçбes reproduzidas por cruzamento livre. Como foi demonstrado acima o equilíbrio final dos gens na população é independente das frequencias iniciais e depende da proporçáo.

$$
\frac{p(A)}{q(a)}=\frac{1-\mathbf{R a}}{1-\mathbf{R A}}
$$

Suporemos, como caso extremo, que a sobrevivencia dos homozigotas originais AA seja apenas ligeiramente inferior a dos novos heterozigotos, por exemplo igual a $0,90,0,95$ ou 0,99 e que as novas homozigotos sejam completamente inviáveis. Assim obteremas a seguinte frequencia dos gens $A$ e a e das genótipos AA e Aa no equilíbrio final : 


$$
\begin{aligned}
& \frac{p(A)}{q(a)}=\frac{1}{1-0,99}=100: 1 \begin{array}{l}
\mathrm{AA}=98,03 \% \\
\mathrm{Aa}=1,96 \%
\end{array} \\
& \frac{p(A)}{q(a)}=\frac{1}{1-0,95}=20: 1 \begin{array}{r}
A A \\
A a=90,91 \%
\end{array} \\
& \frac{p(A)}{q(a)}=\frac{1}{1-0,90}=10: 1 \begin{array}{r}
A A=83,50 \% \\
A a=16,66 \%
\end{array}
\end{aligned}
$$

* muito interessante notarmos que nestes tres casas ficaremos finalmente com 2 até cerca dé $17 \%$ de indivíduos heterozigotos para a nova mutaçø̃o, e isto independente da taxa de mutação ser 1 em mil ou 1 em um milhão. Experimentalmente será muito dificil provar diferenças tăo pequenas da sobrevivencia, representadas por valores entre 0,90 e 0,99 .

Num segundo exemplo aceltaremas a passibilidade de que - novo gen mutado apenas reduza um pouco a viabilidade do recessivo, ou seja ate $\mathbf{R a}$ igual a 0,80 . Neste caso obtemos as seguintes frequencias genicas e genotipicas:

\begin{tabular}{l|c|r|r|r|r}
\hline $\begin{array}{c}\text { Homozigoto } \\
\text { original }\end{array}$ & $\begin{array}{c}\text { Homozigoto } \\
\text { novo }\end{array}$ & A:a & AA & Aa & $\mid$ \\
\hline $\mathbf{R}=\mathbf{0 , 9 9}$ & $\mathbf{R}=\mathbf{0 , 9 0}$ & $20: 1$ & $\mathbf{9 0 , 7 5 \%}$ & $\mathbf{9 , 0 7 \%}$ & $\mathbf{0 , 2 5 \%}$ \\
$\mathbf{R}=\mathbf{0 , 9 5}$ & $\mathbf{R}=\mathbf{0 , 8 0}$ & $\mathbf{4}: 1$ & $\mathbf{6 4 , 0 0 \%}$ & $\mathbf{3 2 , 0 0 \%}$ & $\mathbf{4 , 0 0 \%}$ \\
$\mathbf{R}=\mathbf{0 , 9 0}$ & $\mathbf{R}=\mathbf{0 , 8 0}$ & $\mathbf{2}: 1$ & $\mathbf{4 4 , 4 4 \%}$ & $\mathbf{4 4 , 4 4 \%}$ & $\mathbf{1 1 , 1 1 \%}$ \\
\hline
\end{tabular}

O resultado do equilibrio final deste exemplo é talvez ainda mais surpreendente do que no exemplo anterior. Agora, a frequencia do novo gen aumenta de tal modo até atingir, independente da sua frequencia inicial, sempre muito pequena, uma fraçăo de um vigésimo até um terço dos gens da populaçăo!

A questăo do tempo necessário para atingir êste equillbrio também pode ser respondida num sentido multo favoravel para a teoria de evoluçấo. Mostramos que para uma sobrevivencla média serăo aproximadamente suficientes $10 \mathrm{ge}-$ raçరes, entre $\checkmark$ inicio e o equilibrio, sempre quando o gen mais viável também tem a sobrevivência maior do que o seu alele. 
Assim chegamos à conclusão que, para a evoluçăo, é muito favorável um sistema no qual os heterozigotos para um novo gen mutado sejam no min mo ligeiramente mais viáveis do que as homozigotos originais, e no qual os homozigotos originais por sua vez sejam mais viáveis do que os homozigotas novas. Nestas condiçzes o novo gen tende a aumentar com relativa rapidez a sua frequencia até atingir a estabilidade. Esta fase de estabilidade por sua vez dá ampla ocasiáo de se iniciar outro mecanismo de evoluçáo, que denominamos "modifier shift" (Brieger, 1943). Durante Aste, pela seleçăo de modificadores, os novas homozigotos poderiam ultrapassar a sobrevivencia dos homozigotos originais. Acontecendo tal alteração das sobrevivências, processa-se imediatamente nma tendencia para atingir novo equilibrio, na qual os novos homozigotas tornam-se mais frequentes do que os originais, uma vez que o mecanismo do "modifler shift" afeta apenas as novas homozigotos e não os heterozigotos, poderemos até postular que finalmente a sobrevivência dos primeiros será maior do que aquela e todos as demais genótipos, e isto finalmente causaria a eliminaçăo completa do gen original, como explicado nas formulas para o caso de um valor $\mathbf{R}$ ser maior ou igual e outro menor do que um.

Devemos ainda lembrar que náo é provável que os valores de sobrevivencia sejam idênticos em tôdas as localidades e condiçбes, e no seu trabalho recente e muito importante Wright e Dobzhansky comprovaram este ponto. Assim parece bem passivel, que numa localidade ou numa determinada condiçấo ecológica os valores de sobrevivencia para os homozigotas e heterozigotos de um determinada mutaçáo serão tais que se aumentará automáticamente a frequencia da nova mutaçăo, quando em outros lugares e conđiçбes, a mutaçăo será eliminada. Assim este mecanismo dará uma base para uma evoluçăo divergente partindo de populaçరes e mutaçōes idênticas, porém ocorrendo em localidades ou em condiçós ecologicas diferentes.

Paśsamos agora a discutir a situação em espécies, repraduzidas por autofecundaçăo. Pelo exposto num capitulo anterior sabemos que apenas quando tanto os homozigotos originais como as novos tem uma sobrevivencia menor do que $\mathbf{0 , 5}$, encontraremos uma situaçáo correspondente áquela discutida justamente para espécies com reprodução cruzada. Mas uma sobrevivência tấo pequena das homozigotos originais parece táo pouco provável, que podemos considerar o mecanismo em discussão como de pouca importancia nas espécles autofecundadas. 
Finalmente a pergunta, se há mutações conhecidas onde as heterozigotos sejam mais viáveis que ambos homozigotos, pode ser respondida afirmativamente, apesar do número de casos ser ainda bem pequeno (veja citações em Brieger, 1948). Mas uma vez que uma pequena superioridade dos heterozigotos é difícil de ser constatada, poderemos esperar que êste caso náo seja realmente muito raro. Também pode se prever que gens onde os heterozigotos são mais viáveis devem ser mais raras em espécies reproduzidas por autofecundação do que em espécies com reprodução cruzada, pois apenas nestes últimos a seleção natural favorece tais gens. Porém não entrarei aqui em detalhe nesta discussão, pois o assunto será tratado em outra publicação especializada.

Devemos ainda mencionar outra situação, à qual já fiz referência acima. Já expliquei o efeito, em espécies com reprodução cruzada, da redução do número de individuos nas populações que deve conduzir a uma alteração profunda no modo da reprodução, que passará de um cruzamento livre para uma forma de reproduçáo mista com aumento da autofecundaçáo ou dos acasalamentos consanguíneos. Com isso se dará naturalmente uma modificação dos sistemas de eliminação. Uma vez que em populações cruzadas os gens serăo mantidos quando a sobrevivência de ambos homozigotos fôr apenas menor do que um, quando para isso será necessário em populaçōes autofecundadas uma sobrevivencia menor do que $\mathbf{0 , 5}$, poderemos esperar que em individuos relativamente isolados a eliminação contra os gens menos vláveis torne-se mais intensiva. Assim chegamos a uma explicação matemática do antigo principio de Vavilov, que as espécies perdem em riqueza de gens em regióes geográficas mais afastadas, seja do centro da origem, seja de regiões de maior densidade de distribuição.

Não entraremos aqui em considerações mais detalhadas apesar de não haver dúvida que muitas questões especiais da evolução podem ser ainda explicadas por deduções sôbre a genética em populaçóes.

\section{VIII - RESUMO}

1) O equilíbrio em populações, inicialmente compostas de vários genótipos depende essencialmente de três fatores: a modalidade de reprodução e a relativa viabilidade e fertilidade dos genótipos, e as frequências iniciais.

2) Temos que distinguir a) reprodução por cruzamento 
livre quando qualquer indivíduo da população pode ser cruzado com qualquer outro; b) reprodução por autofecundação, quando cada indivíduo é reproduzido por uma autofecundação; c) finalmente a reprcdução mista, isto é, os casos intermediários onde os indivíduos são em parte cruzados, em parte autofecundados.

3) Populações heterozigotas para um par de gens e sem seleção. Em populações com reprodução cruzada se estabelece na primeira geração um èquilíbrio entre as três genótipos, segundo a chamada regra de Hardy- Weinberg.

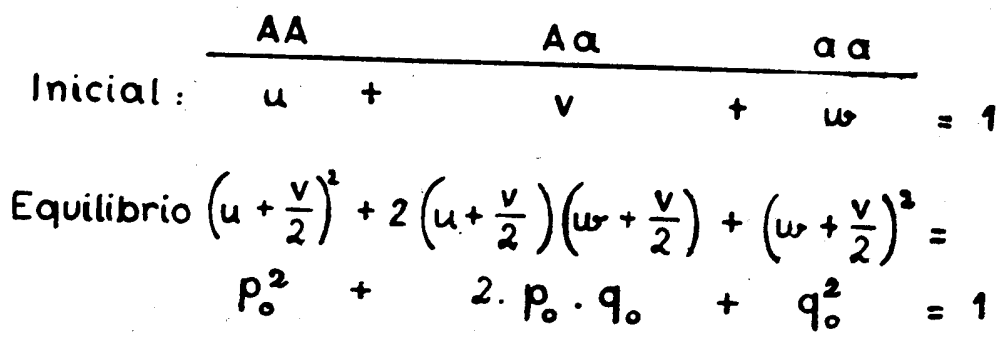

Em populações com autofecundação o equilíbrio será atingido quando estiverem presentes apenas os dois homozigotos, e uma fórmula é dada que permite calcular quantas gerações são necessárias para atingir aproximadamente este resultado.

Frequência

\begin{tabular}{|c|c|c|c|}
\hline Genotipo & Inicial & $m^{\circ}$ Geroçöo & Finol \\
\hline AA & $u$ & $u+\frac{2^{m}-1}{2^{m+1}} v$ & $u+\frac{1}{2} v$ \\
Ao & $v$ & $\frac{2}{2^{m+1}} v$ & - \\
o a & $w$ & $w+\frac{2^{m}-1}{2^{m+1}} v$ & $w+\frac{1}{2} v$ \\
\hline
\end{tabular}

Finalmente, em populações com reprodução mista, obtemos um equilíbrio com valores intermediários, conforme Quadro 1. 
4) Os índices de sobrevivência. Para poder chegar a fórmulas matemáticas simples, é necessárto introduzir índices de sobrevivência para medir a viabilidade e fertilidade dos homozigotos, em relação à sobrevivência dos heterozigotos. Designamos a sobrevivência absoluta de cada um dos três genótipos com $x, y$ e $z$, e teremos então:

\section{$x[A A]: y[A a]: z[a a]$$$
=\frac{x}{y}[A A]: 1[A D]: \frac{z}{y}[a d]
$$$$
=R_{A}[A A]: 1[A a]: R_{a}[a d]
$$

evidente que os índices $R$ poderão ter qualquer valor desde zero, quando haverá uma eliminação completa dos homozigotos, até infinito quando os heterozigotos serão completamente eliminados. Os termas $(1-\mathrm{K})$ de Haldane e (1-S) ou $\mathrm{W}$ de Wright não têm esta propriedade matemática, podendo variar apenas entre zero e um.

E ainda necessário distinguir índices parciais, de acôrdo com a marcha da eliminação nas diferentes fases da ontogenia dos individuos. Teremas que distinguir em primeiro lugar entre a eliminação durante a fase vegetativa e a eliminação na fase reprodutiva. Estas duas componentes são ligadas pela relaçáo matemática.

$$
\mathbf{R}=\mathbf{R V} \cdot \mathbf{R} \mathbf{R}
$$

5) Populações com reprodução cruzada e eliminação. Consideraçōes gerais.

a) O equilibrio final, independente da frequencia inicial dos genes e dos genótipos para valores da sobrevivencia diferentes de um, é atingido quando os gens e os genótipos estão presentes nas proporçס̃es seguintes: (Quadro 2). 


$$
\begin{gathered}
\frac{p_{0}}{q_{0}}=\frac{1-R_{a}}{1-R_{A}} \\
\frac{[A A]}{[A d]}=\frac{\left(1-R_{0}\right)^{2} \cdot R_{A V}}{\left[\left(1-R_{a}\right)\left(1-R_{A}\right)\right.} \\
\left(1-R_{A}\right)^{2} \cdot R_{a A}
\end{gathered}
$$

b) Formulas foram dadas que permitem calcular as trequências dos genótipos em qualquer geração das populações. Não foi tentado obter fórmulas gerais, por processos de integração, pois trata-se de um processo descontínuo, com saltos de uma e outra geraçăo, e de dưração curta.

6) Populações com reprodução cruzada e eliminação.

Podemos distinguir os seguintes casos:

a) Heterosis - (Quadro 3 e Fig. 1).

$$
R_{A}<1 ; R_{a}<1 \text {. }
$$

Inicial:

Final:

$$
\frac{p(A)}{q(a)} \longrightarrow \frac{1-R_{a}}{1-R_{A}}=\frac{\text { posifivo }}{\text { posifivo }}
$$

Os dois gens e assim os três genótipos zigóticos permanecem na população. Quando as frequências iniciais forem maiores do que as do equilíbrio elas serão diminuidas, e quando forem menores, serão aumentadas.

b) Gens recessivos letais ou semiletais. (Quadro 1 e Fig. 2).

$$
R_{A}=1 ; 0 ₹ R_{0}<1
$$

Inicial:

Final:

$\frac{P(A)}{q(a)} \longrightarrow \frac{1-R_{a}}{1-R_{a}}=\frac{\text { positivo }}{\text { zero }}=$ infinito 
O equilibrio será atingido quando o gen, que causa a redução da viabilidade dos homozigotos, for eliminado da população.

c) Gens parcialmente dominantes semiletais. (Quadro 5 e Fig. 3).

$$
\begin{aligned}
& R_{A}>1 ; 0 ₹ R_{Q}<1 \\
& \text { lnicial: } \begin{array}{c}
\text { Equilibrio } \\
\text { biológico }
\end{array} \\
& \frac{p(A)}{g(a)} \rightarrow \frac{\begin{array}{c}
\text { Equllibrio } \\
\text { mofomótico }
\end{array}}{\text { posifivo }} \rightarrow \frac{1-R_{0}}{1-R_{A}}=\frac{\text { posifivo }}{\text { negofivo }} \\
& \text { d) Genes incompatíveis. }
\end{aligned}
$$

$$
\begin{aligned}
& R_{1}>1 ; R_{a}>1 ; R_{1}>R_{a} \\
& \text { Equilibrio } \\
& \text { biológico } \\
& \frac{p(A)}{q(0)} \rightarrow \frac{\text { positivo }}{\text { zoro }} \quad \begin{array}{r}
\text { Equillbrio } \\
\text { molemólico }
\end{array} \\
& \rightarrow \frac{\text { posifivo }}{\text { negofivo }} \rightarrow \frac{\text { zoro }}{\text { negolivo }} \rightarrow \frac{1-R_{R}}{1-R_{A}}=\frac{\text { negolivo. }}{\text { negolivo }}
\end{aligned}
$$

Nestes dois casos devemos distinguir entre o significado matemático e biológico. A marcha da eliminação náo pode chegar até o equilíbrio matemático quando um dos gens alcança antes a frequência zero, isto é, desaparece.

Nos três casos teremos sempre uma eliminação relativamente rápida de um dos gens a com isso do homozigoto ressectivo e dos heterozigotos.

e) Foram discutidos mais dois casos especiais: eliminação reprodutiva diferencial dos dois valores do sexo feminino e masculino, e gens para competição gametofítica. (Quadros 6 e 7 e Figs. 4 a 6 ).

7) População com autofecundação e seleção.

O equilíbrio será atingido quando os genótipos estiverem presentes nas seguintes proporções: (Quadro 8). 


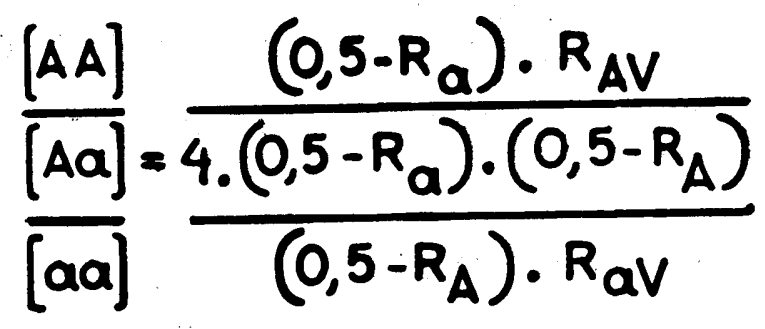

Também foram dadas fórmulas que permitem calcular as proporções genotípicas em cada geração e a marcha geral da eliminação dos genótipos.

8) Casos especiais. Podemos notar que o têrmo $(0,5-R)$ nas fórmulas para as populações autofecundadas ocupa mals ou menos a mesma importância do que o têrmo (1-R) nas fórmulas para as populações cruzadas.

a) Heterosis. (Quadro 9 e Fig. 7).

Quando RA e $R$ a têm valores entre 0 e $\mathbf{0 , 5}$, obtemos o seguinte resultado:

No equilíbrio ambos os gens estão presentes e os três heterozigotos săo mais frequentes do que os homozigotos.

b) Em todos os demais casos, quando $\mathrm{RA}$ e $\mathrm{Ra}$ forem iguais ou maiores do que $\mathbf{0 , 5}$, o equilíbrio é atingido quando estão representados na população apenas os homozigotos mais viáveis e férteis. (Quadro 10).

9) Foram discutidos os efeitos de alterações dos valores da sobrevivência (Fig. 9), do modo de reprodução (Fig. 10) e das frequências intciais dos gens (Fig. 8).

\section{0) Algumas aplicações à genética aplicada..}

Depois de uma discussão mais geral, dois problemas principais foram tratados: a) A homogeneização: Ficou demonstrado que a reprodução por cruzamento livre representa um mecanismo muito ineficiente, e que se deve empregar sempre ou a autofecundação ou pelo menos uma reprodução mista com a maior frequência possível de acasalamentos consanguíneos. Fórmulas e dados (Quadro 11 e 12), permitem a determinação do número de gerações necessárias para obter um grau razoável de homozigotia.

b) Heterosis. Existem dois processos, para a obtenção de um alto grau de heterozigotia e com isso de heterosis: 
a) O método clássico do "inbreeding and outbreeding".

b) O método novo das populaçoes balançadas, baseado na combtnaçăo de gens que quando homozigotos dăo uma menor sobrevivencia do que quando heterozigotas.

11) Algumas consideraçz̃es sôbre a teoria de evolução:

a) Heterosis. Os gens com efelto "heterótico", isto é, nos casos onde as heterozigotas sáo mais vláveis e fértels, do que as homozigotos, oferecem um mecanismo especial de evolução, pois nestes casos a trequencia dos gens, apesar de seu efelto negativo na fase homozigota, tem a sua irequencia aumentada até que seja atingido o valor do equilibria.

b) Gens letais e semiletais recessivos. Foi demonstrado que estes gens devem ser eliminados automaticamente das populaçoes. Porém, ao contrário do esperado, năo săo raras por exemplo em milho e em Drosophila, gens que até hoje foram classificados nesta categoria. Assim, um estudo detalhado torna-se necessario para nesolver se os heterozigotos em multos destes casas năo seráo de maior sobrevivencia do que ambos os homozigotos, isto é; que se trata realmente de genes heteróticas.

c) Gens semiletais parcialmente dominantes. gestes gens serăo sempre eliminados nas populaçōes, e de fato eles săo encontrados apenas raramente.

d) Gens incompatíveis. Såo também geralmente eliminados das populaçoes. Apenas em casas especiais eles podem ter importancia na evoluça, representando um mecanismo de isolamento.

\section{IX - ABSTRACT}

1) The equllibrium in populations, initially composed of various genotypes depends essentially from the mode of reproduction the relative viability and fertility of the competing genotypes, and the initial frequencies.

2) We have to distinguish two main types of sexual reproduction: Cross fertilization or random mating where each individual has equal chances to be fertilized by anj individual of the population, and Self-fertilization where each individum is automatically selfed. Finally we encounter cases of a mixed reproduction where there is no free intercrassing nor an absolute selfing.

3) Populations, heterozygous for one patr of genes and without selection. 
a) In crass fertilized populations equillbrium is reached in acordance with the Hardy-Weinberg rule, in the first generation:

Inicial: $\frac{A A+A a+w a}{u+v}=1$

$$
\begin{aligned}
& \text { Equilibrio }\left(u+\frac{v}{2}\right)^{2}+2\left(u+\frac{v}{2}\right)\left(w+\frac{v}{2}\right)+\left(w+\frac{v}{2}\right)^{2}= \\
& p_{0}^{2}+2 \cdot p_{0} \cdot q_{0}+q_{0}^{2}=1
\end{aligned}
$$

b) In self fertilized populations equilibrium will be reached thermiticialy by the complete elimination of all heterozigotes, but a sufficient approach to equilibrium may be reached quickly:

\section{Frequeincia}

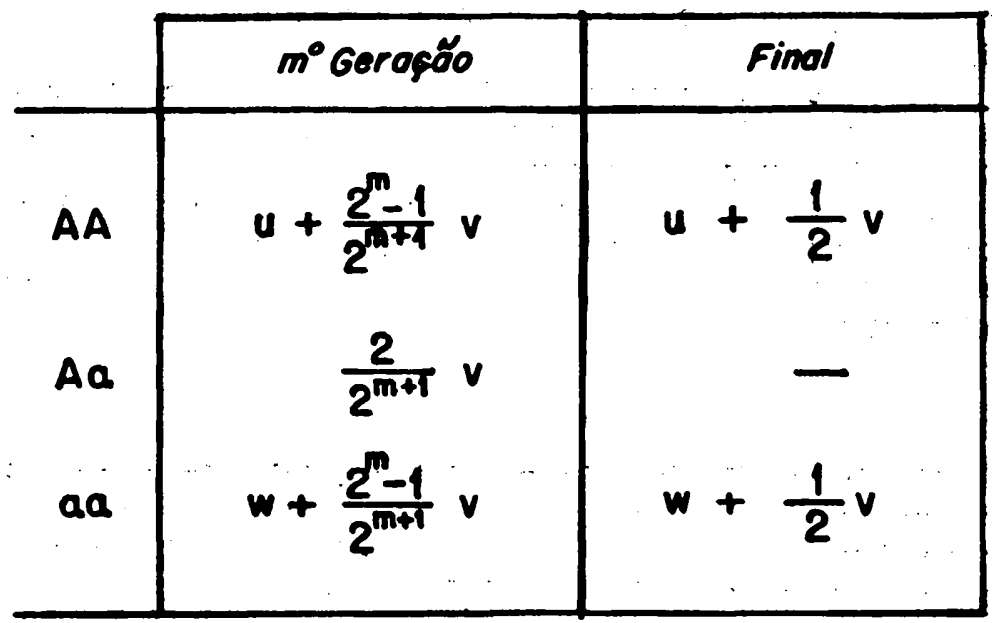

c) In populations with mixed reproduction, the equilibrium depends upon the relative frequencies of crossing and selfing; and the final values for some cases are given in Qüadro 1.

4) Survival Indices - Mathematical formulas are simplifled if we introduce special survival indices for the homozygotes in relation to the survival of the heterozygotes. If we designate the absolve survival values of the three ge- 
notypes $A A, A a$ and $a a$, by $x, y$ and $z$. we may give the following mathematical definition:

$$
\begin{aligned}
& x[A A]: y[A d]: z[a d] \\
= & \frac{x}{y}[A A]: 1\left[A d: \frac{z}{y}[a d]\right. \\
= & R_{A}[A A]: I[A d]: R_{a}[a d]
\end{aligned}
$$

Thus the value of $R$ can have any value between zero, 1. e. complete elimination of homozygotes, and infinite, 1 . e. complete elimination of heterozygotes. The terms (1-K) of Haldane and $(1-S)$ or $W$ of Wright do not have this mathematical property, and may have only values from zero to one.

Evidently, in accordance with the nature of the ellminatory process, we shall have to subdivide these indices of total survival $\mathbf{R}$ into at least two main components: the survival during the vegetative phase and the survival of gametes during the reproduction phase. These two componentes are united by the following equation

$$
\mathbf{R}=\mathbf{R A} \cdot \mathbf{R} \mathbf{R}
$$

5) Populations with random mating and selection..

a) The final equilibrium, which is independent from the Initial gene or genotype frequendies, is reached when the genes and the zygotic genotypes are present in the following proportions: (Quadro 2).

$$
\frac{P_{0}}{Q_{0}}=\frac{1-R_{0}}{1-R_{A}}
$$

$$
\frac{[A A]}{[A 0]}=\frac{\left(1-R_{0}\right)^{2} \cdot R_{A V}}{[00]}=\frac{2\left(1-R_{a}\right)\left(1-R_{A}\right)}{\left(1-R_{A}\right)^{2} \cdot R_{a A}}
$$


b) Formulas are given which permit the calculus of frequencies in intermediate generations.

6) Discussion of special cases.

a) Heterotic Genes. (Quadro 3 and Fig. 1).

$$
R_{A}<1 ; R_{a}<1
$$

Inicial:

Final:

$$
\frac{p(A)}{q(a)}
$$$$
\frac{1-R_{a}}{1-R_{A}}=\frac{\text { positivo }}{\text { posifivo }}
$$

At equilibrium both genes remain present in the population, and their frequency will be increased or decreased whenever the initial frequencies were bigger or smaller than the values expected at equilibrium. Fig. 2).

b) Letals or semiletal, recessives genes. (Quadro 4 and

$$
R_{A}=1 ; 0 \approx R_{0}<1
$$

Iniciol:

Final:

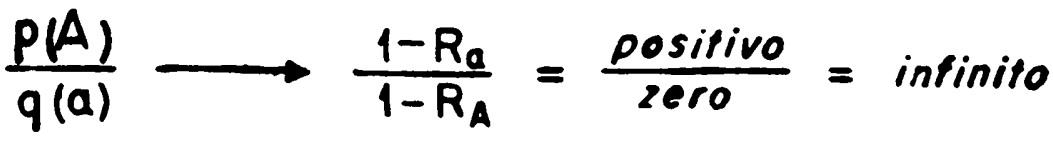

Equilibrium will be reached when the gene which causes the reduction of viability or fertility of homozigotes, is ellminated from the population. Fig. 3).

c) Semiletals, and parcially dominant genes. (Quadro 5 and

$$
R_{A}>1 ; O \sum R_{e}<1
$$

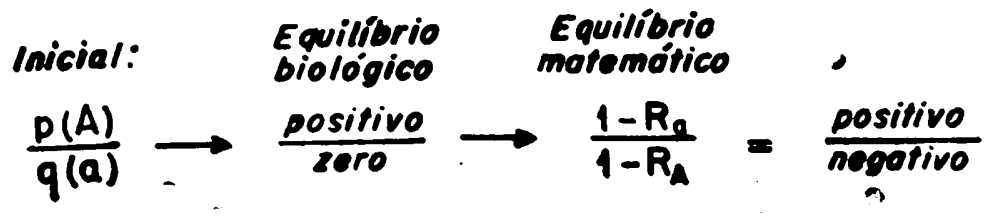


d) Incompatible Genes.

$$
\begin{aligned}
& R_{1}>1 ; R_{a}>1 ; R_{1}>R_{a} \\
& \text { Equilibrio } \\
& \text { biológice } \\
& \frac{P(A)}{q(a)} \rightarrow \frac{\text { posifivo }}{\text { zero }} \\
& \rightarrow \frac{\text { posilivo }}{\text { negofivo }} \rightarrow \frac{\text { zero }}{\text { negorivo }} \rightarrow \frac{1-R_{R}}{1-R_{A}}=\frac{\text { negotivo. }}{\text { negofivo }}
\end{aligned}
$$

In these two cases we have to distinguish between the blological and the mathematical equilibrium. The first will be reached when one of the genes has a frequency equal to zero, while negative values can have a mathematical meaning only. Thus biological equilibrium will be reached with the elimination of the gene which causes a relatively lower viability of the respective homozygotes.

Howenwer we must note still one exception in the last case of incompatible genes: When both genes have the same initial frequency and when the respective survival values are also equal and larger than one, both the genes will remain in the population, and the homozygotes will become more frequent than the heterozygotes, thus furnishing an isolating mechanisme.

e) Two special cases were discussed in some detail: differential elimination in the two sexes, and gametophite compettition. (Quadro 6 e 7 e Fig. 4 a 6).

7) Populations with self-fertilization.

a) Equilibrium will be reached when the three genotypes are present in the following proportions. (Quadro 8).

$$
\frac{[A A]}{[A a]}=\frac{\left(0,5-R_{a}\right) \cdot R_{A V}}{4 \cdot\left(0,5-R_{a}\right) \cdot\left(0,5-R_{A}\right)}
$$


b) Formulas are given which permit the determination of genotype frequencies in intermediate generations.

\section{8) Special cases.}

We may say that, in a general way, the diferences (1-R) in the formulas for populations with randon mating anci $(0.5-R)$ in selfed populations, occupy corresponding positions.

a) Heterotic Genes. (Quandro 9 and Fig. 7).

RA menor do que 0,5

$\mathrm{Ra}$ menor do que 0,5

At equilibrium both genes remain in the populations and the three zygotic genotypes reach standard values, independent from the initial frequencies.

b) In all other cases, 1. e. where one or both values of the survival indices are equal or bigger than 0,5 , the following situation arises: When the survival values for both homozygotes are equal, equilibrium will be reached when the population contains only these homozygotes with identical. When the survival values are different, equilibrium will be reached when only the homozygotes of the genotype whith the higher survival value remain in the population, while the other homozygotes and all heterozygotes have disappeared.

9) The result of variations in the initial gene frequencies (Fig. 8), of sudden changes in survival values (Fig. 9) and of the mode of reproduction (Fig. 10) are discussed in some detail.

\section{0) References to problems of applied genetics.}

After some general observations on population genetics and applied genetics, two problems were discussed in some detall:

a) Homogenization: - Formulas and data (Quadros $11 €$ 12) are given which show that random mating systeme are very inefficient means to obtain homozigous populations, and that either selfing or some system of consanguineous matings should always be applied. These tables may also serve to obtain estimates as to the number of inbred generations necessary to obtain certain levels of homozygosis. 
b) Heterosis may evidently be obtained by the classical method of "inbreeding and outbreeding" or by the establishement of balanced populations containing genes with a heterotic effect, both with regards to their general vigor and productivity, as to their survival values.

\section{1) Considerations on the evolutionary mechanismes.}

a) The importarice of heterutic survival values is discussed, and references are made to a special publication on the subject (Brieger, 1948).

b) Recessive lethals and semilethals. It is evident from the discussions that genes of this nature should be eliminated from the populations. But observations in corn, and in Drosophila, leave little doubt that genes such as tassel-seed, barrenstalk, numerous types of defective seeds, etc., are relatively frequent in populations which have not been subjected previously to a scientific selection. In order to explain this discrepancy, new studies are necessary in oder to find out whether survival in homozygotes, are not at the same time heterotic for the survival values.

c) Dominant semilethals - It must be expected that these genes are speedily eliminated from the populations, and in fact, they are rare in natural populations.

b) Incompatible genes - These genes also should be very rare, except perhaps in the special case where they serve to establish an isolating mechanism.Very litlle is known howewer with respect of them.

\section{LTTERATURA}

BATEMAN, A. J. - 1947 - Contamination of seed crops.

I. Insect Pollination. - Jour. Genetics 48: 257 - 275.

BATEMAN, A. J. - 1947 - Contamination of seed crops. II. Wind Pollination. - Heredity 1: $235-246$.

BRIEGER, F. G. - 1935 - Self and Crosspollination in Zea Mayz and Nicotiana Tabacum. - 6. Iternat. Bot. Congress Amsterdam pp. $51-53$. 
BRIEGER F. G. - 1943 - Consideraçס̌es sóbre o mecanismo da evoluçăo. -- Anais da E. S. A. "Luiz de Queiroz" 1: $175-211$.

BRIFGER, F.G. - 1945 - A açăo dos gens gametofíticas, com referencia especial ao milho. - Anais da E. S. A. "Luiz de Quelroz" 3: 26! - 297.

BRIEGER, F. G. - 1947 - A determinaçăo dos números de individuos mínimos necessários na experimentação genética. - Anais da E. S. A. "Luiz de Queiroz" 4: 217 - 262.

BRIEGER, F. G. - 1948 - Heterasis as an evolutionary mechanism. - Pallanza. Symposium (in press).

DOBZHANSKY, TH - 1947 - Genetics and the origin of species. - Columbia Univ. Press. 446 pp.

DOBZHANSKY, TH. and

EAST, E. M. and D. F. JONES - 1918 - Inbreeding and outbreeding - Phlladelphia, Lipincott Co. 285 pp.

HALDANE, J. B. S. - 1926 - A mathematical theory of natural and artificial selection. Part III. - Trans. Cambr. Phil. Soc. 23: : $19-41$.

GURGEL, J. T. A. - 1945

HOGBEN, L. - 194.6 - An introduction to mathematical genetics. - New York - Norton Co. 260 pp.

KRUG, C. A.

MATHER, $\mathrm{K}$.

PATTERSON, J. T. - 1947 - Studies in the genetics of Drosophila V - Isolating Mechanism. - Univ. Texas Publ. 4720.

STERN, C. - 1943 - The Hardy-Weinberg Larv. - A. Nat. 97: $137-138$.

WRIGHT, S. - 1139 - Statistical Genetics in Relation to Evolution. - Paris, Hermann e Cia. Editeurs: 63 pp.

WRIGHT, S. and ITH. DOBZHANSKY - 1946 - Genetics of Natural Populettions XII. Experimental reproductions of some of the changes caused by natural selection in certain populations of Drosophila pseudoobscura. Genetics 31: $125-156$. 


\section{QUADRO 1}

Combinação de Cruzamento livre e Autofecundação

\begin{tabular}{|c|c|c|c|c|c|}
\hline \multicolumn{2}{|c|}{ Proporçáo } & \multirow{2}{*}{ Geração } & \multirow{2}{*}{$\mathbf{A A}$} & \multirow{2}{*}{ Aa } & \multirow{2}{*}{ aa } \\
\hline $\begin{array}{c}\text { Cruzamento } \\
\text { livre }\end{array}$ & $\begin{array}{l}\text { Autofe- } \\
\text { cundaçắo }\end{array}$ & & & & \\
\hline 1,0 & - & 1 & 25,00 & 50,00 & 25,00 \\
\hline 0,9 & 0,1 & 3 & 26,32 & 47,37 & 26,32 \\
\hline 0,7 & 0,3 & 5 & 29,41 & 41,18 & 29,41 \\
\hline 0,5 & 0,5 & 8 & 33,33 & $\mathbf{3 3 , 3 3}$ & 33,33 \\
\hline 0,3 & 0,7 & 10 & 38,46 & 23,08 & 38,46 \\
\hline 0,1 & 0,8 & 13 & 45,45 & 9,09 & 45,45 \\
\hline - & 1,0 & inf. & 50,00 & - & 50,00 \\
\hline
\end{tabular}




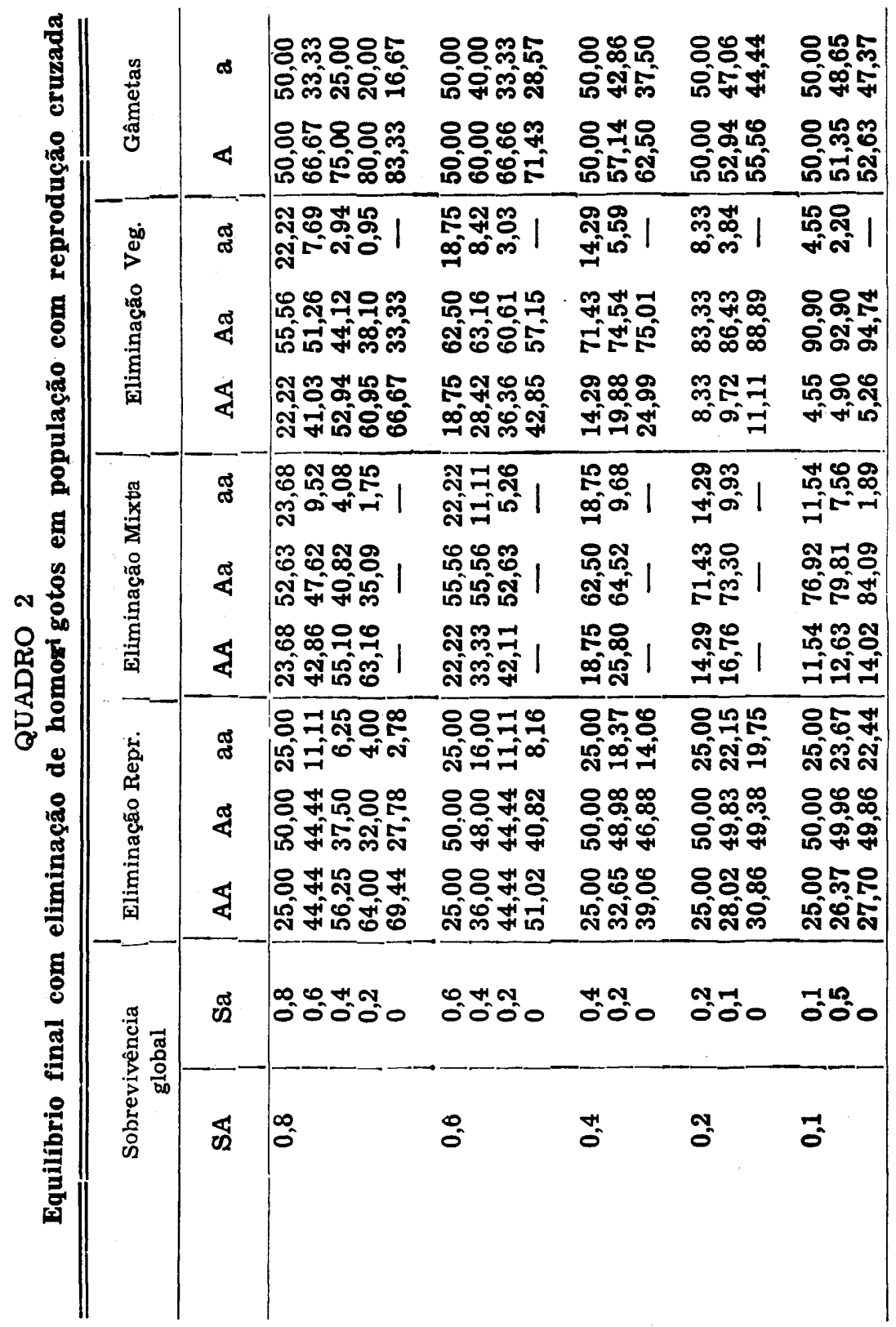


Resultado da eliminação diferencial de homozigotos em populações com reprodução cruzada

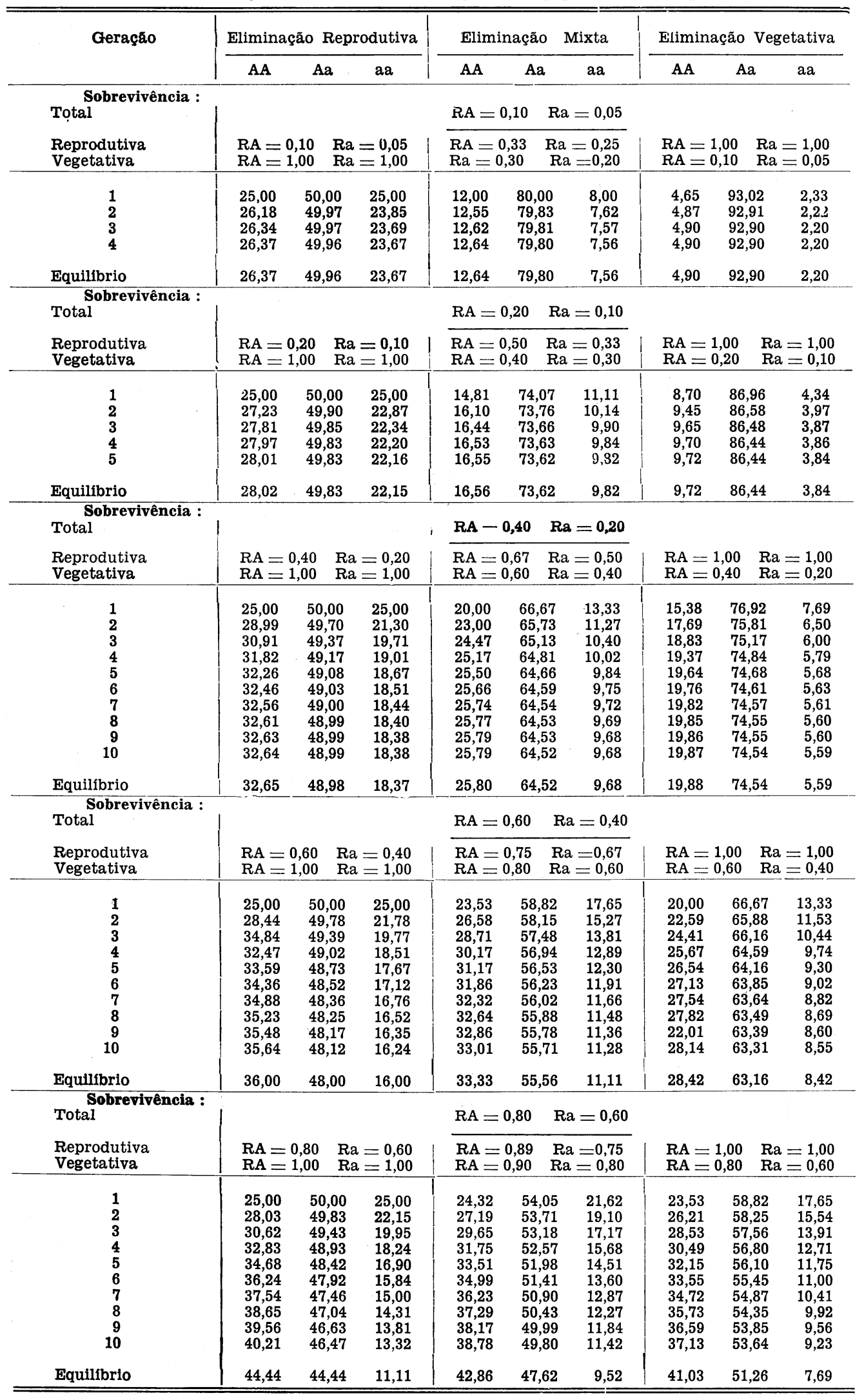


Efeito da eliminação de um dos homozigotos em populações com reprodução cruzada

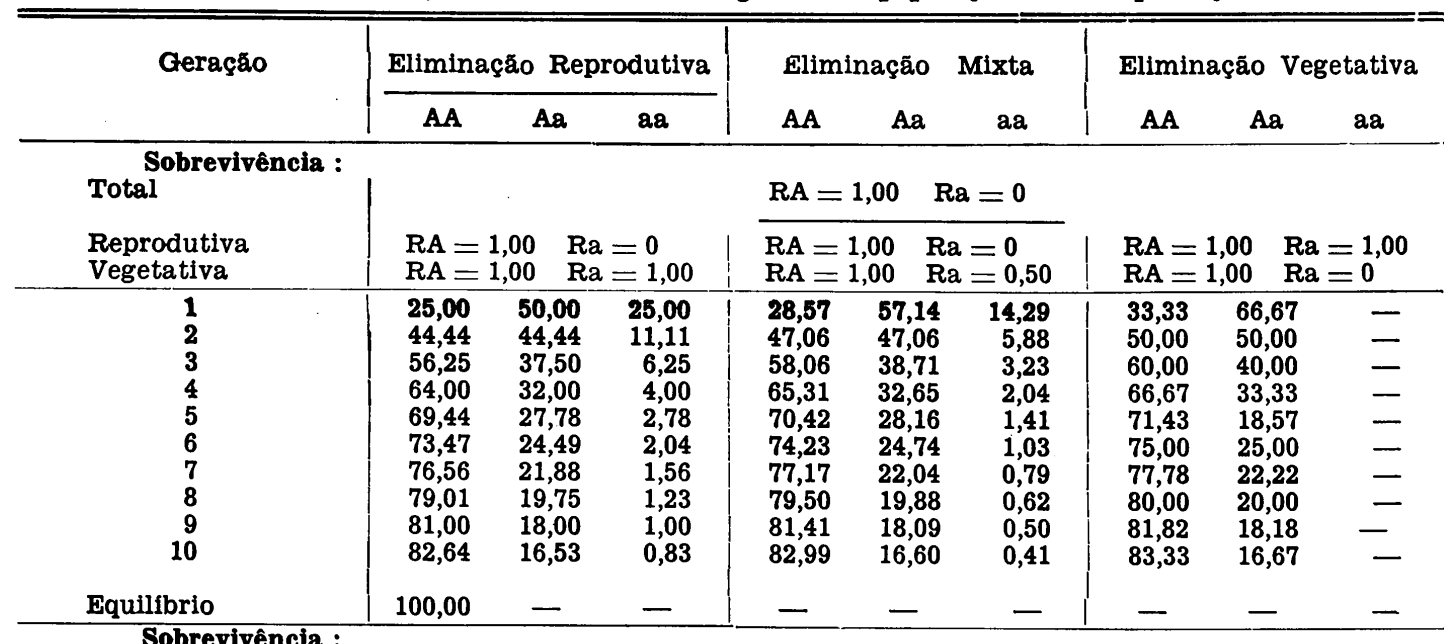

Total

\section{Sobrevivência :}

Reprodutiva

Vegetativa

1
2
3
4
5
6
7
8
9
10

Equilibrio

Total

\section{Sobrevivência}

Reprodutiva

Vegetativa

1
2
3
4
5
6
7
8
9
10

Equilibrio Total

Sobrevivência :

rodutive

Vegetativa

\begin{tabular}{|c|c|c|c|c|c|c|c|c|c|}
\hline 1 & 25,00 & 50,00 & 25,00 & 25,64 & 51,28 & 23,08 & 26,32 & 52,63 & 21.05 \\
\hline 2 & 27,70 & 49,86 & 22,43 & 28,34 & 51,01 & 20.65 & 29,00 & 52,21 & 18,79 \\
\hline 3 & 30,36 & 49,48 & 20,16 & 30,98 & 50,50 & 18,52 & 31,64 & 51,56 & 16,80 \\
\hline 4 & 32,96 & 48,91 & 18,13 & 33,57 & 49,81 & 16,62 & 34,20 & 50,75 & 15.0 ? \\
\hline 5 & 35,49 & 48,18 & 16,33 & 36,08 & 48,98 & 14,94 & 36,69 & 49,81 & 13,50 \\
\hline 6 & 37,92 & 47,32 & 14,75 & 38,49 & 48,03 & 13,48 & $\begin{array}{l}39,08 \\
\end{array}$ & 48,76 & 12,16 \\
\hline 7 & 40,27 & 46,38 & 13,34 & 40,82 & 47,01 & 12.17 & 41,38 & 47,66 & 10,96 \\
\hline 8 & 42,50 & 45,39 & $12, \mathrm{i} 1$ & 43,02 & 45,95 & 11,03 & 43,56 & 46,50 & 9,94 \\
\hline 1 & 44,64 & 44,35 & 11,01 & 45,14 & 44,84 & 10,02 & 45,65 & 45,35 & 9,00 \\
\hline 10 & 46,66 & 43,30 & 10,04 & 47,13 & 43,74 & 9,13 & 47,62 & 44,19 & 3,19 \\
\hline io & 100,00 & - & - & - & - & - & - & - & _ \\
\hline
\end{tabular}

\begin{tabular}{|c|c|c|}
\hline \multicolumn{3}{|c|}{$\begin{array}{l}\mathrm{RA}=1,00 \quad \mathrm{Ra}=0,20 \\
\mathrm{RA}=1,00 \mathrm{RRa}=1,00\end{array}$} \\
\hline $\begin{array}{l}25,00 \\
39,06 \\
49,59 \\
57,34 \\
63,15 \\
67,64 \\
71,19 \\
74,05 \\
76,41 \\
78,38\end{array}$ & $\begin{array}{l}50,00 \\
46,88 \\
41,66 \\
36,77 \\
32,63 \\
29,21 \\
26,37 \\
24,00 \\
22,01 \\
20,30\end{array}$ & $\begin{array}{r}25,00 \\
14,06 \\
8,75 \\
5,89 \\
4,22 \\
3,15 \\
2,44 \\
1,95 \\
1,58 \\
1,31\end{array}$ \\
\hline 100,00 & - & - \\
\hline
\end{tabular}

$\mathrm{RA}=1,00 \quad \mathrm{Ra}=0,20$

$\overline{\mathrm{RA}=1,00} \mathrm{Ra}=0,50 \quad \mathrm{RA}=1,00 \quad \mathrm{Ra}=1,00$

$\mathrm{RA}=1,00 \quad \mathrm{Ra}=0,40 \quad \mathrm{RA}=1,00 \quad \mathrm{Ra} \equiv 0,20$

\begin{tabular}{lll|lll}
$\mathbf{2 9 , 4 1}$ & $\mathbf{5 8 , 8 2}$ & 11,77 & 31,25 & $\mathbf{6 2 , 5 0}$ & $\mathbf{6 , 2 5}$ \\
$\mathbf{4 2 , 6 6}$ & $\mathbf{5 1 , 2 0}$ & $\mathbf{6 , 1 4}$ & $\mathbf{4 4 , 0 1}$ & $\mathbf{5 2 , 8 1}$ & $\mathbf{3 , 1 7}$ \\
$\mathbf{5 2 , 2 9}$ & $\mathbf{4 4 , 0 1}$ & $\mathbf{3 , 7 0}$ & $\mathbf{5 3 , 3 0}$ & $\mathbf{4 4 , 8 6}$ & $\mathbf{1 , 8 4}$ \\
$\mathbf{5 9 , 4 4}$ & $\mathbf{3 8 , 1 2}$ & $\mathbf{2 , 4 4}$ & $\mathbf{6 0 , 1 7}$ & $\mathbf{3 8 , 5 9}$ & $\mathbf{1 , 2 4}$ \\
$\mathbf{6 4 , 7 9}$ & $\mathbf{3 3 , 4 8}$ & $1, \mathbf{7 3}$ & $\mathbf{6 5 , 3 6}$ & $\mathbf{3 3 , 7 7}$ & $\mathbf{0 , 8 7}$ \\
$\mathbf{6 8 , 9 4}$ & $\mathbf{2 9 , 7 7}$ & 1,28 & $\mathbf{6 9 , 3 9}$ & $\mathbf{2 9 , 9 7}$ & $\mathbf{0 , 6 4}$ \\
$\mathbf{7 2 , 2 5}$ & $\mathbf{2 6 , 7 6}$ & $\mathbf{0 , 9 9}$ & $\mathbf{7 2 , 6 1}$ & $\mathbf{2 6 , 8 9}$ & $\mathbf{0 , 5 0}$ \\
$\mathbf{7 4 , 9 3}$ & $\mathbf{2 4 , 2 8}$ & $\mathbf{0 , 7 9}$ & $\mathbf{7 5 , 2 2}$ & $\mathbf{2 4 , 3 8}$ & $\mathbf{0 , 4 0}$ \\
$\mathbf{7 7 , 1 4}$ & $\mathbf{2 2 , 2 2}$ & $\mathbf{0 , 6 4}$ & $\mathbf{7 7 , 3 9}$ & $\mathbf{2 2 , 2 9}$ & $\mathbf{0 , 3 2}$ \\
$\mathbf{7 9 , 0 1}$ & $\mathbf{2 0 , 4 6}$ & $\mathbf{0 , 5 3}$ & $\mathbf{7 9 , 2 2}$ & $\mathbf{2 0 , 5 2}$ & $\mathbf{0 , 2 6}$
\end{tabular}

$\mathrm{RA}=1,00 \quad \mathrm{Ra}=\mathbf{0 , 5 0}$

$\overline{\mathrm{RA}=1,00} \quad \mathrm{Ra}=1,00 \quad \mathrm{RA}=1,00 \quad \mathrm{Ra}=1,00$

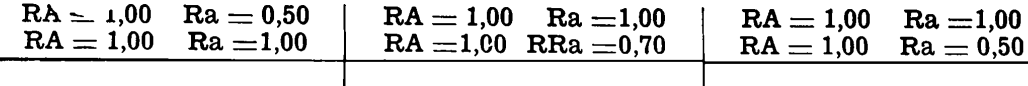

\begin{tabular}{lll|lll|lll}
25,00 & 50,00 & 25,00 & 27,03 & 54,05 & 18,92 & 28,57 & 57,14 & 19,29
\end{tabular}

\begin{tabular}{rrr|rrr|rrr}
32,65 & $\mathbf{4 8 , 9 8}$ & $\mathbf{2 5 , 0 0}$ & $\mathbf{2 7 , 0 3}$ & $\mathbf{5 4 , 0 5}$ & $\mathbf{1 8 , 9 2}$ & $\mathbf{2 8 , 5 7}$ & $\mathbf{5 7 , 1 4}$ & $\mathbf{1 9 , 2 9}$ \\
$\mathbf{3 9}, 59$ & $\mathbf{4 6 , 6 6}$ & 13,75 & $\mathbf{4 1 , 5 5}$ & $\mathbf{5 1 , 8 4}$ & $\mathbf{1 3 , 6 1}$ & $\mathbf{3 5 , 9 5}$ & $\mathbf{5 3 , 9 3}$ & $\mathbf{1 0 , 1 1}$ \\
$\mathbf{4 5}, 65$ & $\mathbf{4 3 , 8 3}$ & 10,52 & $\mathbf{4 8 , 6 7}$ & $\mathbf{1 0 , 0 4}$ & $\mathbf{4 2 , 5 1}$ & $\mathbf{5 0 , 1 0}$ & $\mathbf{7 , 3 8}$
\end{tabular}

\begin{tabular}{rrr|rrr|r|rrr|}
$\mathbf{4 5 , 6 5}$ & 43,83 & 10,52 & $\mathbf{4 7 , 1 4}$ & $\mathbf{4 5 , 2 6}$ & $\mathbf{7 , 6 0}$ & $\mathbf{4 8 , 1 8}$ & $\mathbf{4 6 , 2 6}$ & $\mathbf{5 , 5 5}$
\end{tabular}

\begin{tabular}{rrr|rrr|rrr|r}
$\mathbf{5 0 , 8 6}$ & $\mathbf{4 0 , 9 1}$ & $\mathbf{8 , 2 3}$ & $\mathbf{5 2 , 1 5}$ & $\mathbf{4 1 , 9 5}$ & $\mathbf{5 , 9 0}$ & $\mathbf{5 3 , 0 4}$ & $\mathbf{4 2 , 6 7}$ & $\mathbf{4 , 2 9}$
\end{tabular}

\begin{tabular}{lll|lll|lll}
$\mathbf{5 5 , 3 1}$ & $\mathbf{3 8 , 1 2}$ & $\mathbf{6 , 5 7}$ & $\mathbf{5 6 , 4 2}$ & $\mathbf{3 8 , 8 9}$ & $\mathbf{4 , 6 9}$ & $\mathbf{5 7 , 1 9}$ & $\mathbf{3 9 , 4 1}$ & $\mathbf{3 , 4 0}$
\end{tabular}

\begin{tabular}{lll|lll|lll}
$\mathbf{5 9 , 1 3}$ & $\mathbf{3 5 , 5 3}$ & $\mathbf{5 , 3 4}$ & $\mathbf{6 0 , 0 9}$ & $\mathbf{3 6 , 1 1}$ & $\mathbf{3 , 8 0}$ & $\mathbf{6 0 , 7 5}$ & $\mathbf{3 6 , 5 0}$ & $\mathbf{2 , 7 4}$ \\
$\mathbf{6 2 , 4 2}$ & $\mathbf{3 3}, \mathbf{1 7}$ & $\mathbf{4 , 4 1}$ & $\mathbf{6 3 , 2 6}$ & $\mathbf{3 3 , 6 1}$ & $\mathbf{3 , 1 3}$ & $\mathbf{6 3 , 8 3}$ & $\mathbf{3 3 , 9 2}$ & $\mathbf{2 , 2 5}$
\end{tabular}

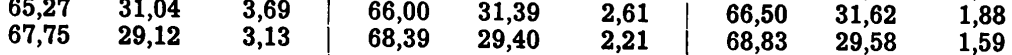

100,00

68,39
$-\quad-\quad-$

68,83

$\mathrm{RA}=1,00 \quad \mathrm{Ra}=0,80$

$\begin{array}{ll}\mathrm{RA}=1,00 & \mathrm{Ra}=0,89\end{array} \mathrm{RA}=1,00 \quad \mathrm{Ra}=1,00$

\begin{tabular}{ll|ll|ll}
$\mathrm{RA}=1,00$ & $\mathrm{Ra}=0,80$ & $\mathrm{RA}=1,00$ & $\mathrm{Ra}=0,89$ & $\mathrm{RA}=1,00$ & $\mathrm{Ra}=1,00$ \\
$\mathrm{RA}=1,00$ & $\mathrm{Ra}=1,00$ & $\mathrm{RA}=1,00$ & $\mathrm{Ra}=0,90$ & $\mathrm{RA}=1,00$ & $\mathrm{Ra}=\mathbf{0 , 8 0}$
\end{tabular} 


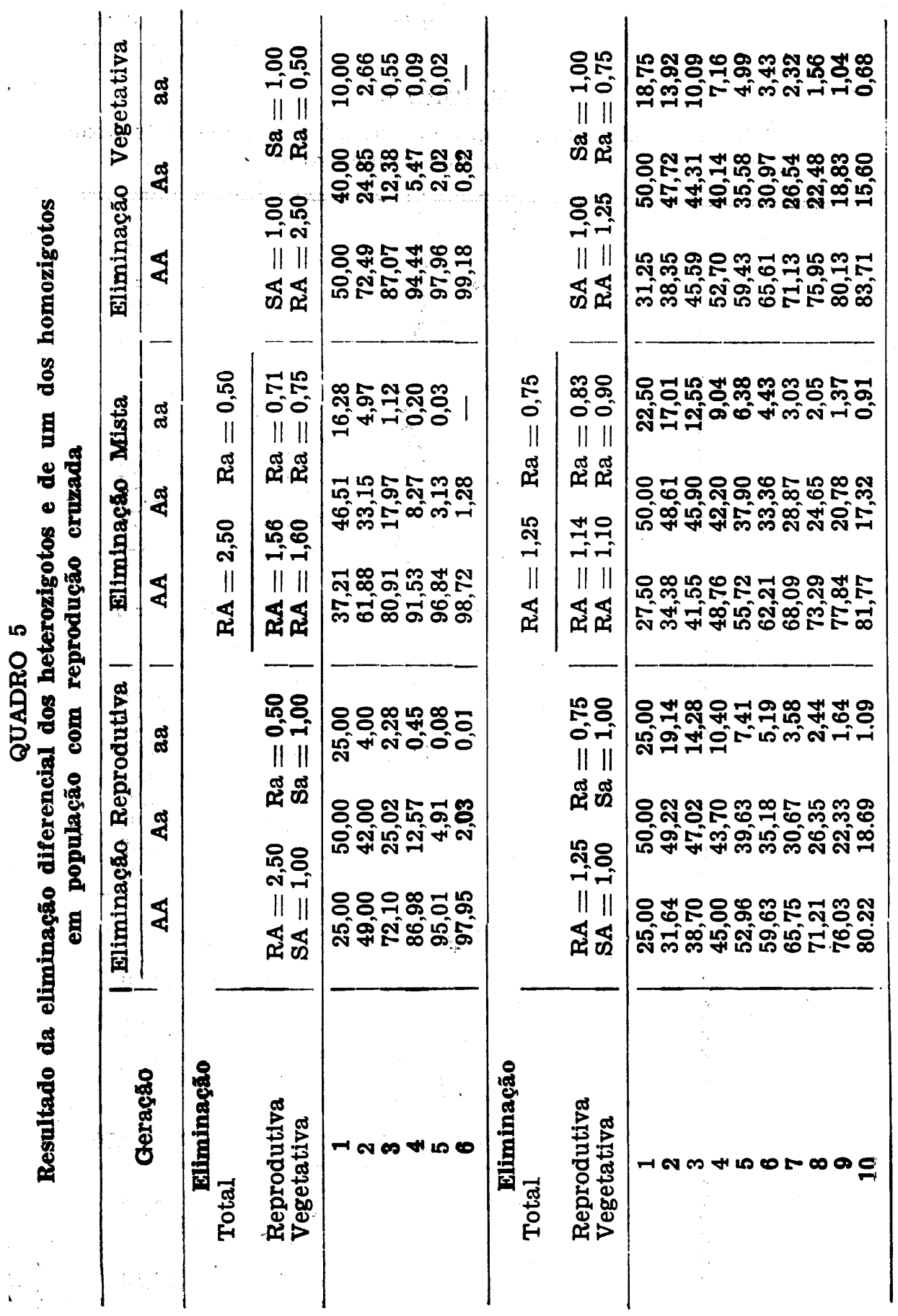




\section{QUADRO 6}

Efeito da eliminação reprodutiva, diferente nos dois sexos de um dos homozigotos

\begin{tabular}{|c|c|c|c|}
\hline Geração & $\mathrm{AA}$ & Aa & aa \\
\hline \multirow[b]{2}{*}{$\begin{array}{r}1 \\
2 \\
3 \\
4 \\
5 \\
6 \\
7 \\
8 \\
9 \\
10\end{array}$} & $\mathbf{S} q=\mathbf{0 , 5 0}$ & & $\mathbf{s} \delta=\mathbf{0}$ \\
\hline & $\begin{array}{l}25,00 \\
38,10 \\
48,15 \\
55,73 \\
61,52 \\
66,06 \\
69,68 \\
72,63 \\
75,07 \\
77,12 \\
\end{array}$ & $\begin{array}{l}50,00 \\
47,62 \\
42,59 \\
37,89 \\
33,85 \\
30,45 \\
27,59 \\
25,19 \\
23,15 \\
22,40\end{array}$ & $\begin{array}{r}25,00 \\
14,28 \\
9,26 \\
6,38 \\
4,63 \\
3,49 \\
2,72 \\
2,18 \\
1,78 \\
1,48\end{array}$ \\
\hline \multirow[b]{2}{*}{$\begin{array}{r}1 \\
2 \\
3 \\
4 \\
5 \\
6 \\
7 \\
8 \\
9 \\
10\end{array}$} & $\mathbf{s} q=1,00$ & & $\mathbf{s} \delta=\mathbf{0}$ \\
\hline & $\begin{array}{l}25,00 \\
33,33 \\
40,83 \\
47,06 \\
52,26 \\
56,64 \\
60,35 \\
63,52 \\
66,26 \\
68,64\end{array}$ & $\begin{array}{l}50,00 \\
50,00 \\
46,67 \\
43,39 \\
40,24 \\
37,36 \\
34,75 \\
3,41 \\
30,32 \\
28,44\end{array}$ & $\begin{array}{r}25,00 \\
16,67 \\
12,50 \\
9,55 \\
7,50 \\
6,00 \\
4,90 \\
4,07 \\
3,42 \\
2,92\end{array}$ \\
\hline \multirow[b]{2}{*}{$\begin{array}{l}1 \\
2 \\
3 \\
4 \\
5\end{array}$} & $\mathbf{s}$ 우 $=1,00$ & & $\mathbf{s} \delta=0,20$ \\
\hline & $\begin{array}{l}25,00 \\
31,25 \\
37,22 \\
42,50 \\
47,14\end{array}$ & $\begin{array}{l}50,00 \\
50,00 \\
47,98 \\
45,64 \\
43,21\end{array}$ & $\begin{array}{r}25,00 \\
18,75 \\
14,80 \\
11,86 \\
9,65\end{array}$ \\
\hline \multirow[b]{2}{*}{$\begin{array}{l}1 \\
2 \\
3 \\
4 \\
5\end{array}$} & $\mathbf{S} Q=1,00$ & & $\mathbf{s} \delta=\mathbf{0 , 5 0}$ \\
\hline & $\begin{array}{l}25,00 \\
28,57 \\
32,14 \\
35,54 \\
38,76\end{array}$ & $\begin{array}{l}50,00 \\
50,00 \\
49,29 \\
48,29 \\
47,10\end{array}$ & $\begin{array}{l}25,00 \\
21,43 \\
18,57 \\
16,17 \\
14,13\end{array}$ \\
\hline
\end{tabular}




\section{QUADRO 7}

Eliminação gonofásica (gametofítica)

\begin{tabular}{|c|c|c|c|c|c|c|}
\hline \multirow[t]{2}{*}{ Geração } & \multicolumn{3}{|c|}{$\begin{array}{l}\text { Eliminaçáo em um } \\
\text { dos sexas }\end{array}$} & \multicolumn{3}{|c|}{$\begin{array}{l}\text { Eliminação em ambas } \\
\text { os sexos }\end{array}$} \\
\hline & $\overline{\mathrm{AA}}$ & Aa & aa & $\overline{\mathbf{A A}}$ & Aa & aa \\
\hline & \multicolumn{3}{|c|}{$\mathrm{Ra}=\mathbf{0 , 2 0}$} & \multicolumn{3}{|c|}{$\mathrm{Ra}=0,20$} \\
\hline 1 & 41,67 & $5 \overline{0,00}$ & 8,33 & 69,44 & 27,78 & 2,78 \\
\hline 2 & 60,61 & 36,36 & 3,03 & 92,46 & 7,40 & 2,78 \\
\hline 3 & 75,50 & 23,49 & 1,01 & 98,41 & 1,57 & 0,01 \\
\hline 4 & 81,84 & 17,63 & 0,53 & 99,68 & 0,32 & - \\
\hline 5 & $\mathbf{8 8 , 8 2}$ & 10,99 & 0,19 & 99,94 & 0,06 & - \\
\hline 6 & 93,20 & 6,74 & 0,07 & & & \\
\hline 7 & 95,88 & 4,09 & 0,02 & & & \\
\hline 8 & 97,52 & 2,48 & - & & & \\
\hline 9 & $\mathbf{9 8 , 5 0}$ & 1,50 & - & & & \\
\hline 10 & 99,10 & 0,90 & - & & & \\
\hline & \multicolumn{3}{|c|}{$\mathrm{Ra}=0,50$} & \multicolumn{3}{|c|}{$\mathrm{Ra}=\mathbf{0 , 5 0}$} \\
\hline 1 & 33,33 & 50,00 & 16,67 & 40,00 & 40,00 & 20,00 \\
\hline 2 & 42,98 & 46,05 & 10,96 & 61,54 & 30,77 & 7,69 \\
\hline 3 & 52,49 & 40,55 & 6,96 & 78,05 & 19,51 & $2 ; 44$ \\
\hline 4 & 61,30 & 34,41 & 4,29 & 88,28 & 11,03 & 0,69 \\
\hline 5 & 69,04 & 28,36 & 2,59 & 93,94 & 5,87 & 0,18 \\
\hline 6 & 75,61 & 22,85 & 1,54 & 96,92 & 3,03 & 0,05 \\
\hline 7 & 81,01 & 18,10 & 0,89 & 98,44 & 1,54 & 0,01 \\
\hline 8 & 85,34 & 14,14 & 0,52 & 99,22 & 0,78 & - \\
\hline 9 & 89,09 & $10 ; 63$ & 0,28 & 99,61 & 0,39 & - \\
\hline 10 & 91,69 & 8,15 & 0,16 & 99,80 & 0,20 & - \\
\hline & \multicolumn{3}{|c|}{$\mathrm{Ra}=0,80$} & \multicolumn{3}{|c|}{$\mathrm{Ra}=0,80$} \\
\hline & 27,78 & 50,00 & 22,22 & 30,86 & 49,38 & $19 ; 75$ \\
\hline 2 & 30,76 & 49,54 & 19,60 & 37,18 & 47,59 & 15,23 \\
\hline 3 & 33,85 & 48,79 & 17,37 & 43,74 & 44,79 & $1 \mathrm{I}, 47$ \\
\hline 4 & 37,00 & 47,77 & 15,23 & 50,33 & 41,23 & 8,44 \\
\hline 5 & 40,22 & 46,50 & 13,28 & 56,73 & 37,18 & 6,09 \\
\hline 6 & 43,46 & 45,02 & 11,52 & 62,80 & 32,93 & 4,27 \\
\hline 7 & 46,70 & 43,36 & 9,94 & 68,36 & 28,67 & 2,97 \\
\hline 8 & 49,91 & 41,54 & 8,54 & 73,35 & 24,61 & 2,04 \\
\hline 9 & 53,08 & 39,62 & 7,30 & 77,75 & 20,87 & 1,38 \\
\hline 10 & 56,17 & 37,61 & 6,22 & 81,56 & 17,51 & 0,93 \\
\hline
\end{tabular}




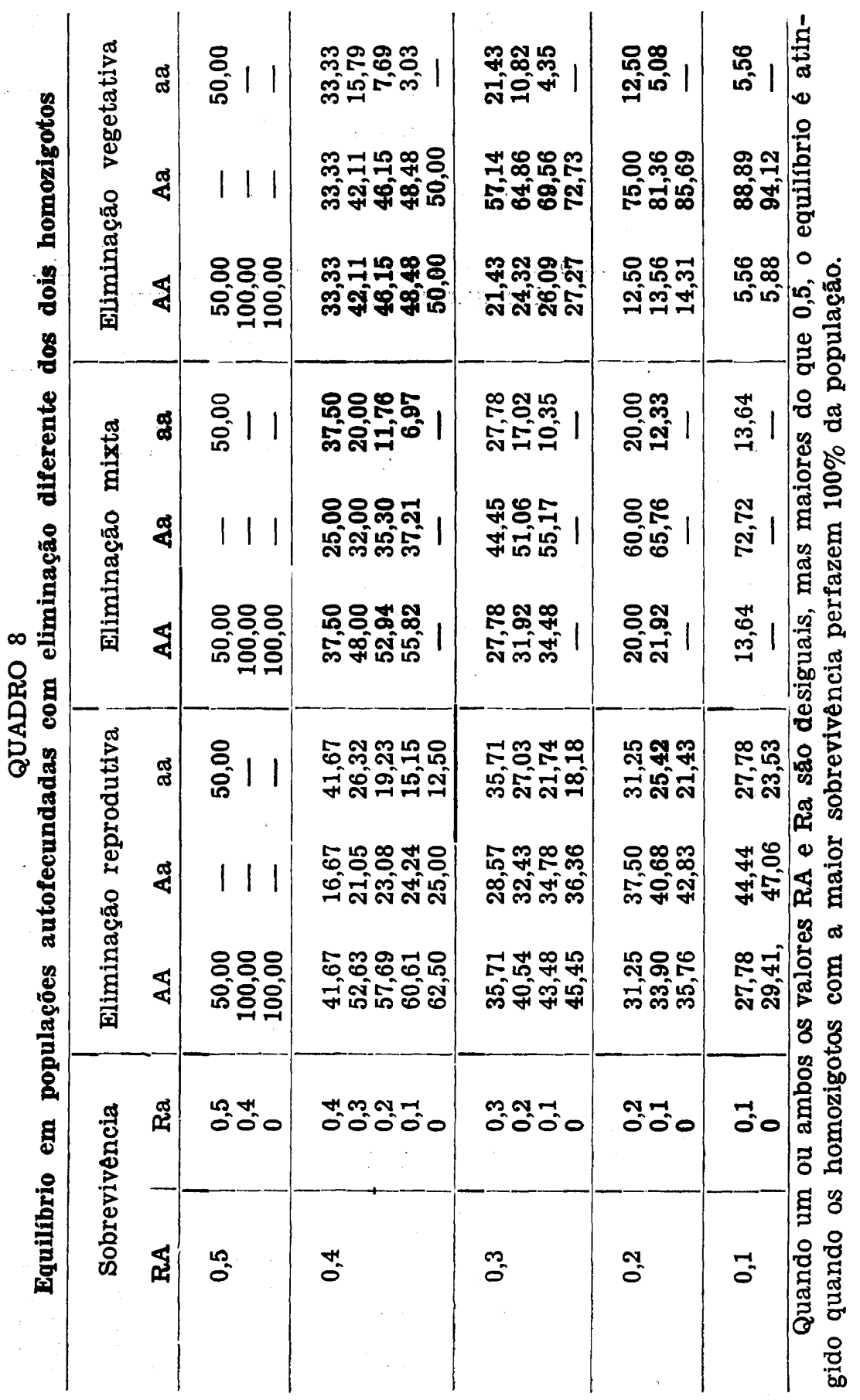


Resultado da eliminação diferencial dos dois homozigotos em populações com autofecundação

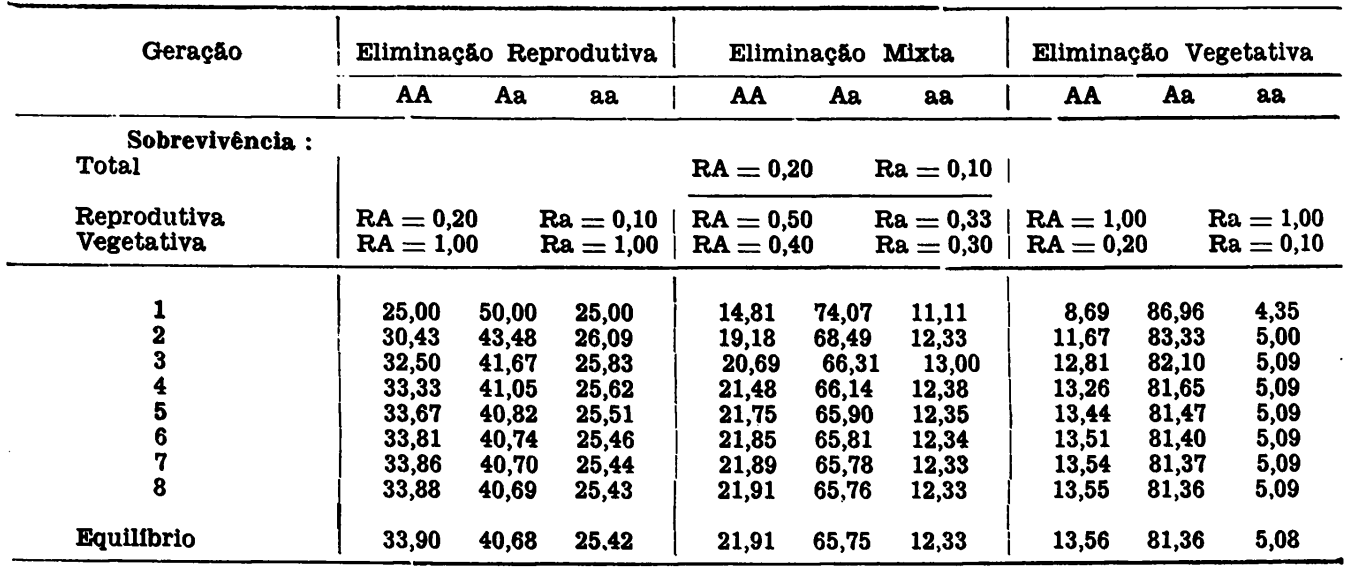

\begin{tabular}{|c|c|c|c|c|c|c|c|c|c|}
\hline \multirow{2}{*}{$\begin{array}{l}\text { Sobrevivéncia : } \\
\text { Total } \\
\text { Reprodutiva } \\
\text { Vegetativa }\end{array}$} & \multirow{2}{*}{\multicolumn{2}{|c|}{$\begin{array}{l}\mathrm{RA}=0,40 \\
\mathrm{RA}=1,00\end{array}$}} & \multirow[b]{2}{*}{$\begin{array}{l}\mathrm{Ra}=0,20 \\
\mathrm{Ra}=1,00\end{array}$} & \multicolumn{2}{|c|}{$\mathrm{RA}=0,40$} & $R a=0,20$ & \multirow[b]{2}{*}{$\begin{array}{l}\mathrm{RA}=1,00 \\
\mathrm{RA}=0,40\end{array}$} & \multirow{2}{*}{\multicolumn{2}{|c|}{$\begin{array}{l}\mathrm{Ra}=1,00 \\
\mathrm{Ra}=0,20\end{array}$}} \\
\hline & & & & $\begin{array}{l}\mathbf{R A}=\mathbf{0 , 6} \\
\mathbf{R A}=0,6\end{array}$ & & $\begin{array}{l}\mathrm{Ra}=0,50 \\
\mathrm{Ra}=0,40\end{array}$ & & & \\
\hline $\begin{array}{r}1 \\
2 \\
3 \\
4 \\
5 \\
6 \\
7 \\
8 \\
9 \\
10\end{array}$ & $\begin{array}{l}25,00 \\
34,62 \\
40,67 \\
44,89 \\
47,94 \\
50,20 \\
51,89 \\
53,17 \\
54,14 \\
54,90\end{array}$ & $\begin{array}{l}50,00 \\
38,46 \\
33,33 \\
30,41 \\
28,53 \\
27,21 \\
26,26 \\
25,55 \\
25,02 \\
24,60\end{array}$ & $\begin{array}{l}25,00 \\
26,92 \\
26,00 \\
24,70 \\
23,53 \\
22,59 \\
21,85 \\
21,28 \\
20,84 \\
20,50\end{array}$ & $\begin{array}{l}20,00 \\
29,67 \\
35,81 \\
40,07 \\
43,13 \\
45,39 \\
49,10 \\
48,36 \\
49,34 \\
50,11\end{array}$ & $\begin{array}{l}66,67 \\
54,95 \\
48,92 \\
45,24 \\
42,76 \\
41,00 \\
38,19 \\
38,74 \\
38,00 \\
37,42\end{array}$ & $\begin{array}{l}13,33 \\
15,38 \\
15,27 \\
14,69 \\
14,11 \\
13,61 \\
12,71 \\
12,90 \\
12,66 \\
12,47\end{array}$ & $\begin{array}{l}15,38 \\
24,00 \\
29,68 \\
33,68 \\
36,59 \\
38,75 \\
40,39 \\
41,64 \\
42,60 \\
43,35\end{array}$ & $\begin{array}{l}\mathbf{7 6 , 9 2} \\
66,67 \\
60,83 \\
57,05 \\
54,43 \\
52,53 \\
51,11 \\
50,03 \\
49,20 \\
48,57\end{array}$ & $\begin{array}{l}7,69 \\
9,33 \\
9,49 \\
9,27 \\
8,89 \\
8,72 \\
8,50 \\
8,33 \\
8,20 \\
8,09\end{array}$ \\
\hline Equilíbrio & 57,69 & 23,08 & 19,23 & 52,95 & 35,31 & 11,77 & 46,15 & 46,16 & 7,69 \\
\hline
\end{tabular}

\begin{tabular}{|c|c|c|c|c|c|c|c|c|c|}
\hline \multirow{2}{*}{$\begin{array}{l}\text { Sobrevivência : } \\
\text { Total } \\
\text { Reprodutiva } \\
\text { Vegetativa }\end{array}$} & & & & \multicolumn{2}{|c|}{$R A=0,60$} & $\mathrm{Ra}=0,40$ & \multirow{2}{*}{\multicolumn{2}{|c|}{$\begin{array}{l}\mathrm{RA}=1,00 \\
\mathrm{RA}=0,60\end{array}$}} & \multirow[b]{2}{*}{$\begin{array}{l}\mathrm{Ra}=1,00 \\
\mathrm{Ra}=0,40\end{array}$} \\
\hline & \multicolumn{2}{|c|}{$\begin{array}{l}\mathrm{RA}=0,60 \\
\mathrm{RA}=1,00\end{array}$} & $\begin{array}{l}\mathrm{Ra}=0,40 \\
\mathrm{Ra}=1,00\end{array}$ & \multicolumn{2}{|c|}{$\begin{array}{l}\mathrm{RA}=0,75 \\
\mathrm{RA}=0,80\end{array}$} & $\begin{array}{l}R a=0,67 \\
R a=0,60\end{array}$ & & & \\
\hline $\begin{array}{r}1 \\
2 \\
3 \\
4 \\
5 \\
6 \\
7 \\
8 \\
9 \\
10\end{array}$ & $\begin{array}{l}25,00 \\
33,67 \\
45,05 \\
52,02 \\
58,12 \\
63,58 \\
68,46 \\
72,81 \\
76,67 \\
80,05\end{array}$ & $\begin{array}{r}50,00 \\
33,33 \\
24,75 \\
19,38 \\
15,62 \\
12,80 \\
10,60 \\
8,83 \\
7,37 \\
6,17\end{array}$ & $\begin{array}{r}25,00 \\
30,00 \\
30,20 \\
28,60 \\
26,26 \\
23,62 \\
20,94 \\
18,36 \\
15,96 \\
13,78\end{array}$ & $\begin{array}{l}23,53 \\
36,36 \\
45,67 \\
53,24 \\
59,72 \\
65,35 \\
70,27 \\
74,59 \\
78,35 \\
81,62\end{array}$ & $\begin{array}{r}58,82 \\
41,32 \\
31,37 \\
24,80 \\
20,06 \\
16,45 \\
13,60 \\
11,30 \\
9,42 \\
7,86\end{array}$ & $\begin{array}{l}17,65 \\
22,31 \\
22,96 \\
21,96 \\
20,23 \\
18,20 \\
16,12 \\
12,11 \\
12,23 \\
10,52\end{array}$ & $\begin{array}{l}20,00 \\
32,68 \\
42,33 \\
50,31 \\
57,16 \\
63,16 \\
68,39 \\
72,98 \\
76,98 \\
80,45\end{array}$ & $\begin{array}{l}66,67 \\
49,50 \\
38,76 \\
31,24 \\
25,61 \\
21,20 \\
17,65 \\
14,75 \\
12,34 \\
10,33\end{array}$ & $\begin{array}{r}13,33 \\
17,82 \\
18,91 \\
18,45 \\
17,22 \\
15,64 \\
13,95 \\
12,27 \\
10,68 \\
9,22\end{array}$ \\
\hline Equilibrio & 100,00 & - & - & 100,00 & - & - & 100,00 & - & - \\
\hline $\begin{array}{l}\text { Sobrevivência : } \\
\text { Total }\end{array}$ & & & & $\mathbf{R A}=\mathbf{0}$, & & $\mathrm{Ra}=0,60$ & & & \\
\hline $\begin{array}{l}\text { Reprodutiva } \\
\text { Vegetativa }\end{array}$ & $\begin{array}{l}\mathbf{R A}=0,8 \\
\mathbf{R A}=\mathbf{1}, \mathbf{C}\end{array}$ & & $\begin{array}{l}\mathrm{Ra}=0,60 \\
\mathbf{R a}=\mathbf{1 , 0 0}\end{array}$ & $\begin{array}{l}\mathrm{RA}=0, \\
\mathrm{RA}=0,\end{array}$ & & $\begin{array}{l}R_{a}=0,75 \\
R_{a}=0,80\end{array}$ & $\begin{array}{l}\mathbf{R A}= \\
\mathbf{R A}=\end{array}$ & & $\begin{array}{l}\mathbf{R} \mathbf{a}=1,00 \\
\mathbf{R} \mathbf{a}=0,60\end{array}$ \\
\hline $\begin{array}{r}1 \\
2 \\
3 \\
4 \\
5 \\
6 \\
7 \\
8 \\
9 \\
9 \\
10\end{array}$ & $\begin{array}{l}25,00 \\
38,24 \\
18,52 \\
55,68 \\
62,61 \\
68,79 \\
74,28 \\
79,08 \\
83,20 \\
86,66\end{array}$ & $\begin{array}{r}50,00 \\
29,41 \\
47,78 \\
12,03 \\
7,92 \\
5,23 \\
3,45 \\
2,26 \\
1,40 \\
0,95\end{array}$ & $\begin{array}{l}25,00 \\
32,35 \\
33,70 \\
32,29 \\
29,47 \\
25,98 \\
22,27 \\
18,66 \\
15,31 \\
12,38\end{array}$ & $\begin{array}{l}24,32 \\
38,36 \\
48,60 \\
56,96 \\
64,15 \\
70,41 \\
77,86 \\
80,54 \\
84,50 \\
87,77\end{array}$ & $\begin{array}{r}\mathbf{5 4 , 0 5} \\
\mathbf{3 2 , 8 7} \\
20,93 \\
13,68 \\
9,02 \\
\mathbf{5 , 9 5} \\
\mathbf{3}, 91 \\
\mathbf{2 , 5 6} \\
\mathbf{1 , 6 6} \\
\mathbf{1 , 0 7}\end{array}$ & $\begin{array}{l}21,62 \\
28,85 \\
30,47 \\
29,36 \\
26,84 \\
23,64 \\
20,22 \\
16,90 \\
13,84 \\
11,15\end{array}$ & $\begin{array}{l}23,53 \\
38,52 \\
49,66 \\
58,65 \\
66,17 \\
72,55 \\
77,95 \\
82,46 \\
86,18 \\
89,21\end{array}$ & $\begin{array}{r}58,82 \\
37,04 \\
24,06 \\
15,84 \\
10,46 \\
6,90 \\
4,52 \\
2,95 \\
1,81 \\
1,23\end{array}$ & $\begin{array}{r}17,64 \\
24,44 \\
26,28 \\
25,51 \\
23,36 \\
20,55 \\
17,52 \\
14,59 \\
11,91 \\
9,56\end{array}$ \\
\hline Equilíbrio & 100,00 & - & - & 100,00 & - & - & 100,00 & - & - \\
\hline
\end{tabular}


QUADRO 10

Efeito da eliminação de um dos homózigotos em populações com autofecundação

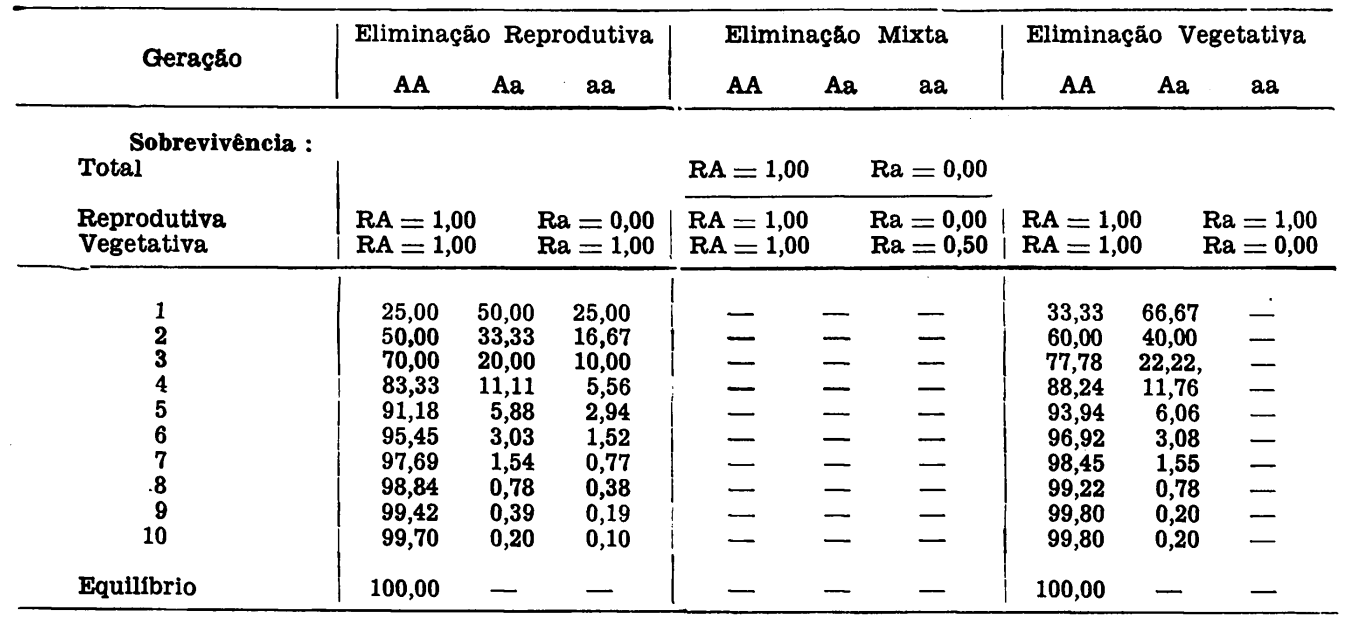

\begin{tabular}{|c|c|c|c|c|c|c|c|c|c|}
\hline \multirow{2}{*}{$\begin{array}{l}\text { Sobrevivência : } \\
\text { Total } \\
\text { Reprodutiva } \\
\text { Vegetativa }\end{array}$} & \multicolumn{3}{|c|}{1} & \multicolumn{2}{|c|}{$\mathbf{R A}=1,00$} & $\mathrm{Ra}=0,20$ & \multirow{2}{*}{\multicolumn{2}{|c|}{$\begin{array}{l}\mathrm{RA}=1,00 \\
\mathrm{RA}=1,00\end{array}$}} & \multirow[b]{2}{*}{$\begin{array}{l}a=1,00 \\
a=0,20\end{array}$} \\
\hline & \multicolumn{2}{|c|}{$\begin{array}{l}\mathrm{RA}=1,00 \\
\mathrm{RA}=1,00\end{array}$} & $\begin{array}{l}\mathbf{R a}=0,20 \\
\mathbf{R a}=\mathbf{1 , 0 0}\end{array}$ & \multicolumn{2}{|c|}{$\begin{array}{l}\mathbf{R A}=1,00 \\
\mathbf{R A}=1,00\end{array}$} & $\begin{array}{l}\mathrm{Ra}=0,50 \\
\mathrm{Ra}=0,40\end{array}$ & & & \\
\hline $\begin{array}{r}1 \\
2 \\
3 \\
4 \\
5 \\
6 \\
7 \\
8 \\
9 \\
10\end{array}$ & $\begin{array}{l}25,00 \\
46,88 \\
66,29 \\
80,54 \\
89,47 \\
94,51 \\
97,20 \\
98,58 \\
99,29 \\
99,63\end{array}$ & $\begin{array}{r}50,00 \\
31,25 \\
18,94 \\
10,74 \\
5,77 \\
3,00 \\
1,53 \\
0,77 \\
0,39 \\
0,20\end{array}$ & $\begin{array}{r}25,00 \\
21,88 \\
14,77 \\
8,72 \\
4,76 \\
2,49 \\
1,27 \\
0,65 \\
0,32 \\
0,17\end{array}$ & $\begin{array}{l}29,41 \\
53,96 \\
72,73 \\
84,99 \\
92,10 \\
95,94 \\
97,94 \\
98,97 \\
99,48 \\
99,74\end{array}$ & $\begin{array}{r}58,82 \\
35,97 \\
20,78 \\
11,33 \\
5,94 \\
3,05 \\
1,54 \\
0,78 \\
0,39 \\
0,20\end{array}$ & $\begin{array}{r}11,77 \\
10,07 \\
6,48 \\
3,68 \\
1,96 \\
1,01 \\
0,52 \\
0,25 \\
0,13 \\
0,06\end{array}$ & $\begin{array}{l}31,25 \\
56,82 \\
75,17 \\
86,58 \\
93,01 \\
96,43 \\
98,20 \\
99,09 \\
99,55 \\
99,77\end{array}$ & $\begin{array}{r}62,50 \\
37,88 \\
21,48 \\
11,54 \\
6,00 \\
3,06 \\
1,55 \\
0,78 \\
0,40 \\
0,20\end{array}$ & $\begin{array}{l}6,25 \\
5,30 \\
3,35 \\
1,88 \\
0,99 \\
0,51 \\
0,25 \\
0,13 \\
0,06 \\
0,03\end{array}$ \\
\hline Equilíbrio & 100,00 & - & - & 100,00 & - & - & 100,00 & - & - \\
\hline
\end{tabular}

\begin{tabular}{|c|c|c|c|c|c|c|c|c|c|}
\hline \multirow{2}{*}{$\begin{array}{l}\text { Sobrevivência : } \\
\text { Total } \\
\text { Reprodutiva } \\
\text { Vegetativa }\end{array}$} & \multirow{2}{*}{\multicolumn{2}{|c|}{$\begin{array}{l}\mathrm{RA}=1,00 \\
\mathrm{RA}=1,00\end{array}$}} & \multirow[b]{2}{*}{$\begin{array}{l}\mathrm{Ra}=0,50 \\
\mathrm{Ra}=1,00\end{array}$} & \multicolumn{2}{|c|}{$\mathbf{R A}=1,00$} & $\mathbf{R a}=0,50$ & \multirow{2}{*}{\multicolumn{2}{|c|}{$\begin{array}{l}\mathrm{RA}=1,00 \\
\mathrm{RA}=1,00\end{array}$}} & \multirow[b]{2}{*}{$\begin{array}{l}\mathbf{R a}=1,00 \\
\mathbf{R a}=\mathbf{0 , 5 0}\end{array}$} \\
\hline & & & & $\begin{array}{l}\mathbf{R A}=1 \\
\mathbf{R A}=1\end{array}$ & & $\begin{array}{l}\mathrm{Ra}=1,00 \\
\mathrm{Ra}=0,70\end{array}$ & & & \\
\hline $\begin{array}{r}1 \\
2 \\
3 \\
4 \\
5 \\
6 \\
7 \\
8 \\
9 \\
10\end{array}$ & $\begin{array}{l}25,00 \\
42,86 \\
58,33 \\
71,43 \\
81,57 \\
88,73 \\
93,38 \\
96,23 \\
97,89 \\
98,83\end{array}$ & $\begin{array}{r}50,00 \\
28,57 \\
16,67 \\
9,52 \\
5,26 \\
2,82 \\
1,47 \\
0,75 \\
0,38 \\
0,20\end{array}$ & $\begin{array}{r}25,00 \\
28,57 \\
25,00 \\
19,05 \\
13,16 \\
8,45 \\
5,15 \\
3,02 \\
1,72 \\
0,97\end{array}$ & $\begin{array}{l}27,03 \\
46,88 \\
63,06 \\
75,76 \\
84,93 \\
91,04 \\
94,85 \\
97,11 \\
98,40 \\
99,12\end{array}$ & $\begin{array}{r}54,05 \\
31,25 \\
18,02 \\
10,10 \\
5,48 \\
2,89 \\
1,49 \\
0,76 \\
0,39 \\
0,20\end{array}$ & $\begin{array}{r}18,92 \\
21,87 \\
18,92 \\
14,14 \\
9,59 \\
6,07 \\
3,66 \\
2,13 \\
1,21 \\
0,68\end{array}$ & $\begin{array}{l}28,57 \\
50,00 \\
66,67 \\
78,95 \\
87,32 \\
92,65 \\
95,85 \\
97,70 \\
98,74 \\
99,31\end{array}$ & $\begin{array}{r}\mathbf{5 7 , 1 4} \\
33,33 \\
19,05 \\
10,53 \\
5,63 \\
2,94 \\
1,51 \\
0,77 \\
0,39 \\
0,20\end{array}$ & $\begin{array}{r}14,29 \\
16,67 \\
14,28 \\
10,53 \\
7,05 \\
4,41 \\
2,64 \\
1,53 \\
0,87 \\
0,49\end{array}$ \\
\hline Equilíbrio & 100,00 & - & - & 100,00 & - & - & 100,00 & - & - \\
\hline
\end{tabular}

\begin{tabular}{|c|c|c|c|c|c|c|c|c|c|}
\hline \multirow{2}{*}{$\begin{array}{l}\text { Sobrevivência : } \\
\text { Total } \\
\text { Reprodutiva } \\
\text { Vegetativa } \\
\end{array}$} & \multirow{2}{*}{\multicolumn{2}{|c|}{$\begin{array}{l}\mathbf{R A}=1,00 \\
\mathbf{R A}=1,00\end{array}$}} & \multirow[b]{2}{*}{$\begin{array}{l}\mathrm{Ra}=0,80 \\
\mathrm{Ra}=1,00\end{array}$} & \multicolumn{2}{|c|}{$\mathbf{R A}=1,00$} & $\mathbf{R a}=0,80$ & \multirow{2}{*}{\multicolumn{2}{|c|}{$\begin{array}{l}\mathbf{R A}=1,00 \\
\mathbf{R A}=1,00\end{array}$}} & \multirow[b]{2}{*}{$\begin{array}{l}\mathbf{R a}=1,00 \\
\mathbf{R a}=0,80\end{array}$} \\
\hline & & & & $\begin{array}{l}\mathbf{R A}=1 \\
\mathbf{R A}=1\end{array}$ & & $\begin{array}{l}\mathrm{Ra}=0,89 \\
\mathrm{Ra}=0,90\end{array}$ & & & \\
\hline $\begin{array}{r}1 \\
2 \\
3 \\
4 \\
5 \\
6 \\
7 \\
8 \\
9 \\
10\end{array}$ & $\begin{array}{l}25,00 \\
39,47 \\
49,44 \\
57,13 \\
63,51 \\
69,01 \\
73,81 \\
78,00 \\
81,65 \\
84,66\end{array}$ & $\begin{array}{r}50,00 \\
26,32 \\
14,12 \\
7,62 \\
4,10 \\
2,19 \\
1,16 \\
0,61 \\
0,32 \\
0,17\end{array}$ & $\begin{array}{l}25,00 \\
34,21 \\
36,44 \\
35,25 \\
32,39 \\
28,80 \\
25,03 \\
21,39 \\
18,03 \\
15,17\end{array}$ & $\begin{array}{l}25,64 \\
40,87 \\
51,30 \\
59,22 \\
65,64 \\
71,05 \\
75,70 \\
79,71 \\
83,15 \\
85,96\end{array}$ & $\begin{array}{r}51,28 \\
27,25 \\
14,66 \\
7,90 \\
4,23 \\
2,26 \\
1,19 \\
0,63 \\
0,33 \\
0,17\end{array}$ & $\begin{array}{l}23,08 \\
31,88 \\
34,04 \\
32,88 \\
30,13 \\
26,69 \\
23,11 \\
19,66 \\
16,52 \\
13,87\end{array}$ & $\begin{array}{l}26,32 \\
42,37 \\
53,32 \\
61,46 \\
67,91 \\
73,22 \\
77,70 \\
81,49 \\
84,70 \\
87,31\end{array}$ & $\begin{array}{r}52,63 \\
28,25 \\
15,23 \\
8,20 \\
4,38 \\
2,32 \\
1,22 \\
0,64 \\
0,33 \\
0,17\end{array}$ & $\begin{array}{l}21,05 \\
29,38 \\
31,45 \\
30,34 \\
27,71 \\
24,46 \\
21,08 \\
17,87 \\
14,97 \\
12,52\end{array}$ \\
\hline Equilíbrio & 100,00 & - & - & 100,00 & - & - & 100,00 & - & - \\
\hline
\end{tabular}




\section{QUADRO 11}

\begin{tabular}{|c|c|c|c|c|c|c|}
\hline \multirow[b]{2}{*}{$\begin{array}{l}\text { Frequên- } \\
\text { cla final } \\
\text { qm. }\end{array}$} & \multicolumn{6}{|c|}{ Frequencias iniciais: } \\
\hline & $\underset{\text { Cruza- }}{q}=$ & $\begin{array}{l}0,8 \\
\text { auto } \\
\text { fecund. }\end{array}$ & $\begin{array}{c}q= \\
\text { Cruza- } \\
\text { mentos }\end{array}$ & $\begin{array}{l}=\mathbf{0 , 5} \\
\mid \text { auto } \\
\text { fecund. }\end{array}$ & $\begin{array}{c}q= \\
\text { Cruss- } \\
\text { mentos }\end{array}$ & $\begin{array}{l}0,1 \\
\text { | auto } \\
\text { fecund. }\end{array}$ \\
\hline & \multicolumn{6}{|c|}{ Número de geraçoes: } \\
\hline 0,10 & 9 & 7 & 8 & 3 & - & - \\
\hline 0,05 & 19 & 8 & 18 & 4 & 10 & 1 \\
\hline 0,01 & 99 & 10 & 88 & 7 & 90 & 4 \\
\hline 0,001 & 198 & 14 & 198 & 10 & 190 & 7 \\
\hline
\end{tabular}

QUADRO 12

\begin{tabular}{|c|c|c|c|c|}
\hline $\begin{array}{l}\text { Pares de } \\
\text { fatores }\end{array}$ & $\begin{array}{c}\text { 3a. } \\
\text { Ceraçăo }\end{array}$ & $\begin{array}{c}\text { 4a. } \\
\text { Geraçă }\end{array}$ & $\begin{array}{c}5.2 \\
\text { Geraça }\end{array}$ & $\begin{array}{c}6.8 \\
\text { Ceragko }\end{array}$ \\
\hline $\begin{array}{r}5 \\
10 \\
20 \\
30\end{array}$ & $\begin{array}{c}\text { Porc } \\
\\
51,3 \\
26,3 \\
6,9 \\
1,8\end{array}$ & $\begin{array}{c}\text { agem de } \\
\begin{array}{l}72,4 \\
52,4 \\
27,6 \\
14,4\end{array}\end{array}$ & \begin{tabular}{|c|} 
omozigotas \\
$\mathbf{8 5 , 3}$ \\
$\mathbf{7 2 , 8}$ \\
$\mathbf{5 3 , 0}$ \\
$\mathbf{3 8 , 6}$
\end{tabular} & $\begin{array}{c}\text { completas } \\
92,4 \\
85,4 \\
73,0 \\
62,3\end{array}$ \\
\hline
\end{tabular}


QUADRO 13

\begin{tabular}{|c|c|c|c|c|c|c|}
\hline \multirow{2}{*}{ 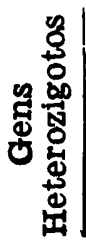 } & \multicolumn{2}{|c|}{ 2a. Geraçåo } & \multicolumn{2}{|c|}{ 3a. Geraçåo } & \multicolumn{2}{|c|}{ 6a. Geração } \\
\hline & $\begin{array}{l}\text { Freq. \% } \\
\text { simples }\end{array}$ & $\begin{array}{l}\text { Freq. \% } \\
\text { acumul. }\end{array}$ & $\begin{array}{l}\text { Freq. \% } \\
\text { simples }\end{array}$ & $\begin{array}{l}\text { Freq. \% } \\
\text { acumul. }\end{array}$ & $\begin{array}{l}\text { Freq. \% } \\
\text { simples }\end{array}$ & $\begin{array}{l}\text { Freq\% } \\
\text { acumul }\end{array}$ \\
\hline
\end{tabular}

30 pares de fatores mendelianas

\begin{tabular}{r|r|r|r|r|r|r}
0 & - & - & 1,8 & 1,8 & 62,3 & 62,3 \\
1 & 0,2 & 0,2 & 7,8 & 9,6 & 29,7 & 92,0 \\
2 & 0,9 & 1,1 & 16,2 & 25,8 & 6,8 & 98,8 \\
3 & 2,7 & 3,8 & 21,6 & 47,4 & - & $=$ \\
4 & 6,0 & 9,8 & 20,8 & 68,2 & - & $=$ \\
5 & 10,5 & 20,3 & 15,4 & 83,6 & - & $=$ \\
6 & 14,6 & 34,9 & 9,2 & 92,8 & - & $=$ \\
7 & 16,6 & 51,5 & 4,5 & 97,3 & - & $=$ \\
8 & 15,9 & 67,4 & - & - & - & $=$ \\
9 & 13,0 & 80,4 & - & - & - & $=$ \\
10 & 9,1 & 89,5 & - & - & - & $=$ \\
11 & 5,5 & 95,0 & - & - & - & $=$ \\
12 & 2,9 & 97,9 & - & - & - & - \\
\hline
\end{tabular}

20 pares de fatores mendelianos

\begin{tabular}{l|r|r|r|r|r|r}
0 & 0,3 & 0,3 & $\mathbf{6 , 9}$ & $\mathbf{6 , 9}$ & $\mathbf{7 3 , 0}$ & $\mathbf{7 3 , 0}$ \\
1 & 2,1 & 2,4 & 19,5 & $\mathbf{2 6 , 4}$ & $\mathbf{2 3 , 2}$ & $\mathbf{9 6 , 2}$ \\
$\mathbf{2}$ & $\mathbf{6 , 7}$ & 9,1 & 26,8 & $\mathbf{5 3 , 2}$ & $\mathbf{3 , 5}$ & $\mathbf{9 9 , 7}$ \\
3 & 13,4 & 22,5 & 23,0 & $\mathbf{7 6 , 2}$ & - & - \\
$\mathbf{4}$ & 19,0 & 41,5 & 14,0 & $\mathbf{9 0 , 2}$ & - & - \\
5 & 20,2 & $\mathbf{6 1 , 7}$ & $\mathbf{6 , 4}$ & $\mathbf{9 6 , 6}$ & - & - \\
$\mathbf{6}$ & 16,9 & $\mathbf{7 8 , 6}$ & - & - & - & - \\
$\mathbf{7}$ & 11,2 & $\mathbf{8 9 , 8}$ & - & - & - & - \\
$\mathbf{8}$ & $\mathbf{6 , 1}$ & $\mathbf{9 5 , 9}$ & - & - & - & - \\
\hline
\end{tabular}

10 pares de fatores mendelianas

\begin{tabular}{l|r|r|r|r|r|r}
0 & $\mathbf{5 , 6}$ & $\mathbf{5 , 6}$ & 26,3 & $\mathbf{2 6 , 3}$ & $\mathbf{8 5 , 4}$ & $\mathbf{8 5 , 4}$ \\
$\mathbf{1}$ & 18,8 & 24,4 & 37,6 & 63,9 & 13,6 & 99,0 \\
$\mathbf{2}$ & 28,2 & $\mathbf{5 2 , 6}$ & 23,1 & $\mathbf{8 7 , 0}$ & - & - \\
3 & 25,0 & $\mathbf{7 7 , 6}$ & $\mathbf{9 , 3}$ & $\mathbf{9 6 , 3}$ & - & - \\
$\mathbf{4}$ & $\mathbf{1 4 , 6}$ & $\mathbf{9 2 , 2}$ & - & - & - & - \\
$\mathbf{5}$ & $\mathbf{5 , 8}$ & $\mathbf{9 8 , 0}$ & - & - & - & - \\
\hline
\end{tabular}

5 pares de fatores mendelianas

\begin{tabular}{l|r|r|r|r|r|r}
0 & 23,7 & 23,7 & 51,3 & 51,3 & 92,4 & 92,4 \\
1 & 39,6 & 63,3 & 36,6 & 87,9 & $\mathbf{7 , 3}$ & 99,7 \\
$\mathbf{2}$ & $\mathbf{2 6 , 4}$ & $\mathbf{8 9 , 7}$ & 10,5 & $\mathbf{9 8 , 4}$ & - & - \\
3 & $\mathbf{8 , 8}$ & $\mathbf{9 8 , 5}$ & - & - & - & - \\
\hline
\end{tabular}


Eliminaçäo diferencial dos dois homozigotos Populoçốes com reprodução cruzada

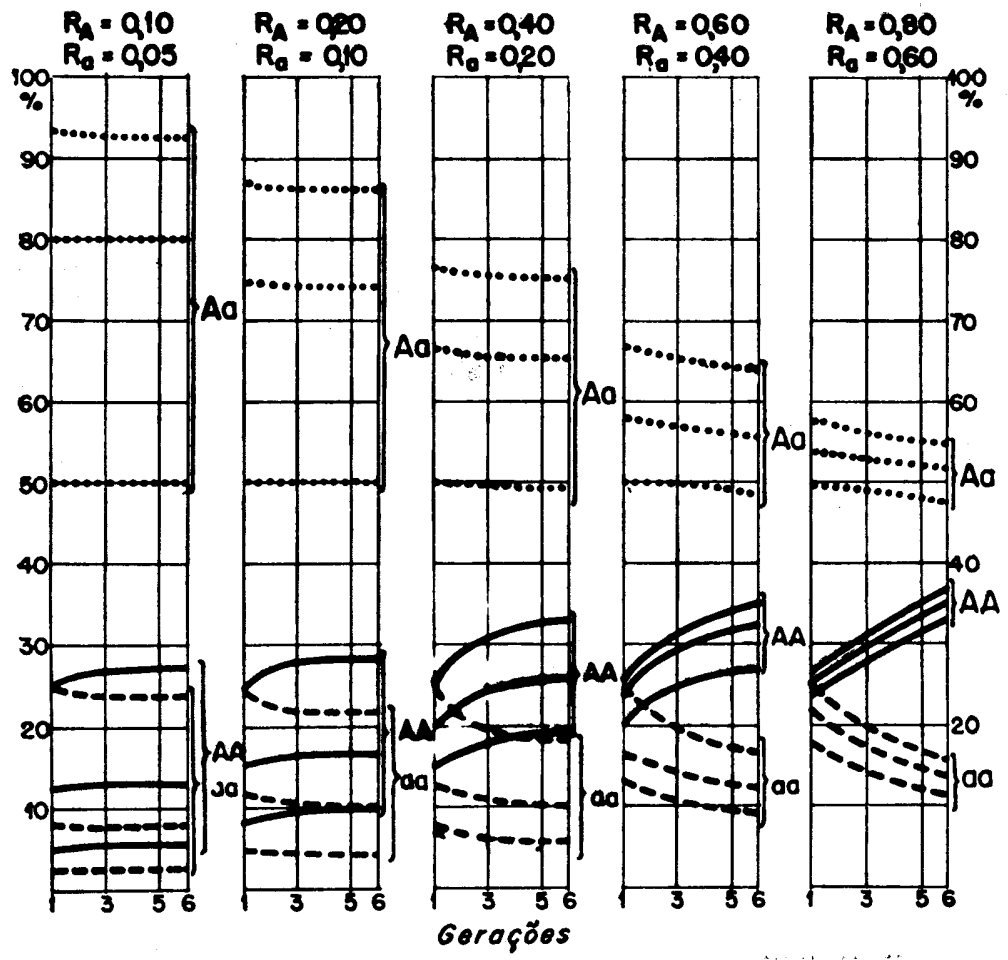

Figura 1 
है
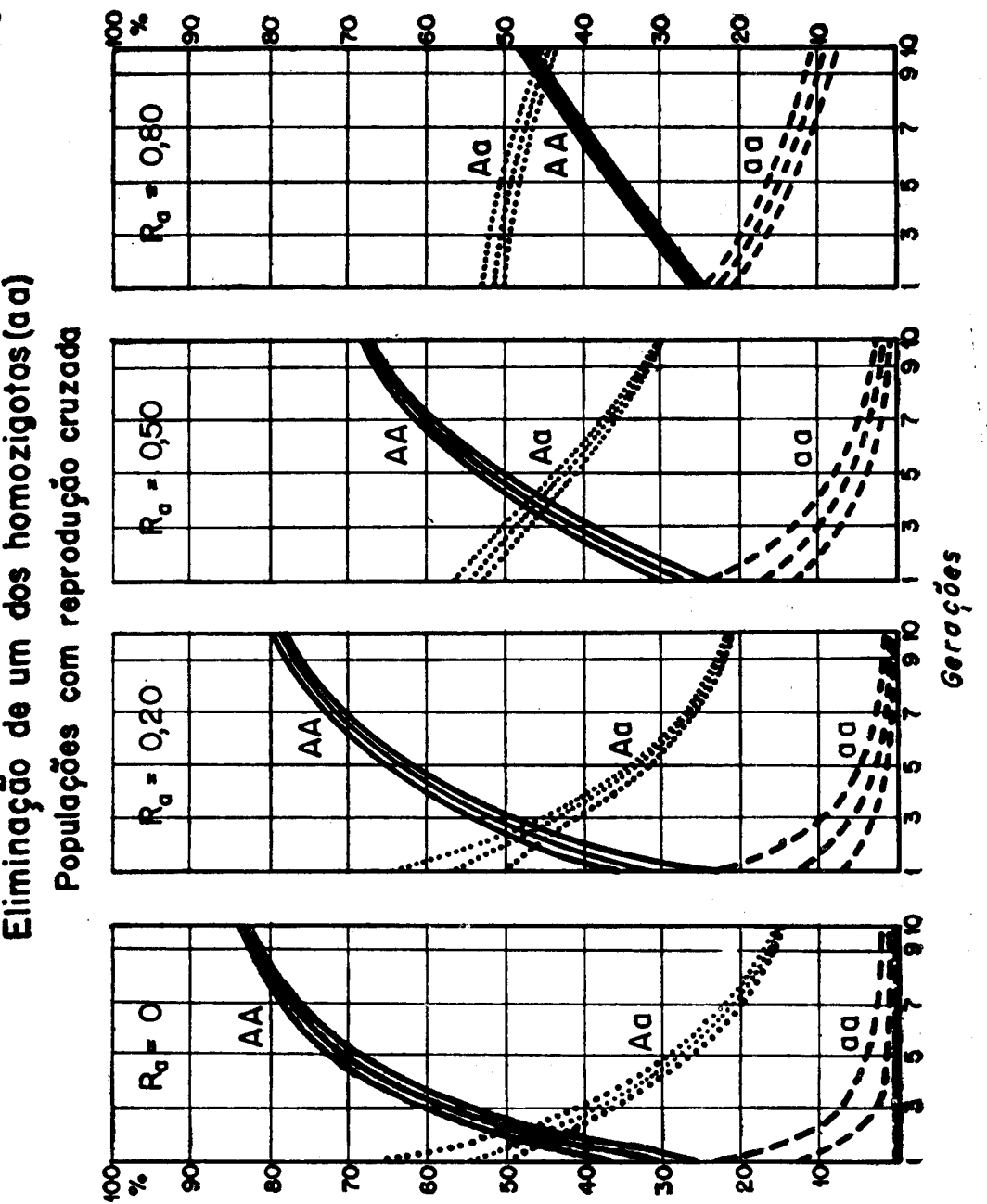
fig. 2

Eliminaçäo dos heterozigotos a um dos homozigotos

$$
\begin{array}{ll}
R_{A}=2,50 & R_{A}=1,25 \\
R_{a}=2,50 & R_{a}=0,75
\end{array}
$$

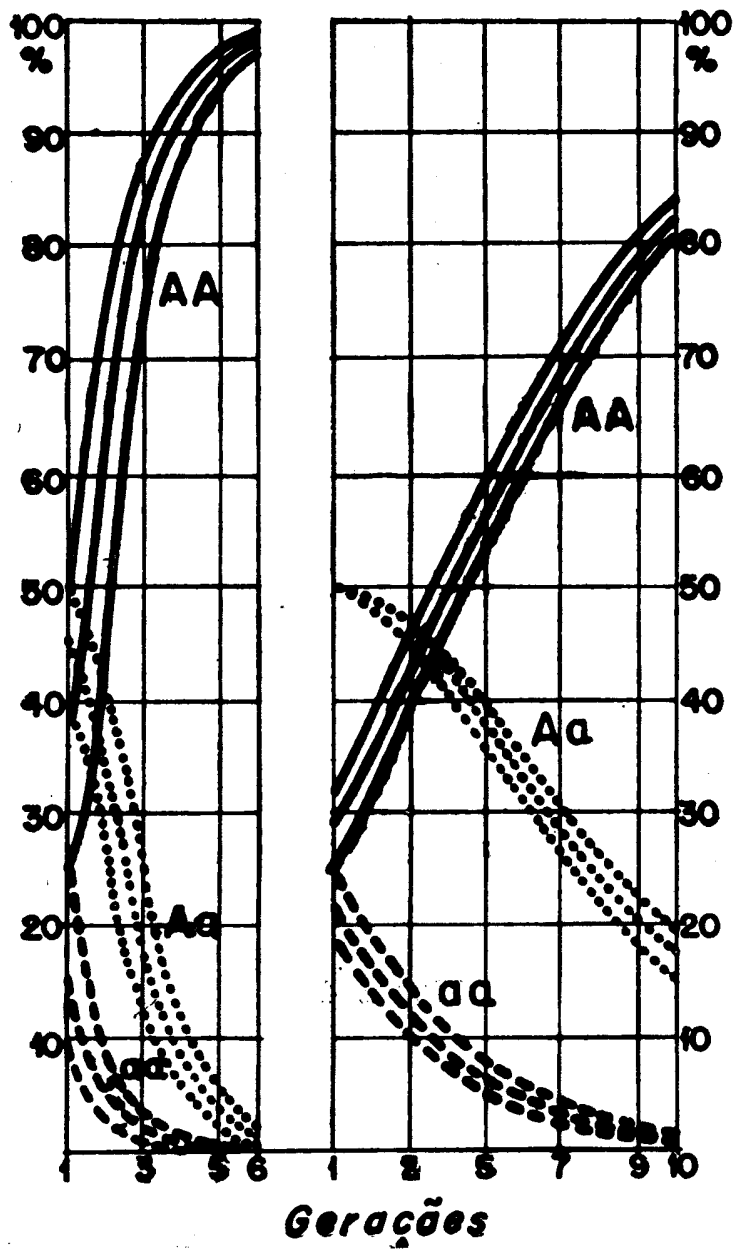

Figura 3 
Elíminação diferencial dos dọis sexos

Populaçōes com reproduçăo cruzada
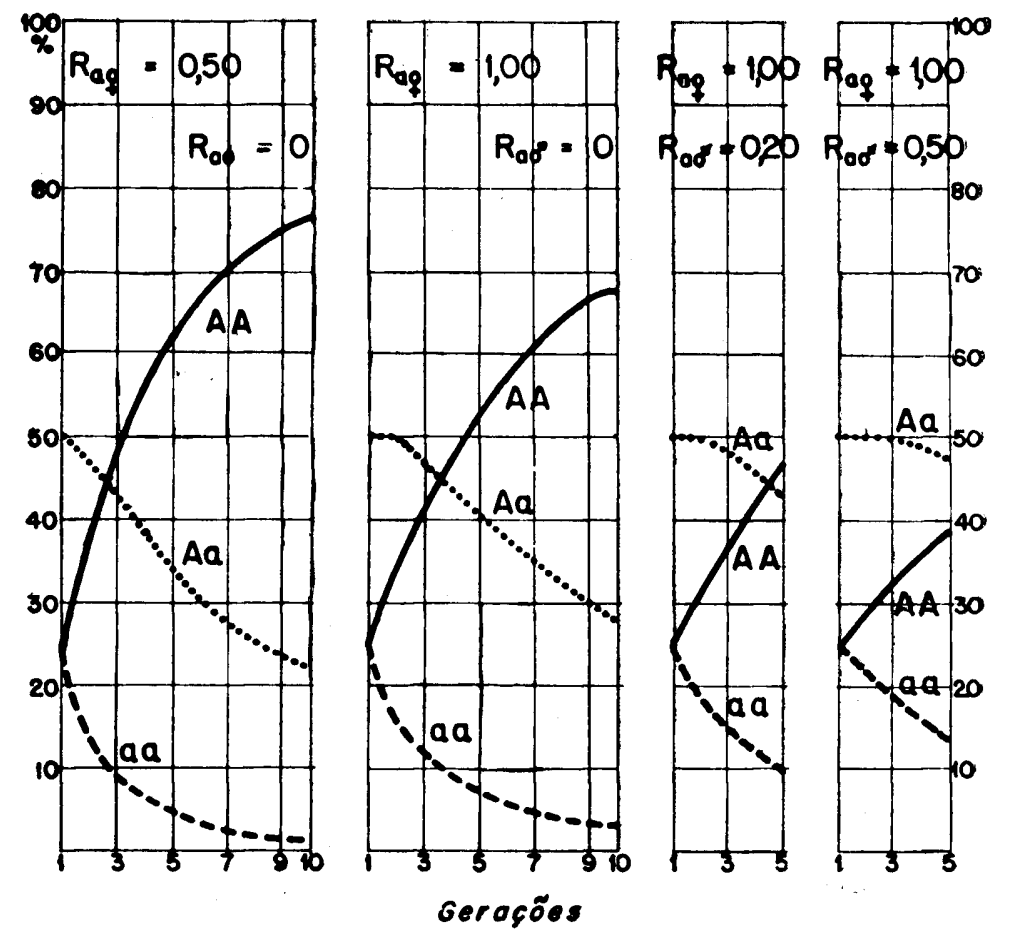

Figura 4 
Ellminoçäo gonofașica em um dos sexos

Populagäo com reproduçäo cruzado
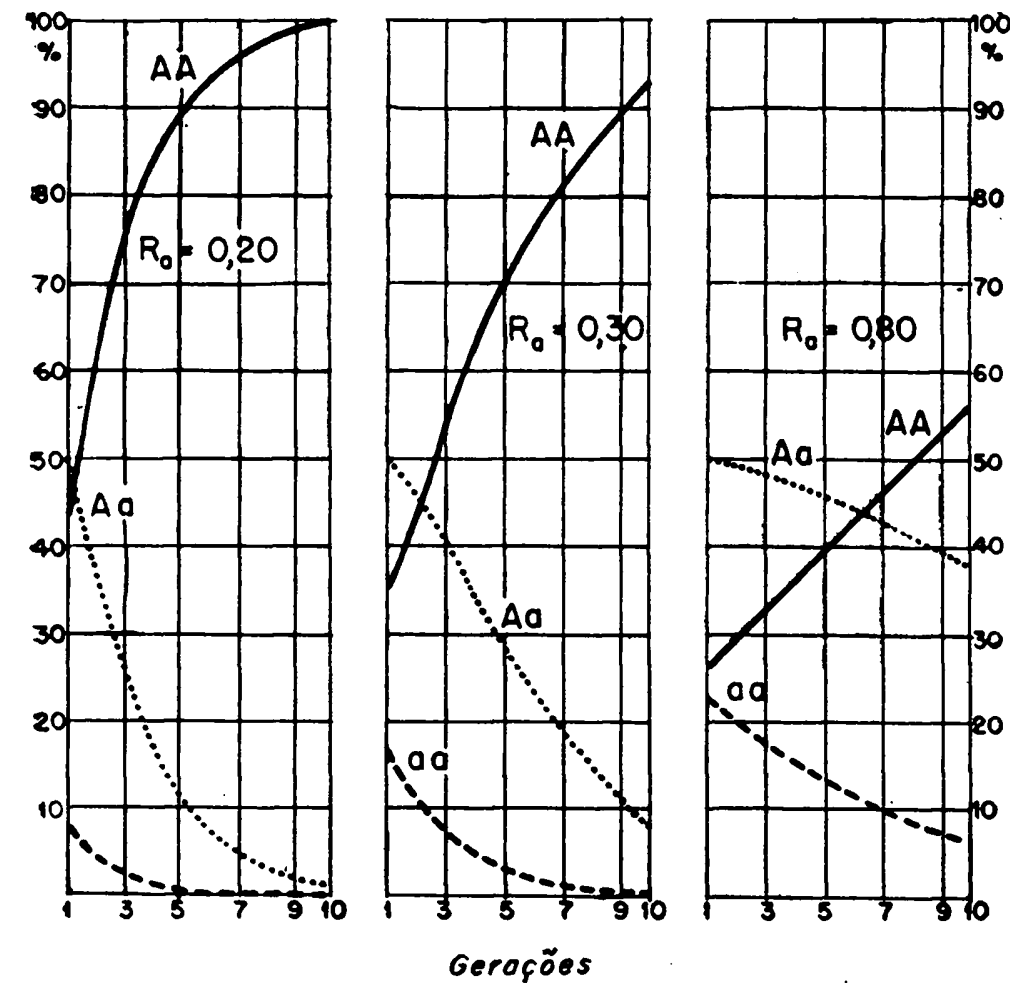

FHgura 5 
Eliminação gonofasica em ambos os sexos Populaçăo com reprodução cruzada
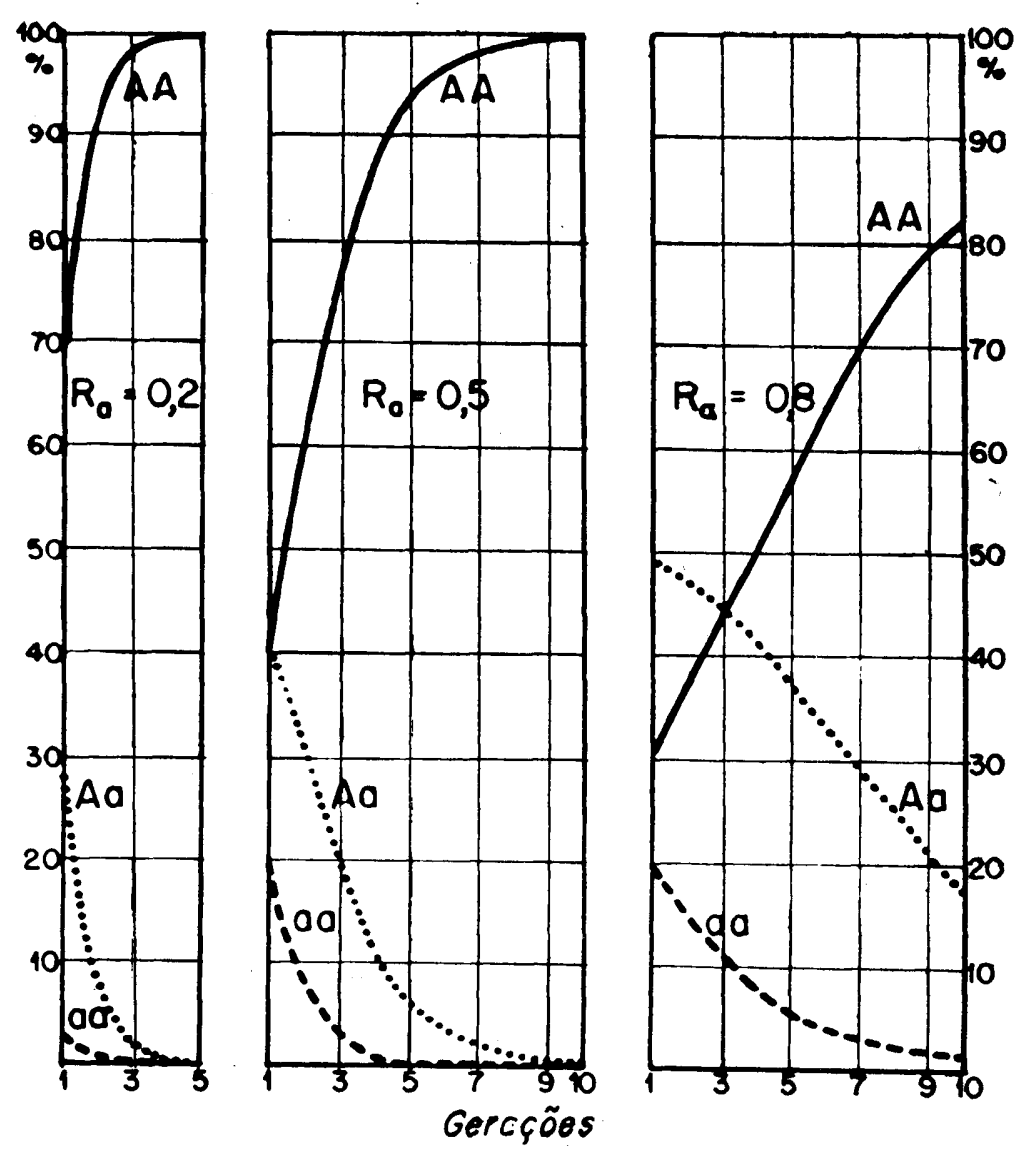

Figura 6 
3

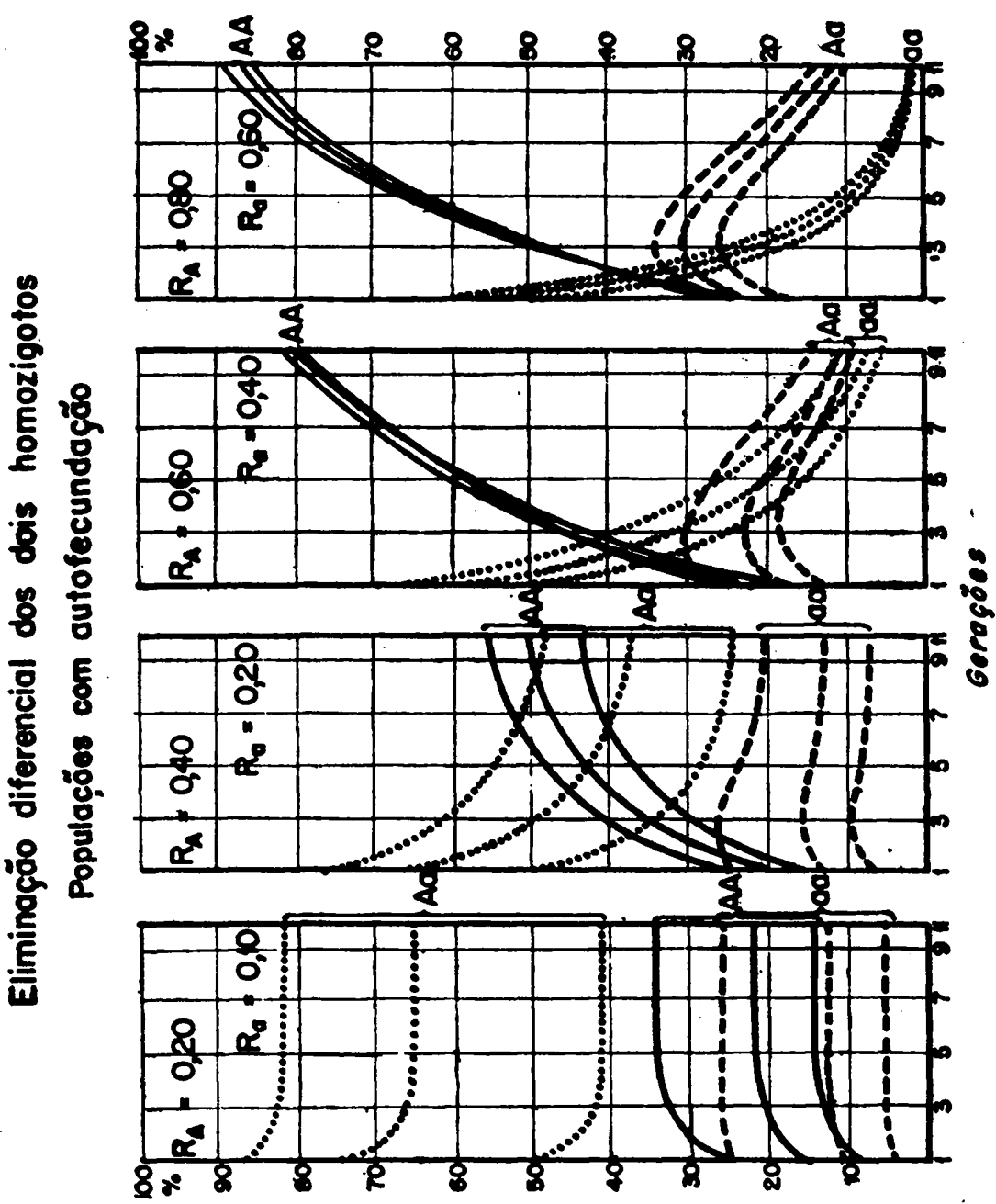


$\stackrel{-}{=}$

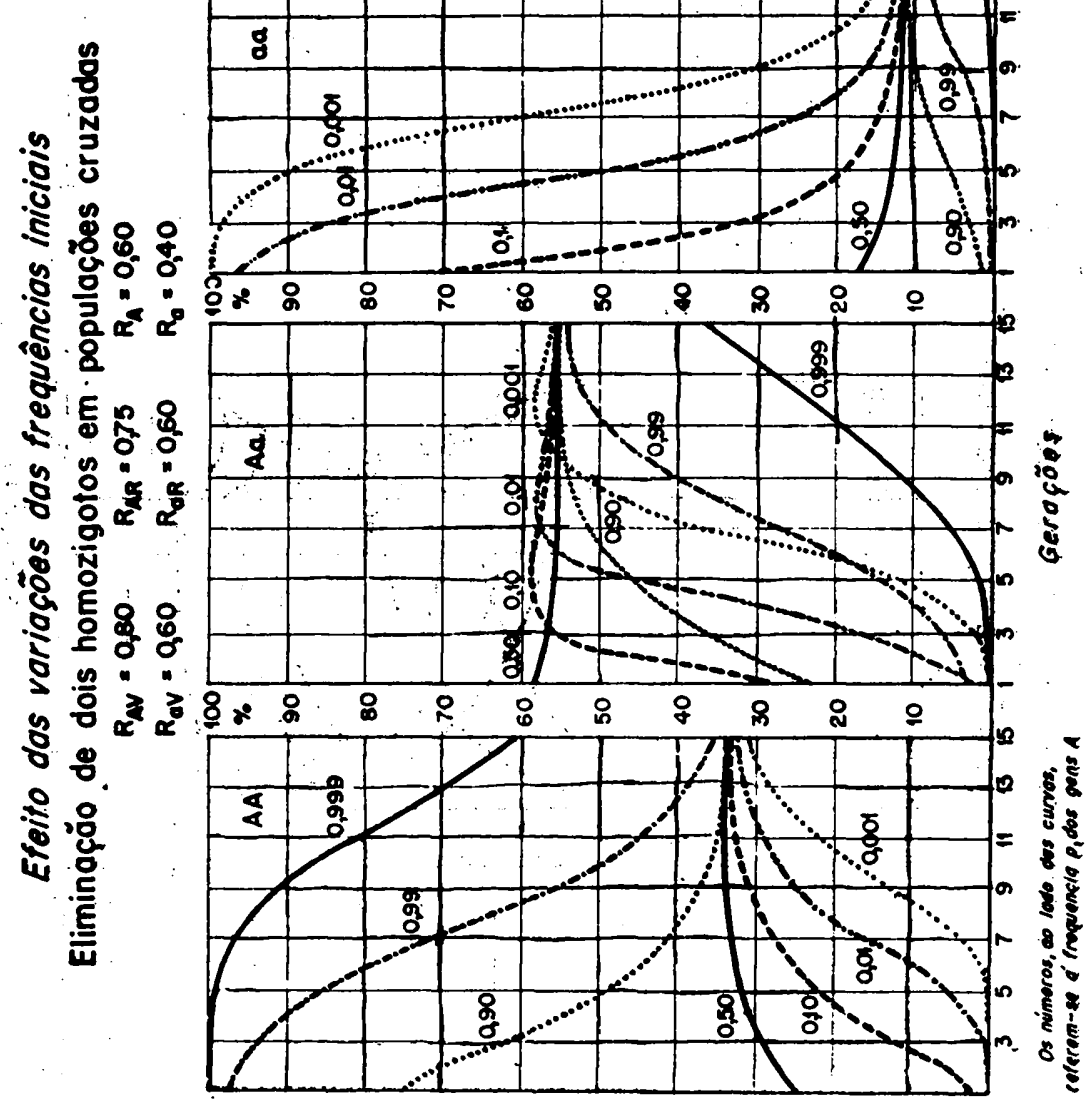




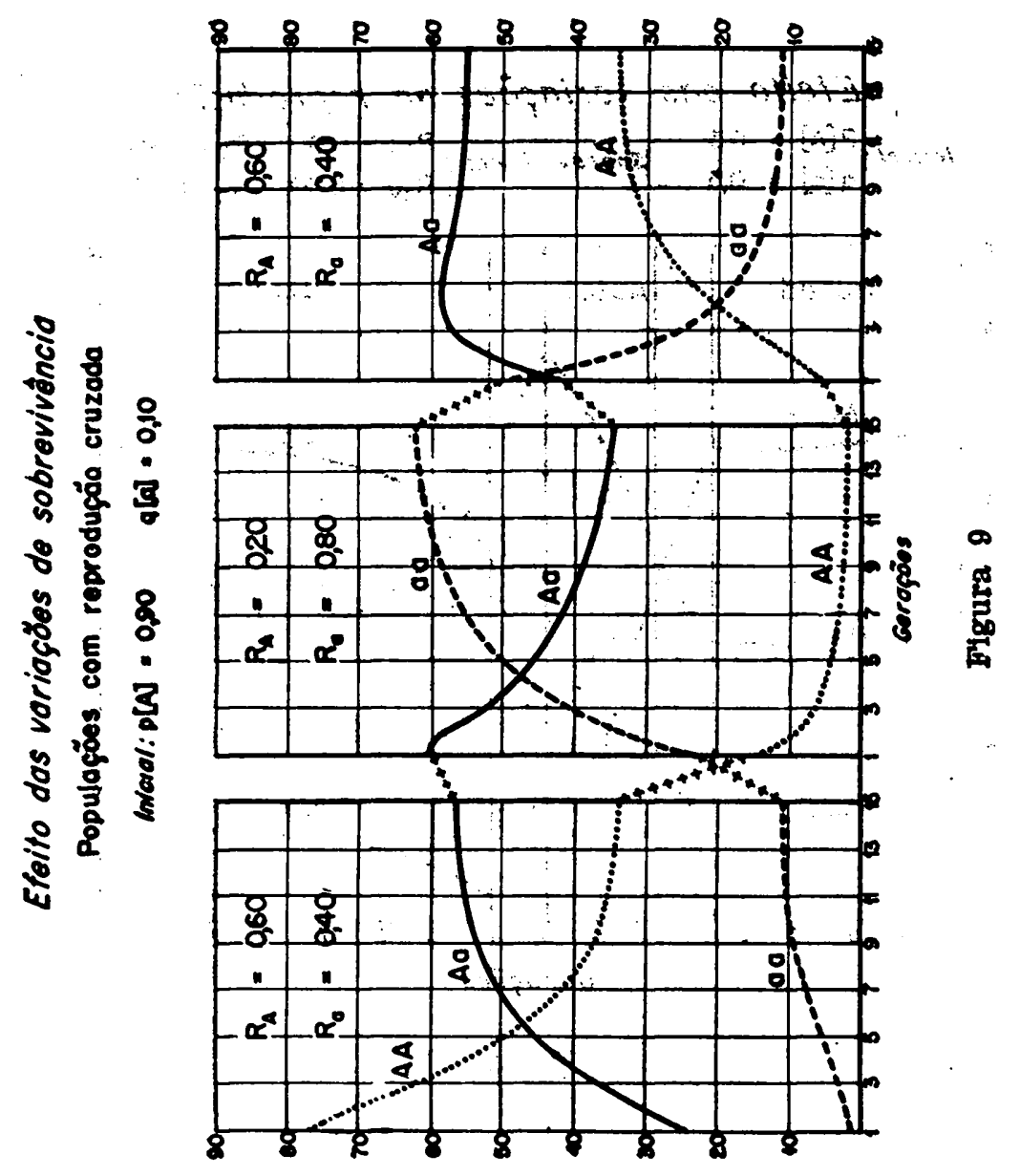


Efoito das variogöes na reprodugä́

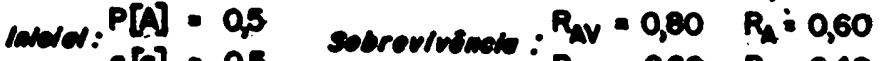

$q[a]=0,5$ sobrovinimals: $R_{\text {eV }}=0,50 \quad R_{Q}=0,40$

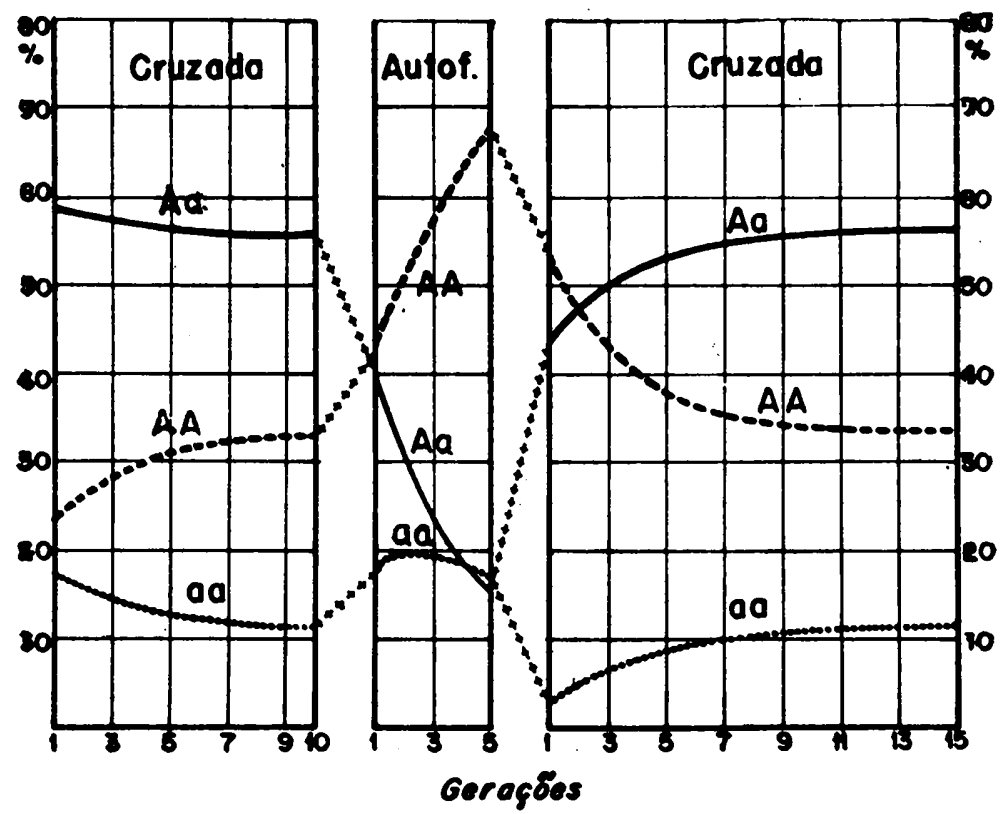

Figura 10 